\title{
Bioinformática Estrutural de Proteínas Modificadas por Eventos de Splicing Alternativo
}

\author{
Elza Helena Andrade Barbosa Durham
}

TESE APRESENTADA AO PROGRAMA INTERUNIDADES EM BIOINFORMÁTICA DA UNIVERSIDADE DE SÃO PAULO PARA A OBTENÇÃO DO TÍTULO DE DOUTOR EM CIÊNCIAS

\author{
Área de concentração: Bioinformática \\ Orientador: Dr. Sandro José de Souza \\ Co-orientador: Prof. Dr. Richard Charles Garratt
}

Durante a elaboração desse trabalho a autora recebeu apoio financeiro da CAPES

São Paulo, 10 de dezembro de 2007 




\section{Dedico essa tese \\ à toda minha família.}

Antes de mais nada, fica estabelecido que ninguém vai tirar o meu bom humor. (Fernando Sabino in Obra Reunida, Vol. III) 


\section{Agradecimentos}

Gostaria de agradecer ao meu orientador Sandro de Souza pelo apoio na minha vinda à São Paulo e pela oportunidade de trabalhar em seu laboratório.

Ao meu co-orientador Richard Garratt pela paciência e pelas discussões sobre estruturas protéicas.

Ao meu amigo Lars Juhl Jensen (EMBL) pela ajuda na manipulação dos resultados e análises estatísticas.

Aos meus amigos do Laboratório de Biologia Computacional.

Ao programa de pós- graduação em Bioinformática e seus funcionários.

À CAPES pela bolsa de doutorado.

Em especial, à minha família, especialmente meu marido e filho que estiveram tão perto de mim durante essa tese, me dando todo o carinho e apoio necessários. 



\section{Resumo}

Esse trabalho apresenta um estudo em larga-escala das características estruturais de isoformas de splicing alternativo utilizando ferramentas de bioinformática. Com o intuito de relacionar sequências de nucleotídeo-proteínas e realizar as análises estruturais, um pipeline a fim de associar os eventos de splicing alternativo detectados em sequências nucleotídicas com as sequências de estruturas protéicas disponibilizadas no banco de dados Protein Data Bank (PDB).

Após localizar exatamente o evento de splicing alternativo na estrutura protéica, as seguintes características das estruturas associadas ao evento de splicing alternativo foram analisadas: estruturas secundárias, funcionalidade/exposição ao solvente, sítios de ligação proteína-ligante, domínios estruturais, distância espacial entre bordas de eventos de splicing alternativo e interações inter-residuais.

Pudemos verificar que as bordas dos eventos de splicing alternativo possuem comportamentos distintos das regiões de splicing alternativo, estando mais associadas a modificações biofísicas, apresentando uma tendência a localizarem-se em estruturas secundárias de volta e mais rígidas/expostas ao solvente. As regiões de splicing alternativo não apresentaram essas tendências e não mostraram diferença de comportamento estrutural em relação a outras regiões da mesma proteína nas análises das interações proteína-ligante, na distância espacial entre as bordas de eventos e na interação inter-residual, reforçando a hipótese levantada por outros trabalhos de que não ocorrem modificações estruturais comuns as isoformas do splicing alternativo ou elas são muito sutis, de difícil detecção. 


\section{Abstract}

In this work, we performed large-scale analyses about strutuctural features of alternative splicing variants using bioinformatics tools. In order to do that, we implemented a pipeline that connects alternative splicing events with the sequences of protein structures disposable on Protein Data Bank (PDB). The pipeline maps the location of alternative splicing events in protein structures and analyses the following features: secondary structure, funcionality/solvent exposure, interaction between ligand-protein, structural domains, spatial distance between alternative splicing boundaries and inter-residual interactions.

We verified that the alternative splicing boundaries have a greater tendency to be associated with biophysical modifications, as secondary structure and solvent exposure, than the alternative splicing regions. Therefore, mostly, alternative splicing regions could also not be statistically associated with strucutral features as ligand-protein interactions, spatial distance between alternative splicing boundaries and inter-residual interaction analysis.

Our results suggest that the structural features of alternative splicing variants are only fine-tuning protein structures, being very difficult to detect and/or the variants created by alternative splicing do not have structural features in common with each other. 


\section{Sumário}

1.Introdução - Moléculas Biológicas

$1.1 \quad$ DNA

Projetos Genoma 2

1.2 RNA

1.2.1 Processamento e edição do RNAm (splicing) 4

Bordas exon-íntron $\quad 6$

Complexo Protéico (spliceossoma) 8

Acurácia no reconhecimento das bordas exon-íntron $\quad 10$

$\begin{array}{lll}\text { 1.2.2 Splicing Alternativo } & 11\end{array}$

Detecção de eventos de AS em larga-escala 14

Regulação da expressão gênica 15

Funcionalidade das sequências geradas pelo mecanismo

de splicing alternativo 15

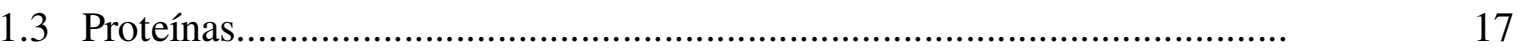

1.3.1 Estrutura de Proteínas 17

$\begin{array}{ll}\text { Estruturas Secundárias } & 18\end{array}$

Classificação estrutural das proteínas 20

Enovelamento 23

Obtenção de estruturas protéicas e

estudos em larga-escala 23

1.3.2 Splicing Alternativo e Estrutura de Proteínas 25

2.Objetivos 


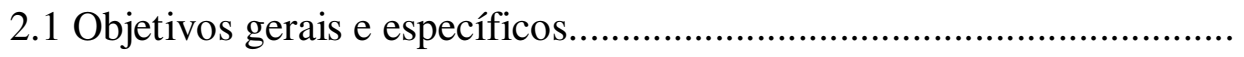

3.Métodos

3.1 Detecção de casos de splicing alternativo.......................................... 32

Protein Data Bank 35

Alinhamento proteína X splicing alternativo 35

Relocalização das bordas genômicas de splicing alternativo a partir dos resultados do alinhamento 39

Retirada da redundância do PDB 42

Representação esquemática do pipeline 47

4.Resultados

4.1 Frequência do evento de AS de acordo com seu tamanho 51

4.2 Distribuição de estruturas secundárias $\quad 58$

4.3 Complexidade de estruturas secundárias $\quad 64$

4.4 Frequência de eventos de AS em domínios estruturais 71

4.5 Frequência de eventos de AS em aminoácidos funcionais 76

4.6 Distância espacial entre o evento de AS e os sítios de ligação 80

4.7 Distância espacial entre resíduos flanqueadores do evento de AS 86

4.8 Interações inter-residuais no trecho correspondente ao evento de AS 91

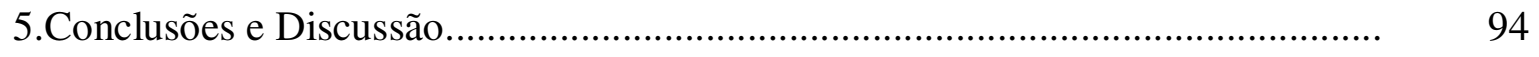

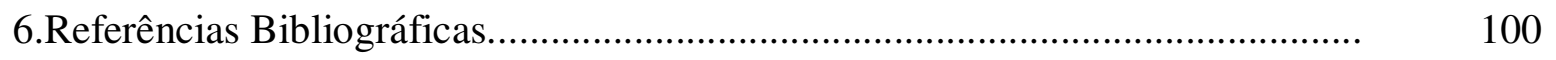




\section{Lista de Abreviaturas/Sinônimos}

AS (alternative splicing) $=$ splicing alternativo

AU (alternative usage of splice sites) = uso alternative dos sítios de splice

Branch site $=$ ponto do sítio de ramificação

$\mathrm{cDNA}=$ DNA complementar

DNA (desoxiribonucleic acid) = ácido desoxirribonucléico

ES $($ exon skipping $)=$ retirada de exon

ESE (exonic splicing enhancer) $=$ acentuadores de splicing exônico

ESS (exonic splicing silencer $)=$ silenciador de splicing exônico

EST(s) (expressed sequence tags) = marcadores de seqüências expressas

Full-length $=$ transcrito inteiro de RNAm

Indels $=$ inserções e deleções ocorrendo na mesma sequência

ISE (intronic splicing enhancer) $=$ acentuadores de splicing intrônico

ISS (intronic splicing silencer) = silenciador de splicing intrônico

$\mathrm{IR}($ intron retention $)=$ retenção de íntron

$\log =$ logarítmo

log-odd = logarítmo de razão de probabilidades

$\mathrm{pb}=$ pares de bases

RNA (ribonucleic acid) = ácido ribonucléico

SAGE (Series Analysis of Gene Expression) = Análise Serial da Expressão Gênica

SNPs $($ Single Nucleotide Polymorphism $)$ = Polimorfismo de um só nucleotídeo

MPSS (Massive Parallel Sequence System) = sistema de sequenciamento paralelo em

massa 


\section{Lista de Figuras}

Figura 1.2.1-1 Esquema das modificações sequenciais do DNA ao RNAm.

Figura 1.2.1-2 Esquema das bordas exon-intron no DNA (adaptado).

Figura 1.2.1-3. Representação da montagem do complexo protéico do spliceossoma e do mecanismo de splicing do pré-RNAm, transformando-o em RNAm maduro.

Figura 1.2.2-1 Representação dos tipos de eventos de splicing alternativo. Considerando-se uma sequëncia modelo de RNAm em que os exons (em preto) vão ser modificados por diferentes eventos de splicing alternativo.

Figura 1.3.1-1 - Esquema dos tipos de estrutura protéica (adaptado).

Figura 3.1.1. Demonstração esquemática dos casos de inserção e deleção detectados a partir do alinhamento entre candidatos de splicing alternativo e sequências derivadas de estruturas protéicas. As regiões em preto circundadas correspondem à região flanqueadora (aminoácidos logo antes ou depois da região de splicing alternativo). A. Região em cinza corresponde a uma deleção na sequência alinhada em relação ao PDB, o qual possui toda a informação estrutural dessa região. A região com textura corresponde a região da sequência nucleotídica cujo correspondente é o trecho em cinza do PDB, que inclui a informação da região flanqueadora. B. Região em cinza corresponde a uma inserção na sequência alinhada 
em relação ao PDB. A região com textura corresponde a uma região inexistente no PDB, em que somente temos a informação da região flanqueadora.

Figura 3.1.2. Demonstração esquemática na estrutura protéica dos casos de deleção (A) e inserção (B) detectados a partir do alinhamento entre candidatos de splicing alternativo e sequências derivadas de estruturas protéicas. Os círculos correspondem às regiões flanqueadoras.

Figura 3.1.3. Frequência de eventos de AS mapeados a estruturas protéicas de acordo com o tamanho do evento para intervalos de 10 aminoácidos em: A. inserções; B. Deleções C. Indels. Barras cinzas correspondem ao dado completo e pretas correspondem ao dado sem redundância (cluster_90\% do PDB).

Figura 3.1.4. Representação esquemática do pipeline.

Figura 4.1.1 Gráficos log-log da frequência do tamanho dos eventos de AS. A. Uso alternativo dos sítios de splice (AU); B. Retirada de exons (ES); C. Retenção de íntrons (IR); D. Soma da frequência dos eventos anteriores (AU + ES + IR).

Figura 4.1.2 Gráfico log-log da frequência de casos de splicing alternativo de acordo com o tamanho do splicing (figura adaptada de Wang (2005)]).

Figura 4.1.3. A. Frequência dos tamanhos de eventos de AS mapeados a estruturas protéicas; B. Gráfico log-log da frequência dos tamanhos de eventos de AS mapeados a 
estruturas protéicas (ambos os gráficos descrevem casos com mais de 90\% de identidade no alinhamento, como descrito nos métodos dessa tese) .

Figura 4.2.1. Frequência de eventos de AS mapeados a estruturas protéicas de acordo com o tamanho do evento para intervalos de 10 aminoácidos em: A. inserções; B. Deleções C. Indels. Barras cinzas correspondem ao dado completo e pretas correspondem ao dado sem redundância (cluster_90\% do PDB).

Figura 4.3.2 - Frequência (em porcentagem) das estruturas secundárias encontradas nas bordas das regiões de: A. deleções; B. Inserções e C. indels. Barras cinzas são as bordas de AS e barras pretas são as proteínas não-redundantes relacionadas a AS agrupadas (cluster_pdb_90\%).

Figura 4.4.1 - A. Ilustração do trecho deletado na estrutura protéica. B. Demonstração da sequência correspondente ao trecho deletado (Seq_PDB) com 17 amino ácidos, a estrutura secundária que esse trecho possui (Seq_Est_Sec) com 17 estruturas secundárias mapeadas e a simplificação dessa estrutura para a medida de diversidade de estruturas secundárias na proteína (Seq_Complexidade) agora com 3 estruturas.

Figura 4.4.2 - Gráfico log da combinação de estruturas secundárias de acordo com o tamanho da região A. para a classificação do PDB e B. para a classificação do DSSP. 
Figura 4.4.3 - Visualização da combinação de estruturas secundárias (DSSP / STRIDE) para regiões de 20 amino ácidos com A. 3 combinações de estrutura secundária (transtirretina (1bz8_A)) e B. 15 combinações de estrutura secundária (complexo antitrombina - trombina - heparina (1tb6_I)).

Figura 4.4.4 - Frequência da quantidade de estruturas secundárias normalizada pelo tamanho da deleção em: A. PDB e B. STRIDE.

Figura 4.7.1. Frequência das menores distâncias proteína-ligante para: A. o trecho de AS; B. toda a proteína.

Figura 4.7.2. Gráfico da quantidade de proteínas agrupadas (cluster_pdb_90\%) de acordo com a distância normalizada do sítio de ligação. As barras cinzas demonstram a diferença de cada distância em relação a média (quadrados em preto).

Figura 4.8.1. - Ilustração da distância espacial das bordas (região flanqueadora) representadas por círculos nas regiões de deleção em estruturas protéicas.

Figura 4.8.2. - Frequência da distância espacial das bordas (região flanqueadora) nas regiões de deleção em estruturas protéicas.

Figura 4.8.3. Gráfico da distribuição das distâncias espaciais de acordo com o tamanho da região spliceada (distância sequencial). Barras cinzas representam as distâncias dos dados 
de AS. Pontos e linhas em preto mostram, respectivamente, as médias e suas variações (um desvio padrão) da mesma distância sequencial no resto da proteína.

Figura 4.9.1 - Distribuição da quantidade normalizada de interações inter-residuais de acordo com a distância sequencial. Barras em preto, a quantidade média de interações do PDB e barras cinzas a quantidade média de interações no trecho deletado de splicing alternativo.

Figura 4.9.2 - Gráfico da quantidade de proteínas agrupadas (cluster_90\%) de acordo com a distribuição normalizada da quantidade de interações inter-residuais. As barras cinzas demonstram a diferença de cada distância em relação a média (quadrados em preto). 


\section{Lista de Tabelas}

Tabela 1.3.1.-3 Nomenclatura utilizada para classificação de proteínas sequencial e estruturalmente.

Tabela 1.3.1.1-1 - Resumo das características das estruturas experimentais de proteínas modificadas por splicing alternativo (adaptado de Stetefeld (2005) e Romero (2006)). As referências para cada estrutura são: \{1\} [ Hymowitz (2003)]; \{2\} [Oakley (2001)]; \{3\} [Peneff (2001)]; \{4\} [Fiegen (2004)]; \{5\} [Lee (2003)]; \{6\} [Stetefeld (2004)] e \{7\} [Garcia (2004)].

Tabela 4.3.1 - Descrição das estruturas secundárias encontradas $(\mathrm{C}=$ coil, $\mathrm{E}=$ folha e $\mathrm{H}=$ hélice) nas bordas das regiões de inserção, deleção e indels. O total _PDB_nr foi calculado a partir da quantidade de aminoácidos de proteínas relacionadas a AS (somente aquelas com o maior tamanho de cada cluster_pdb_90\%) encontradas no PDB. A análise estatística foi realizada utilizando o teste $\chi^{2}$.

Tabela 4.5.1 - Distribuição das classes de domínios estruturais relacionados a eventos de AS. Entre parênteses a proporção, em itálico o p-value do teste de Fisher comparado ao total de domínios humanos não-redundantes do CATH.

Tabela 4.5.2 - Distribuição das arquiteturas de domínios estruturais relacionados a eventos de AS. Entre parênteses a proporção, em itálico o p-value do teste de Fisher comparado ao 
dado total humano do Cath (só são mostrados aqueles casos em que a frequência é maior que $5 \%$ em pelo menos um dos tipos inserção, deleção ou indel).

Tabela 4.6.1 - Frequência dos aminoácidos agrupados (cluster_pdb_90\%) das bordas de inserções, deleções e indels com diferentes características biofísicas (exposição e flexibilidade) dados pelo programa ProfBval. 


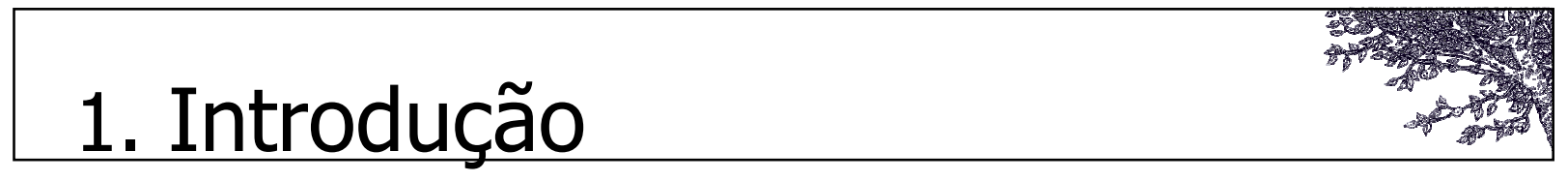




\section{Introdução - Moléculas Biológicas}

\subsection{DNA}

A descoberta de um elemento ativo na perpetuação da informação genética de todos os organismos iniciou-se com experimentos do monge austríaco Gregor Mendel (18221884), envolvendo cruzamento entre ervilhas de diferentes cores. Dos seus experimentos, foi possível observar que diferentes fatores (genes) resultam em vários pares de características contrastantes (fenótipos) e tem possíveis formas alternativas (alelos). Com a revisão de seus estudos por outros pesquisadores, a definição de gene foi modificada. Atualmente, um gene pode ser definido como um segmento de DNA localizado no cromossomo que, na maioria das vezes, está associada a regiões regulatórias (promotores) [Pearson (2006)]. Outros estudos bioquímicos ajudaram a compreender como os genes controlam os fenótipos nos organismos. Um deles foi a hipótese tetranucleotídica, na qual o gene seria uma sequência formada somente pela combinação de quatro bases, que mais tarde foram descritas como: adenina (A), timina (T), citosina (C) e guanina (G). As estruturas químicas dessas bases foram resolvidas na mesma época da formulação da hipótese tetranucleotídica (Levinne [1951]), e como resultado da associação das mesmas com a desoxirribose e o fosfato foram descobertos os nucleotídeos. Esses nucleotídeos, ordenados, originarão uma sequência DNA, também conhecido como "código genético". Nessa mesma época, Chargaff [Chargaff (1951)] descobriu que as proporções de A e T eram sempre iguais, assim como as de C e G. Até que foi possível visualizar a informação 
genética em um espaço tridimensional, a partir da estrutura cristalográfica do DNA. Nela foi visto que duas cadeias antiparalelas complementares estão pareadas (A e T, C e G) em uma estrutura periódica de dupla-hélice voltada para a direita (right-handed), com cerca de 10 nucleotídeos por volta de hélice [Watson (1953)]. As implicações da descoberta da estrutura do DNA foram imediatamente vistas no modo de replicação e de transferência de informação para os genes.

\section{A busca pelo código genético (Projetos Genoma)}

Atualmente, sabemos que diferentes códigos genéticos determinam as características de cada organismo, independente do tecido do qual ele foi retirado ou da idade do mesmo, do seu estado nutricional ou qualquer outro fator ambiental. Para determinar quais seriam as diferenças entre os organismos determinadas pelo código genético, em 1977 o bacteriófago $\Phi-X 174$ [Sanger (1977)] foi o primeiro fago a ter seu código genético completamente sequenciado, o que atualmente conhecemos como Projeto Genoma (PG). Nesse trabalho foi utilizada a técnica de shotgun, em que o genoma é quebrado em muitos pedaços, sendo cada um deles sequenciado separadamente e depois submetidos a um algoritmo que permite unir toda essa informação. Em 1995, o uso de sequenciadores automatizados e métodos computacionais que utilizam a informação de grandes regiões do genoma (contigs) para reconstruí-lo, permitiram o sequenciamento do primeiro animal (Haemophilus influenzae) [Fleischmann (1995)] e estimulou a formação de grupos de pesquisadores para o sequenciamento do genoma humano (Projeto Genoma Humano - PGH). Dois grupos foram formados paralelamente (um público [Lander (2001)]

e outro privado [Venter (2001)]) e, em ambos, o genoma foi clonado e foram obtidas 
"bibliotecas" de DNA que são organizadas para formar uma sequência consenso com cerca de 3 bilhões de pares de bases.

A principal finalidade dos PGs é determinar a exata sequência de DNA dos organismos a fim de estudá-la de forma aprofundada, determinando a quantidade, localização e função de cada gene. Com essa informação, espera-se também controlar e prevenir doenças. A comparação entre genomas de diferentes organismos permite ampliar o conhecimento sobre semelhanças e diferenças genéticas. Apesar de todos os cromossomos

humanos terem sido completamente sequenciados em 2006 [Gregory (2006)], finalizando o PGH, ainda não foi possível determinar a quantidade exata de genes em nosso organismo. Estimativas para a quantidade de genes variam entre 20-75.000 genes [Kan (2001), Modrek (2001), Brett (2002), Lander (2001), Venter (2001), Modrek (2002)], um número muito inferior aos 100.000 genes esperados antes do PGH [Sharp (1994)].

\section{2. $R N A$}

O fluxo de informação dentro das células eucarióticas, como a passagem da informação do DNA para RNA e, posteriormente, para as proteínas foi descrito por Crick em 1970 [Crick (1970)]. Os RNAs também são formados por quatro nucleotídeos (lembrando que a timina (T) é substituída pela uracila (U)) e apresentam-se em sua maioria como uma molécula de fita simples com estrutura indefinida. Brachet [Brachet (1956)] mostrou que o RNA possui um papel fundamental na síntese protéica, sendo que a síntese não é direcionada diretamente do DNA em eucariotos, pois o DNA (localizado no núcleo celular) e os ribossomos (localizados no citoplasma) nunca estão em contato. O complexo 
mecanismo de transcrição eucariótica, onde é transmitida a informação do DNA para o RNA, utiliza uma série de enzimas. As enzimas polimerases de RNA com diferentes funções (pol I, pol II e pol III) participam na síntese protéica, assim como vários tipos de RNA: RNA ribossomal (RNAr), RNA de transferência (RNAt) e RNA mensageiro (RNAm). Somente o RNAm será traduzido em proteínas, sendo que os outros RNAs não são codificados (também conhecidos como RNAs não codificantes ou ncRNAs). Os ncRNAs incluem outros elementos como: smRNA (RNA small nuclear), miRNA (micro RNA), eRNA (RNA eferência) e pRNA (RNA promotor) que possuem diversos papéis na regulação da transcrição e expressão gênica, por exemplo, como inibidor da expressão de um gene alvo através da complementação reversa das porções de outros RNAms (miRNAs) ou realizando modificações químicas como metilações em RNA ribossômicos (smRNAs).

\subsubsection{Processamento e edição do RNAm (splicing)}

Durante a transcrição, o RNAm é processado e transportado, antes da tradução de sua sequência nucleotídica em aminoácidos e, consequentemente, proteínas. A complexidade desses processos é maior em eucariotos do que em bactérias e archea, devido a quantidade de proteínas requeridas, inclusive, para o transporte dessas moléculas de RNAm dentro da célula. Em 1977 foi descoberto que os genes de eucariotos são separados em diversos segmentos ao longo da molécula de RNAm [Berget (1977), Chow (1977)] e um mecanismo especial estaria sendo utilizado para reconhecer e retirar alguns desses pedaços. O mecanismo de splicing, que pode ser traduzido como "separação em pedaços",

ocorre logo após a transcrição e é utilizado em eucariotos para a geração de RNAms 
maduros. Para isso, ocorre o processamento e a edição dos RNAms precursores (préRNAms). Os pré-RNAms são sequências de RNAm de fita simples e vida curta que, quando editados, removem em média mais que $90 \%$ das suas sequências (introns) e unem os $10 \%$ restantes (exons) formando o RNAm maduro. A região 5' UTR (untranslated region) começa no primeiro nucleotídeo do sítio de início da transcrição (TSS transcription start site) e termina logo antes do códon de iniciação da região codificante. Ele normalmente contém um sítio de ligação do ribossomo, conhecida em bactérias como sequência Shine-Delgarno e outras sequências regulatórias que promovem o início da tradução. A região 3' UTR vem logo após a região codificante e comumente contém: um sinal de poliadenilação, marcando o local de clivagem do transcrito cerca de 30 pares de bases após esse sinal; sítios de ligação de selenocisteínas (SECIS), proteínas que direcionam o ribossomo na tradução e podem atuar como códons de parada ou nucleotídeos adenina/uridina que podem estabilizar ou desestabilizar o RNAm dependendo da proteína a qual ele está ligado (AU rich elements - AREs)) . Nesses pré-RNAms ocorre o capeamento da porção 5', em que a guanina é adicionada usando uma ligação 5',5-trifosfato. Quase simultaneamente, ocorre a poliadenilação da porção 3' da mesma sequência, sendo que ambas modificações permanecem no RNAm maduro e são críticas para o reconhecimento, ligação do RNAm ao ribossomo e também como proteção contra a degradação do RNAm maduro por exonucleases durante o transporte dessa molécula do núcleo para o citoplasma. 
DNA

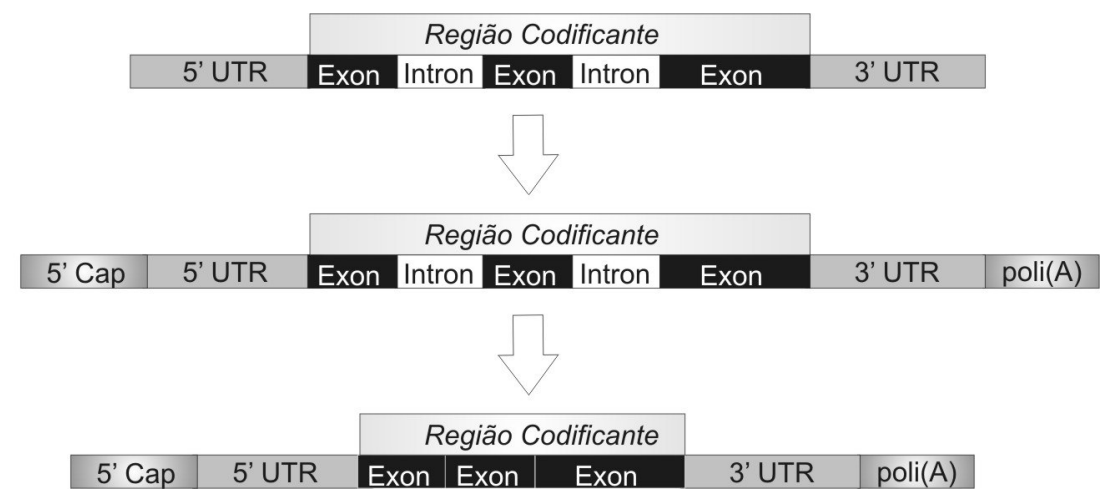

Figura 1.2.1-1 Esquema das modificações sequenciais do DNA ao RNAm.

\section{Bordas exon-intron}

A maquinaria de splicing reconhece especificamente as barreiras exon-intron (ou bordas de splice), removendo a sequência genômica entre eles e, consequentemente, unindo os exons restantes [Newman (1994), Nilsen (2003)]. Essas barreiras, também conhecidas como sítios de splice, são comumente definidas por seqüências altamente conservadas que permitem a correta identificação dos mesmos. Os dinucleotídeos GT e AG (e suas variações) localizados na posição 5' e 3' do íntron são chamados, respectivamente, de sítios doador e aceitador de splice [Senapathy (1990), Mount (2000)]. 


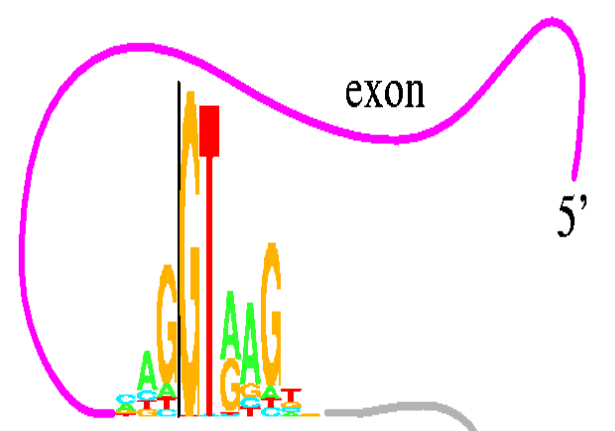

(5')Doador

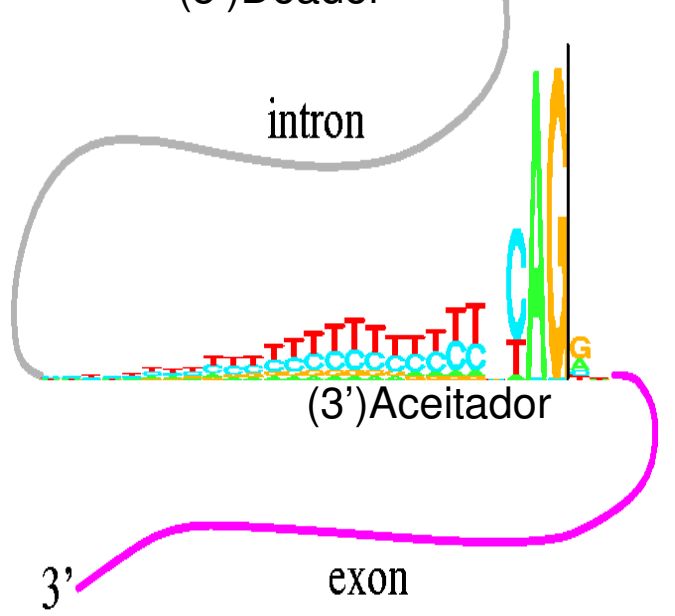

Figura 1.2.1-2 Esquema das bordas exon-intron no DNA (adaptado de http://www.ccrnp.ncifcrf.gov/ toms/gallery/SequenceLogoSculpture.gif).

Os sítios de splice podem ser classificados em cinco tipos principais: autêntico, críptico, mutante, pseudo e alternativo [Roca (2003)]. Os sítios autênticos são aqueles que originam uma seqüência de RNAm pelo reconhecimento das bordas de splicing conservadas. Os sítios “crípticos” são as seqüências que são codificadas porque houve uma mutação em outra região da seqüência genômica, fazendo com que o local da mutação seja reconhecido como um sítio "autêntico" de splicing. Esses sítios de splice possuem uma freqüência de distribuição similar em exons e introns e o spliceossoma passa a reconhecêlos, codificando um RNAm estendido ou diminuído em relação ao que seria transcrito pelos sítios autênticos. Os sítios mutantes são aqueles em que as mutações no sítios de splice 
autênticos afetam a eficiência do splicing nesse sítio. Os pseudo sítios são aqueles em que os motivos consenso dos sítios de splice são degenerados e os sítios alternativos de splice são aqueles que ocorrem naturalmente em regiões próximas ao sítio autêntico de splice e podem ou não ser utilizados pela maquinaria de splicing para a criação de outros transcritos.

Além desses sítios, outras características das sequências ajudam a identificar as bordas exon-íntron, como as quantidade de purinas e pirimidinas ao longo do sítio do ponto de ramificação (branch site) e a conformação do RNAm, que poderá influenciar a acessibilidade aos sítios de splice por outras proteínas [Zhuang (1989), Balvay (1993)].

\section{Complexo protéico de splicing (Spliceossoma)}

As bordas exon-intron são reconhecidas por um aparato formado por um grande complexo protéico chamado de spliceossoma. Esse complexo permite a proximidade entre as sequências consenso das bordas antes de qualquer outra reação química, explicando como uma modificação dos sítios de splice $5^{\prime} / 3^{\prime}$ pode impedir que haja a retirada da região associada a esses sítios. O spliceossoma é formado por proteínas e pequenas ribonucleoproteínas, moléculas de RNA restritas ao núcleo celular também chamadas de snRNPs (small nuclear ribonucleoproteins). Cada snRNP contém um ou dois snRNA (small nuclear RNA) e de 3 a 20 proteínas associadas. Aqueles snRNPs envolvidos no splicing foram nomeados de acordo com o snRNA que elas representam (U1, U2, U4, U5 e U6).

O processo de montagem do complexo de spliceossoma está explicado aqui de forma resumida. Como pode ser visto na figura a seguir, o snRNP U1 se liga ao sítio de 
splice $5^{\prime}$ e U2 se liga ao sítio do ponto de ramificação (branch site) formando o complexo A. O complexo B1 é formado pela interação entre U5/ U4/ U6. Eles se ligam ao complexo A sendo que U5 se liga ao sítio 3’ e U6 liga-se a U2. No complexo B2, U5 muda sua posição de exon para intron e U6 se liga ao sítio de splice $5^{\prime}$. No complexo C, U1 e U4 são liberados, U6/U2 catalizam a transesterificação enquanto U5 se liga ao exon no sítio de splice $3^{\prime}$.

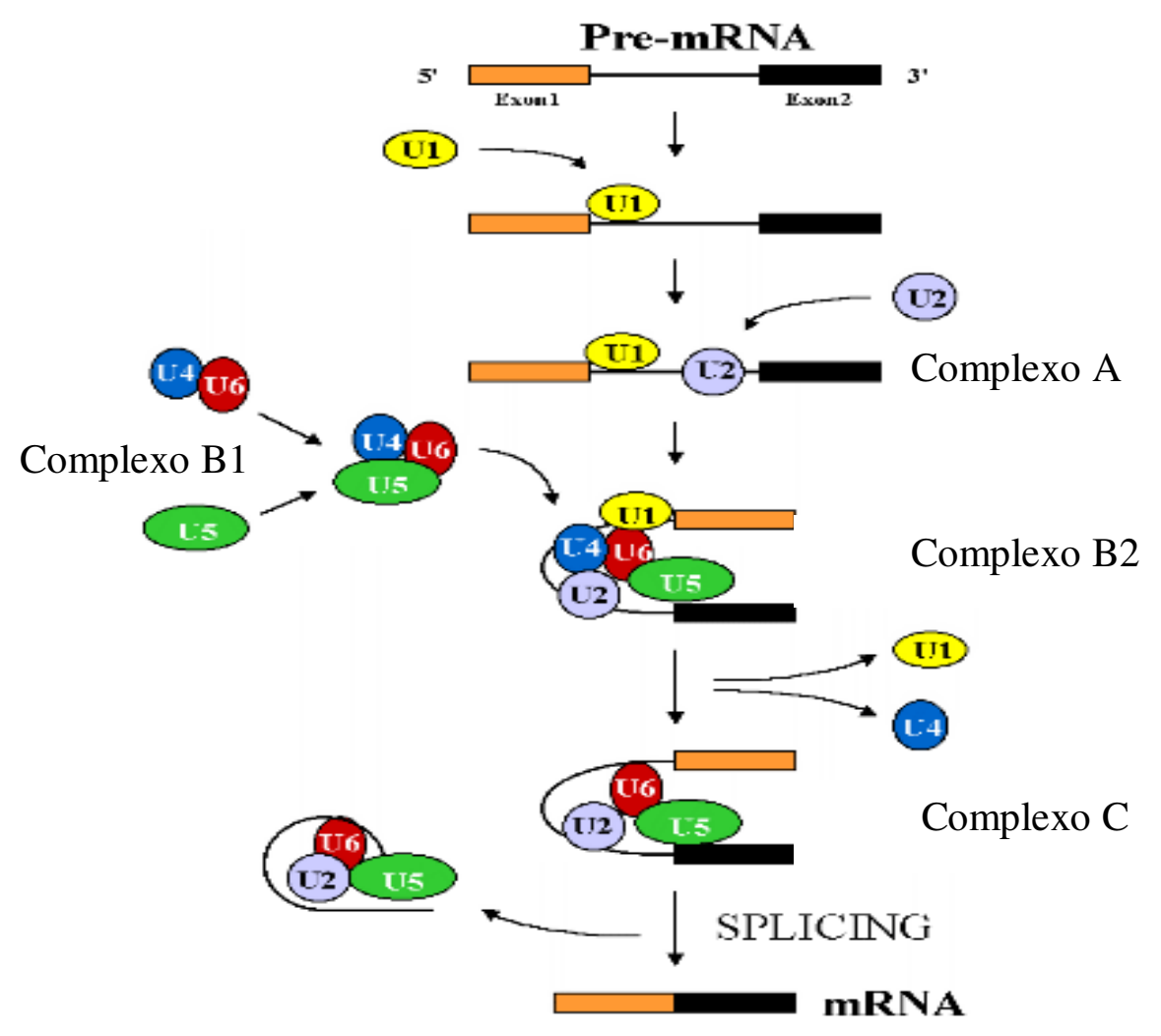

Figura 1.2.1-3. Representação da montagem do complexo protéico do spliceossoma e do mecanismo de splicing do pré-RNAm, transformando-o em RNAm maduro.

Durante a formação do complexo $\mathrm{C}$, o splicing pode ser quimicamente resumido a dois processos de transesterificação entre o RNA e os nucleotídeos. No primeiro, a hidroxila 2' de um ponto de ramificação (branch point) específico no intron faz um ataque 
nucleofílico ao primeiro nucleotídeo do mesmo intron (sítio de splice 5'), formando um intermediário de laço (lariato). Em seguida, a hidroxila 3' da parte liberada do exon faz um ataque nucleofílico ao último nucleotídeo do intron (sítio de splice 3'), unindo os exons e liberando o laço do intron.

\section{Acurácia no reconhecimento dos sítios de splice}

Apesar dos sítios de splice terem sido previamente determinados com grande detalhamento, ainda não se compreende totalmente como ocorre o mecanismo de splicing. O não reconhecimento dos sítios corretos de splice pode ocorrer devido a degeneração do dinucleotídeo GT na borda 5’ do intron ou devido a degeneração do dinucleotídeo AT na borda 3' do intron. Além disso, variações sobre a presença de um trato degenerado rico em pirimidinas (Y) e o sítio do ponto de ramificação, onde ocorre o ataque nucleofílico pela maquinaria de splicing, devem influenciar o reconhecimento desse local pela maquinaria.

Como resultado, é difícil predizer acuradamente in silico padrões de splicing somente a partir de sequências genômicas, sendo que o reconhecimento acurado dos sítios de splice in vivo é o resultado de um mecanismo combinatorial regulatório [Reed (2000)]. Além disso, elementos sequenciais adicionais localizados em exons ou introns adjacentes podem ajudar no reconhecimento dos sítios de splice, através da ligação de proteínas regulatórias (ricas em serina e arginina $(\mathrm{SR})$ ). Essas proteínas SR, responsáveis por recrutar os snRNPs para o reconhecimento dos sítios de splice, também podem se ligar a subsequências curtas promotoras ou silenciadoras localizadas em exons (ESEs ou ESSs) ou em introns (ISEs ou ISSs). Estudos recentes mostram que mutações associadas a doenças genéticas nos exons podem ser causadas pela inativação de ESEs [Blencowe (2000)]. É 
importante ressaltar que, além das modificações ao redor das bordas de splice, mutações pontuais nessas bordas podem ser encontrados em pelo menos $15 \%$ dos genes relacionados a doenças humanas, podendo esse número chegar a 50\% [Teraoka (1999), Ars (2000), Cooper (2002)].

\subsubsection{Splicing Alternativo}

Em 1941, os pesquisadores Beadle e Tatum [Beadle (1941)] demostraram que um gene corresponde a uma proteína através da correspondência entre uma mutação no DNA e a ausência de determinada enzima. Associando esse axioma a diferença de complexidade entre organismos, esperava-se que quanto maior a complexidade do organismo, maior seria a quantidade de genes e, consequentemente, a quantidade de proteínas. Esse axioma só foi quebrado após a conclusão de alguns PGs, quando a comparação entre as quantidades de genes em diferentes organismos não se mostrou proporcional a complexidade de cada um deles. Um exemplo é semelhança entre a quantidade média de genes preditos em arroz (55.000) [International Rice Genome Sequencing Project (2005)] e em humanos (30.000) [Lander(2001), Venter (2001)].

Uma explicação plausível para a ausência de correlação entre a quantidade de genes e a complexidade dos organismos foi dada pelo mecanismo de splicing alternativo. Esse mecanismo era considerado raro, ocorrendo somente em cerca de $5 \%$ de todos os genes [Sharp (1994)]. Nele, considera-se que a informação estocada nos genes pode ser frequentemente editada de várias maneiras, possibilitando que o mesmo gene origine duas ou mais proteínas. No mecanismo de splicing convencional, os introns são inteiramente 
retirados e os exons unidos para formar o pré-mRNA. No splicing alternativo, inteiros ou parcialmente, nem todos os introns são retirados e ou nem todos os exons são unidos. Como vimos no tópico anterior, mutações nos exons e ao longo da sequência de DNA podem vir a modificar um sítio de splicing convencional, tornando-o um sítio alternativo.

A comparação entre sequiências nucleotídicas permite a classificação das mesmas de acordo com o evento de splicing alternativo que elas representam. Os padrões de edição das sequências podem ser classificadas em:

* Retenção de intron (IR) - em um par de seqüências o intron de uma foi totalmente incluído na outra sequência;

* Uso alternativo dos sítios de splice 5' / 3' (AU) - em um par de seqüências onde o intron de uma sofreu modificações em uma das suas barreiras ou em ambas comparandose a outra seqüência.

* Retirada de Exon (ER) - observando duas seqüências, um exon (ou mais que um) está presente em uma seqüência e ausente na outra.

* Exons mutuamente exclusivos - quando, para um par de sequências, o exon retirado de uma delas está presente na outra (e vice-versa). Esses exons nunca são detectados no mesmo transcrito. 
RNAm

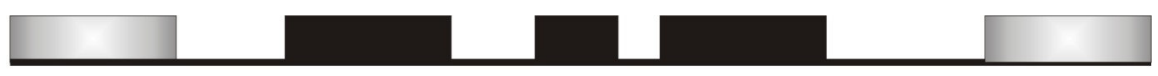

Retirada de Exon
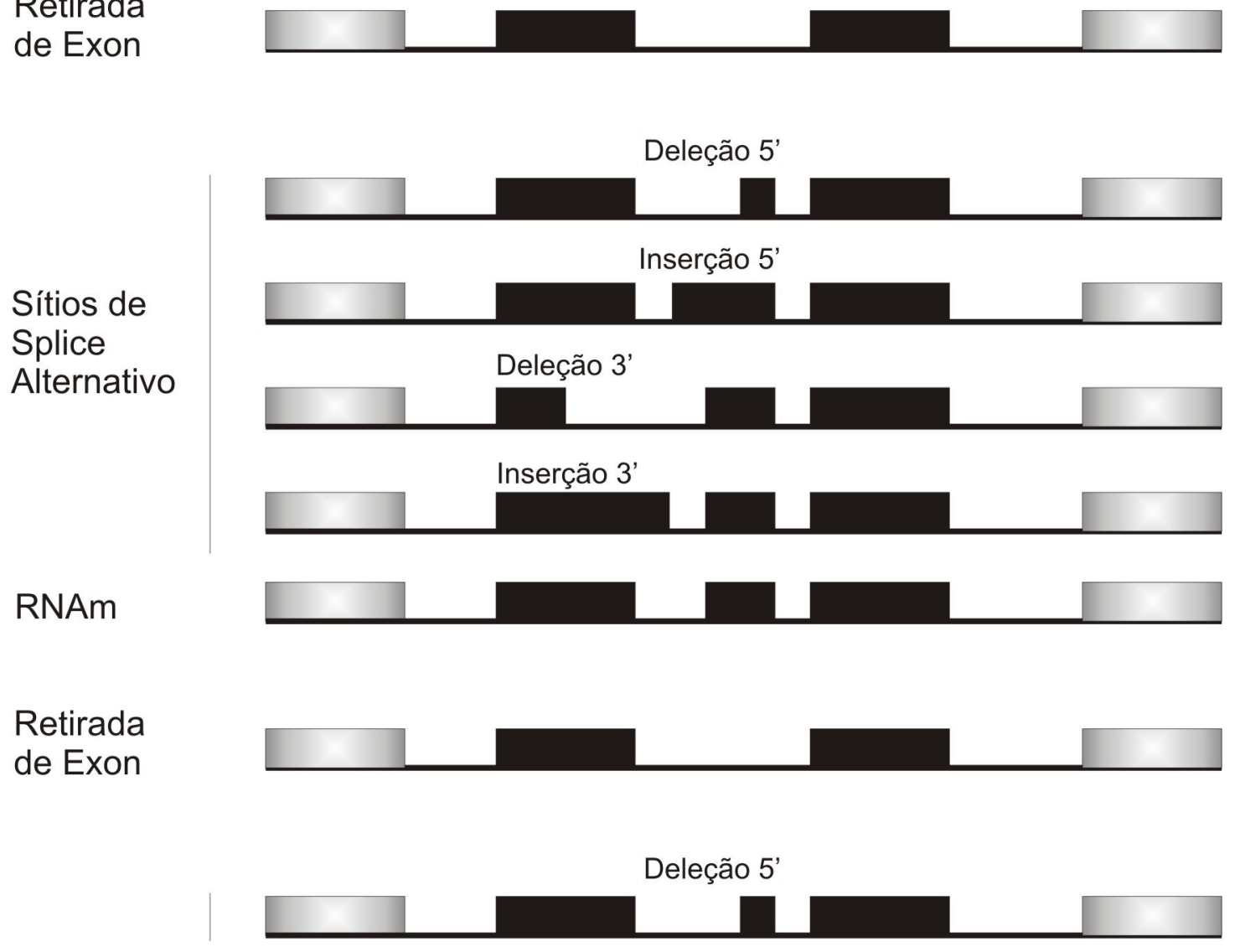

Figura 1.2.2-1 Representação dos tipos de eventos de splicing alternativo. Considerando-se uma sequëncia modelo de RNAm em que os exons (em preto) vão ser modificados por diferentes eventos de splicing alternativo.

Em humanos, estudos de bioinformática estimam que esse mecanismo pode ser utilizado em $35-60 \%$ dos genes, aumentando cerca de 2 a 3 vezes a produção de proteínas. Isso implica também que, para o mesmo gene, proteínas podem ser ativadas com diferentes funções em um ou mais tipos de tecidos (isoformas tecido-específicas). 


\section{Detecção dos eventos de splicing alternativo em larga-escala}

Atualmente, algumas abordagens vêm sendo utilizadas para acessar as diferenças funcionais entre os transcritos de RNAm modificados por splicing alternativo. Das abordagens experimentais, o uso de sequências anti-sense [Mercatante (2000)] e RNA interferência (RNAi) [Cho (2000), Kisielow (2002)] para bloquear um dos variantes têm se mostrado promissora, porém a maioria dos estudos experimentais em larga-escala de variantes têm sido desenvolvidos utilizando a técnica de microarray, que permite identificar e quantificar a expressão relativa das isoformas de splicing alternativo. Abordagens teóricas também vêm sendo utilizadas para estudar em larga-escala os genes e seus transcritos modificados pelo splicing alternativo através da bioinformática (revisado em Woodley [2002]). Através dela são feitas comparações entre sequências de DNA, cDNA, ESTs e transcritos inteiros de RNAm (full-length). Obtidas dos PGs, as comparações entre essas sequências permitem encontrar genes, localizar exons, analisar a expressão gênica dos variantes, mapear SNPs (single nucleotide polymorphism polimorfismos de um nucleotídeo) e detectar casos de splicing alternativo. Essas informações geralmente são organizadas em bancos de dados relacionais para facilitar a manipulação desses dados. Alguns problemas podem ocorrer devido ao depósito de sequências de baixa qualidade, principalmente ESTs. Esse problema pode ser contornado utilizando mais que uma EST representando a mesma região do genoma. Uma amostra da baixa qualidade das ESTs também pode ser observada pela grande quantidade dessas sequências que não são mapeadas ao genoma [Modrek (2001), Heber (2002)]. Para facilitar sua manipulação e tentar evitar a redundância dos dados de sequências eles são agrupados em índices onde cada grupo (cluster), teoricamente, possui todas as sequências do mesmo 
gene. Esses agrupamentos estão disponibilizados em diferentes projetos como, por exemplo, Unigene [Pontius (2003)], Gene Index [Quackenbush (2000)] e STACK [Christoffels [2001]). A comparação das sequências agrupadas no mesmo gene permite a identificação dos variantes de splicing alternativo e dos tipos de eventos em cada gene.

\section{Regulação da expressão gênica}

A regulação da expressão gênica das sequências modificadas por splicing alternativo permite ao organismo controlar quando, como e quantos transcritos são codificados por determinado gene. Essa regulação permite associar a expressão de determinados variantes a tecidos específicos, determinadas etapas do desenvolvimento ou a doenças. Quando a quantidade de transcritos representando determinado gene está aumentada ou diminuída, estes genes são chamados de super-expressos e sub-expressos, respectivamente. Essa super ou sub expressão pode estar associado a algum estado patológico. A análise da expressão gênica é largamente utilizada para detectar genes associadas ao câncer [Cole (1999), Hoos (2001), Xu (2003)]. A regulação da expressão gênica pode ser estudada através de métodos experimentais citados anteriormente como ESTs, microarrays, SAGE e MPSS. A bioinformática é utilizada para relacionar as informações sobre a expressão gênica, permitindo a associação da expressão com variantes tecido-específicos ou associados a tumor, por exemplo.

\section{Funcionalidade das sequências relacionadas a eventos de splicing alternativo}

As possíveis modificações nas sequências do RNAm maduro e consequências do splicing alternativo incluem a introdução de códons de parada, mudanças na 5'/3' UTR e 
mudanças na estrutura protéica. Sobre a atividade e funcionalidade dessas seqüências, a maioria dos estudos não considerava RNAms modificados por splicing alternativo poderima dar origem a proteínas não funcionais. Algumas características de seqüências não funcionais estão sendo descobertas, como a excisão parcial de um intron ou um exon por um erro da maquinaria ou evento de splicing alternativo, sendo que a quantidade de nucleotídeos da sequiência excisada não é múltiplo de três [Magen (2005)]. Se isso ocorre, a fase de leitura a partir daquele ponto será modificada, produzindo novos códons que, consequentemente, traduzirão uma nova seqüência de aminoácidos na proteína. Isso poderá gerar um códon de parada em outro lugar da proteína a partir da região onde houve a excisão e se esse códon for seguido por um intron maior que 50 nucleotídeos, ele será marcado como um códon de parada prematuro (premature stop codon ou PTC) e pode ser submetido a via de degradação de RNAms (nonsense mediated mrna decay ou NMD)) [Hentze (1999)]. Entre 25-35\% dos exons alternativos introduzem mudanças de fase ou códons de parada no RNAm [Stamm (2000), Lewis (2003)]. Apesar da via de degradação de RNAm ser frequentemente utilizada para a modulação da expressão de variantes de splicing alternativo, algumas exceções vêm sendo encontradas, nas quais seqüências nucleotídicas que possuem códon de parada prematuro são traduzidas [Zhang (1997), Stockklausner (2006)].

Outro estudo, comparando cDNAs e ESTs de humanos e camundongos demonstra que sequências conservadas de RNAm com splicing alternativo do tipo retirada de exon possuem características específicas, como tamanho médio de sequências de aminoácidos e elementos repetitivos que permitem classificá-las como funcionais ou não [Sorek (2004)].

Aproximadamente $75 \%$ dos eventos de splicing alternativo ocorrem nas regiões traduzidas dos RNAms e irão afetar as regiões de codificação das proteínas [Okasaki 
(2002)]. Modificações na estrutura primária podem alterar as propriedades de ligação das proteínas, influenciando sua localização intracelular, modificando sua atividade enzimática ou a estabilidade protéica por mecanismos diversos. Um mecanismo comum é a introdução de domínios protéicos que são sujeitos a modificação pós transcricional, como fosforilação [Hiller (2005), Milanesi 2005)]. A escala em que essas modificações irão afetar as proteínas vai de súbitas mudanças de função até a perda da mesma. Algumas das proteínas modificadas por splicing alternativo diferem nas propriedades de interação com ligantes (incuindo hormônios e ácidos nucléicos), podendo haver desde a perda completa da ligação até um aumento de 2 a 10 vezes na afinidade [revisado por Stetefeld (2005)].

Atualmente, um dos grandes desafios no estudo de isoformas de splicing alternativo é verificar características estruturais comuns a esses variantes, sendo este o tópico principal dessa tese.

\subsection{Proteínas}

\subsubsection{Estrutura de proteínas}

Na mesma época em que a estrutura do DNA foi descoberta, Pauling e Corey [Pauling (1951)] publicavam as coordenadas atômicas e os fatores estruturais de cadeias polipeptídicas. A cadeia polipeptídica é formada no ribossomo, utilizando um códon (três nucleotídeos ordenados) do RNAm como molde para cada amino ácido. Os aminoácidos traduzidos irão se ligar linearmente através de ligações peptídicas. Essa cadeia linear 
(estrutura primária) forma estruturas periódicas (alfa-hélice e beta-folha), também conhecidas como secundárias, através da interação das pontes de hidrogênio entre amino ácidos da mesma cadeia. Através de interações entre os amino ácidos, as estruturas secundárias se enovelam em estruturas tridimensionais (estruturas terciárias) que, quando possuem mais que uma cadeia, podem interagir entre si formando estruturas quaternárias.

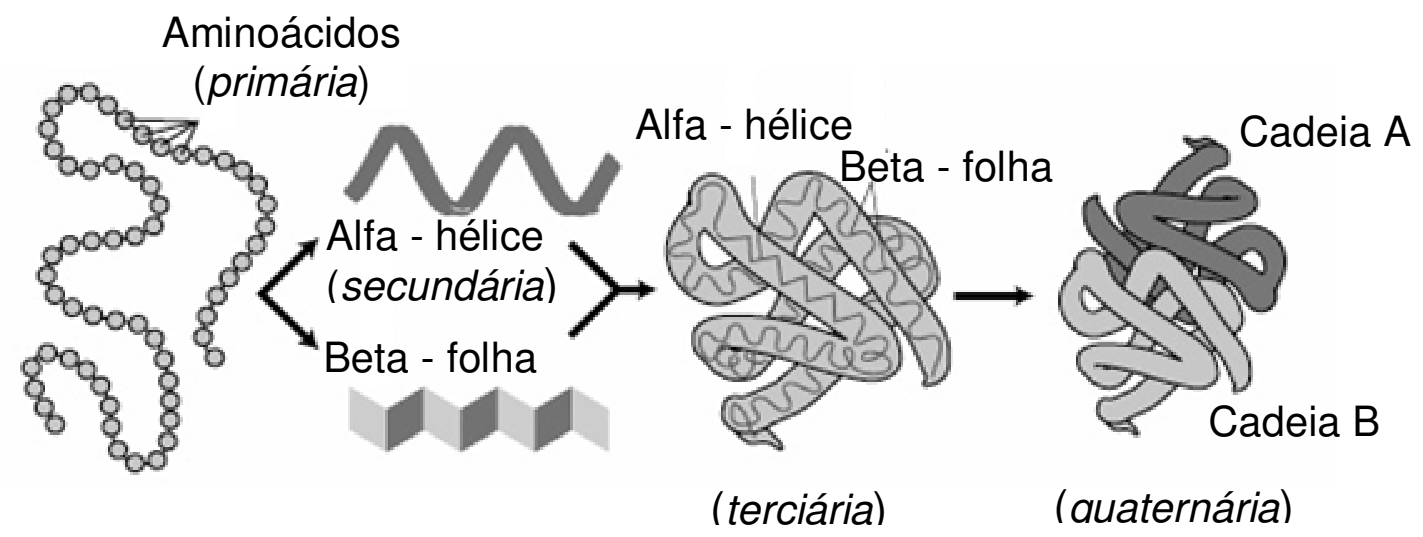

Figura 1.3.1-1 - Esquema dos tipos de estrutura protéica (adaptado de http://www.contexo.info/DNA_Basics/images/proteinstructuresweb.gif).

\section{Estruturas secundárias - Alfa-hélice}

Estruturas secundárias do tipo alfa-hélice possuem uma conformação voltada para a direita, em que o grupo N-H da cadeia principal forma uma ponte de hidrogênio com o grupo $\mathrm{C}=\mathrm{O}$ do resíduo que está 4 amino ácidos a frente. Cada amino ácido corresponde a uma volta de $100^{\circ}$ na hélice (a hélice possui 3.6 resíduos por volta). Hélices em proteínas podem conter de 4 a 40 resíduos, mas uma hélice típica contém cerca de 10 amino ácidos (cerca de 3 voltas de hélice). Pequenos polipeptídeos geralmente não exibem muitas alfahélices em solução, uma vez que o custo entrópico associado com o enovelamento da 
cadeia polipeptídica não é compensado por um número suficiente de interações estáveis. A cadeia principal de pontes de hidrogênio das alfas-hélices é considerada ligeiramente mais fraca do que a das folhas-beta e são rapidamente atacadas por moléculas de água do ambiente. Elas possuem significado particular em motivos de ligação de DNA, motivos hélice-volta-hélice, motivos ziper de leucina e motivos de dedos de zinco, estruturas comumente associadas a interação com o DNA.

\section{Estruturas secundárias - Folha-beta}

As folhas-beta são outras formas de estruturas secundárias regulares em proteínas. A maioria dessas estruturas está arranjada adjacente a outras fitas e formam uma extensa rede de interação de pontes de hidrogênio com seus vizinhos em que os grupos N-H da cadeia principal estabelecem pontes de hidrogênio com $\mathrm{C}=\mathrm{O}$ da cadeia principal de fitas adjacentes. Elas estão conectadas entre si lateralmente por 3 ou mais pontes de hidrogênio. Um motivo estrutural muito simples envolvendo duas folhas beta anti-paralelas é o grampo beta (beta hairpin). Outros mais complexos são a chave grega (greek key), que consiste em quatro fitas antiparalelas e suas respectivas voltas e o beta-alfa-beta-alfa, o motivo que forma o componente básico mais comum das estruturas das proteínas terciárias, o TIM barrel, encontrado principalmente em enzimas envolvidas em metabolismo energético [Nagano (2002)].

Outra estrutura comum em proteínas são as voltas (também conhecidas como turn, loop e, algumas vezes coil). Elas são definidas pela distância entre dois carbonos da cadeia principal $(<7$ A), quando os respectivos resíduos não estão envolvidos em um elemento 
regular de estrutura secundária como alfa-hélice e beta-folha. O papel das voltas no enovelamento das proteínas ainda é controverso. Por um lado, elas tem um papel fundamental pois unem interações entre outros elementos de estrutura secundária (hipótese suportada por estudos de mutagênese). Por outro, eles podem ter um papel passivo no enovelamento, suportado pela baixa conservação dos amino ácidos nessa região [Schmid (1993)].

A informação sobre estruturas secundárias e voltas pode ser adquirida diretamente das estruturas resolvidas experimentalmente (DSSP [Kabsch (1983)], STRIDE [Frischman (1995)]) ou pode ser predita a partir da sequência primária das proteínas. Existem muitos programas que fazem essa predição (PSIPRED [Jones (1999)], JPRED [Cuff (1998)], PHD [Rost (1993)], nnPREDICT [http://alexander.compbio.ucsf.edu/ nomi/nnpredict.html]) e cada um utiliza sua própria metodologia que vai desde realizar uma estatítica para verificar a ocorrência de estruturas secundárias em cada amino ácido da sequência.

\section{Classificação estrutural de proteínas}

Proteínas podem ser agrupadas de acordo com suas similaridades sequenciais e/ou estruturais. Para a classificação sequencial, são utilizadas as técnicas de alinhamento entre sequências a fim de encontrar padrões de aminoácidos conservados. Na classificação estrutural, os tamanhos e arranjos das estruturas secundárias de novas proteínas são comparados com estruturas tridimensionais conhecidas. A seguir, tem-se um resumo da nomenclatura utilizada na classificação de proteínas, de acordo com suas similaridades sequenciais ou estruturais: 


\section{Motivos Sequência Padrões de amino ácidos conservados que são encontrados em duas ou mais proteínas ou em um grupo de proteínas que possuem atividade bioquímica similar. Frequentemente se encontram próximo ao sítio ativo da proteína (PROSITE [Hulo (2006)]) \\ Estrutura Também conhecidos como estruturas super secundárias, os motivos estruturais são uma combinação de elementos de estrutura secundária na estrutura tridimensional

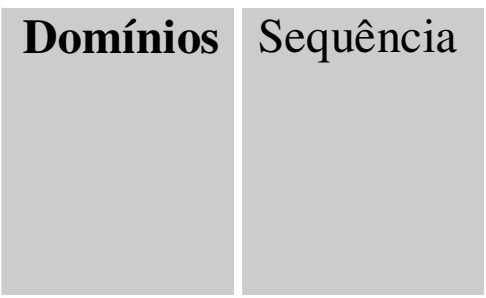 \\ Estrutura Segmento da cadeia polipeptídica que pode se enovelar independentemente em uma estrutura tridimensional sem considerar outros segmentos da cadeia. Os domínios separados de uma proteína podem interagir entre eles ou podem simplesmente estar unidos pela cadeia. Podem ser usados para interações funcionais com diferentes moléculas (DDBASE [Sowdhamini (1996)],CATH [Orengo (1997)], SCOP [Murzin (1995)]) \\ Família Sequência Grupo de proteínas com funções bioquímicas similares e que possuem similaridade sequencial maior que $50 \%$. \\ Estrutura Estruturas contendo um nível significativo de similaridade estrutural, não necessariamente seqüiencial}

Tabela 1.3.1.-3 Nomenclatura utilizada para classificação de proteínas sequencial e estruturalmente (adaptado de Mount (2004)).

Como os domínios estruturais serão estudados nesse trabalho, aqui temos um detalhamento maior desse conjunto de proteínas. Os domínios estruturais podem ser subdivididos hierarquicamente em classes, arquiteturas e enovelamentos (folds). As classes, termo usado para classificar proteínas de acordo com seu conteúdo de estruturas secundárias e sua organização, podem ser subdivididas em quatro grupos principais:

* $\alpha$ - descreve uma série de $\alpha$-hélices conectadas por voltas na superfície das proteínas;

$* \beta$ - descreve folhas $\beta$ anti-paralelas, comumente duas folhas formando um sanduíche;

* $\alpha / \beta$ - contém principalmente folhas- $\beta$ paralelas com intervenção de algumas $\alpha$ - hélices; 
$* \alpha+\beta-$ contém algumas $\alpha-$ hélices e folhas- $\beta$ anti-paralelas.

Alguns programas computacionais, como o CATH [Orengo (1997)], unem as classes $\alpha / \beta$ e $\alpha+\beta$ em uma só classe, chamadas $\alpha ; \beta$. Cada uma das classes descritas acima pode ser subdivida em muitas arquiteturas. Elas irão descrever a orientação relativa das estruturas secundárias na estrutura tridimensional, sem considerar as regiões de volta. Cada arquitetura também pode ser subdividida em um fold que irá considerar também as regiões de volta.

Estima-se que existam cerca de 1.000 famílias de proteínas com similaridade sequencial detectável [Dayhoff (1978), Chothia (1992), Yan (2005)]. Porém ainda não foi esclarecido se essa quantidade, restrita quando comparada a quantidade de proteínas existentes, ocorre por restrições físicas do enovelamento de uma cadeia polipeptídica em uma estrutura tridimensional ou simplesmente pela seleção natural de certas classes de estruturas tridimensionais pela evolução [Gibrat (1996)].

A diversidade protéica é fundamental para os organismos, sendo que estes utilizam mecanismos para controlar a quantidade em que essas proteínas são produzidas, além do local e do momento em que cada um delas será expressa. Uma estrutura tridimensional está relacionada à função que a proteína exerce no organismo. A modificação da sequência nucleotídica pode modificar a estrutura protéica e, consequentemente, a função da mesma no organismo. Alterações funcionais em proteínas cujas estruturas tridimensionais ainda não foram determinadas podem ser observadas in silico utilizando ferramentas computacionais para verificar, por exemplo, a modificação de seqüências correspondentes a motivos/domínios [Loraine (2003), Kriventseva (2003)] 


\section{Enovelamento}

Apesar de se conhecer que as estruturas protéicas são especificadas pelas seqüências de amino ácidos, essa relação não é totalmente compreendida [Braden e Tooze (1991), Voet (2000)]. O enovelamento protéico pode ser visto como uma conexão entre o genoma e a função protéica, através de sua estrutura. Porém, apesar do enovelamento de uma proteína ser determinado por sua sequência primária, a forma como ele ocorre não está completamente compreendida. Em condições fisiológicas, toda a informação necessária para ordenar a estrutura tridimensional de uma proteína está em sua sequência linear, dado que a renaturação de uma proteína nesse ambiente é um processo espontâneo. Entretanto, características do citosol, incluindo a natureza do solvente (água ou lipídios), a concentração de sais, a temperatura e a presença de chaperonas podem influenciar nesse processo. Atualmente, discute-se quem seria o principal responsável pelo enovelamento, se as interações entre as cadeias laterais ou as pontes de hidrogênio peptídicas formadas pela cadeia principal [Rose (2006)]. De qualquer forma, em ambas devem ser satisfeitas as restrições termodinâmicas descritas por Anfinsen [Anfinsen (1973)], que permitem que

uma população de proteínas possa desnaturar e/ou renaturar reversivelmente. O enovelamento incorreto das proteínas também está associado a doenças, como o Alzheimer, Creutzfeld-Jacob e fibrose cística [revisado por Selkoe (2003)].

\section{Obtenção de estruturas protéicas e estudos em larga-escala}

As estruturas protéicas podem ser descobertas por métodos experimentais, como a Cristalografia de raios-X e Ressonância Magnética Nuclear (Nuclear Magnetic Ressonance - NMR). Outros métodos menos utilizados são a Difração de Elétrons, Microscopia 
Eletrônica, e Difração de Nêutrons. As estruturas obtidas podem ser visualizadas através de ferramentas computacionais específicas como Rasmol [Sayle (1995)], Swisspdbviewer [Guex (1997)] e Pymol (http://www.pymol.org).

Para utilizar a informação das sequências de proteínas em larga escala é necessário acessar os bancos de dados com as informações experimentais/teóricas dessas sequências. O banco de dados Swiss-Prot é um banco de dados de sequência de proteínas anotadas, em que também estão disponibilizadas algumas informações adicionais, como características bioquímicas e isoformas de splicing alternativo. Todas as sequências são inicialmente depositadas no TrEMBL [Bairoch (2000)], um banco de dados de sequências nucleotídicas traduzidas do banco de dados de sequências nucleotídicas do EMBL. A partir desse ponto, a sequência é analisada para verificar se ela alinha (BLAST ou FastA) contra alguma das sequências do próprio Swiss-Prot/TrEMBL [Bairoch (2000)]. As informações dessas sequências passam por processos diferentes de anotação dependendo se há ou não informação bioquímica sobre aquela sequência, ou seja, se a proteína foi isolada e caracterizada in vivo, permitindo uma associação da sequência com determinada família de proteínas.

O único banco de dados de estruturas protéicas resolvidas experimentalmente é o Protein Data Bank (PDB) [Bernenstein (1977), Berman (2002)]. Esse banco possui cerca de 30.000 estruturas depositadas de diferentes organismos, podendo estar associadas a fármacos e peptídeos ou em seu estado livre. As sequiências das proteínas depositadas nesse banco e todos os outros dados estruturais podem ser utilizados na comparação com outras sequências e estruturas ou na construção de modelos teóricos. Porém, como esse banco possui dados experimentais gerados por diferentes grupos ao redor do mundo, ele apresenta discordância em algumas informações e redundância para proteínas com funções muito 
estudadas, como enzimas. Além disso, muitas estruturas são apenas pedaços de proteínas devido a restrições experimentais, o que dificulta o estudo em bioinformática. Um exemplo dessa dificuldade pode ser visto através dos resultados de um estudo recente sobre a cobertura funcional do genoma humano considerando a informação estrutural existente [Xie (2005)]. Nele, mostrou-se que o PDB necessita de mais informação para proteínas

associadas a doenças, domínios transmembranares, regiões de baixa complexidade e regiões desordenadas. No caso de isoformas de proteínas modificadas por splicing alternativo, não chegam a quinze a quantidade atual de estruturas disponibilizadas no PDB [Stetefeld (2005)], como veremos detalhadamente a seguir.

\subsubsection{Splicing Alternativo e Estruturas de proteínas}

Uma forma de iniciarmos a análise das modificações estruturais e funcionais nas isoformas de splicing alternativo é utilizando os dados experimentais disponíveis sobre essas proteínas. A tabela a seguir apresenta um resumo das características das proteínas modificadas pelo evento de splicing alternativo com estrutura protéica determinadas experimentalmente e disponíveis no banco de dados PDB. 


\begin{tabular}{|c|c|c|c|c|}
\hline $\begin{array}{c}\text { Isoformas } \\
\text { A (pdb) / B (pdb) }\end{array}$ & Função & $\begin{array}{c}\text { Tamanho } \\
\text { (aas) }\end{array}$ & Modificação estrutural & Modificação funcional \\
\hline $\begin{array}{c}\text { EDA-A1 (1rj7) / } \\
\text { EDA-A2 (1rj8) }\{1\}\end{array}$ & $\begin{array}{l}\text { Fator de necrose } \\
\text { tumoral }\end{array}$ & 2 aas & $\begin{array}{c}\text { Mudança na conformação e na } \\
\text { distribuição de carga no sítio ativo }\end{array}$ & $\begin{array}{c}\text { Especificidade do receptor de EDAR e } \\
\text { XEDAR }\end{array}$ \\
\hline $\begin{array}{c}\text { AdGST1-3 (1jlv) / } \\
\text { AdGST1-4 (1jlw) \{2\} }\end{array}$ & $\begin{array}{l}\text { Glutationa S- } \\
\text { transferase }\end{array}$ & 5 aas & $\begin{array}{c}\text { Mudança no canal de ligação do } \\
\text { substrato }\end{array}$ & Altera especificidade do substrato \\
\hline $\begin{array}{c}\text { AGX1 (1jv1) / } \\
\text { AGX2 (1jvd) }\{3\}\end{array}$ & $\begin{array}{c}\text { Fosforilase } \\
\text { Humana }\end{array}$ & 17 aas & $\begin{array}{l}\text { Inibe formação de dímero e } \\
\text { modifica sítio ativo }\end{array}$ & $\begin{array}{l}\text { Controle da oligomerização } \\
\text { Regulação da especificidade } \\
\text { Expressão tecido-específica }\end{array}$ \\
\hline $\begin{array}{c}\text { Rac1a (1ryf) / } \\
\text { Rac1b(1ryh) }\{4\}\end{array}$ & GTPase & 19 aas & $\begin{array}{l}\text { Modifica conformação de duas } \\
\text { regiões (switch I / II) }\end{array}$ & Inibe hidrólise de GTP \\
\hline $\begin{array}{l}\text { SULT2B1a }(1 \mathrm{q} 1 \mathrm{q}) / \\
\text { SULT2B1b } \\
(1 \mathrm{q} 1 \mathrm{z})\{5\}\end{array}$ & $\begin{array}{l}\text { Sulfo -transferase } \\
\text { humana }\end{array}$ & $\begin{array}{l}8 \text { aas / } \\
23 \text { aas }\end{array}$ & $\begin{array}{l}\text { Diferença na ligação catalítica } \\
\text { Modificação da orientação de } \\
\text { hélice do N-terminal }\end{array}$ & $\begin{array}{c}\text { SULT2B1a prefere ligar } \\
\text { pregnenolona } \\
\text { SULT2B1b prefere ligar colesterol }\end{array}$ \\
\hline $\begin{array}{c}\text { G3-B0 (1q56) / } \\
\text { G3-B8 (1pz7) / } \\
\text { G3-B11 (1pz8) \{6\} }\end{array}$ & $\begin{array}{l}\text { Domínio } \\
\text { Agrinina }\end{array}$ & $\begin{array}{l}8 \text { aas / } \\
11 \text { aas / } \\
19 \text { aas }\end{array}$ & $\begin{array}{l}\text { Rearranjo do loop L2-3 } \\
\text { Adição de "rim sheet" } \\
\text { Reorientação de beta }\end{array}$ & $\begin{array}{c}\text { Regulação da ligação } \\
\text { Controle de AchR } \\
\text { Expressão tecido-específica }\end{array}$ \\
\hline $\mathrm{C} 2 \mathrm{~A}(1 \mathrm{rh} 8)\{7\}$ & $\begin{array}{l}\text { Domínio } \\
\text { Piccolo }\end{array}$ & 9 aas & $\begin{array}{c}\text { Formação de } 2 \text { alfa-hélices e } \\
\text { reorientação do local de interação } \\
\text { do } \mathrm{Ca}^{2+}\end{array}$ & $\begin{array}{l}\text { Alteração da ligação de } \mathrm{Ca}^{2+} \\
\text { Dimerização dependente de } \mathrm{Ca}^{2+}\end{array}$ \\
\hline
\end{tabular}


Tabela 1.3.1.1-1 - Resumo das características das estruturas experimentais de proteínas modificadas por splicing alternativo (adaptado de Stetefeld (2005) e Romero (2006)). As referências para cada estrutura são: $\{1\}$ [Hymowitz (2003)]; $\{2\}$ [Oakley (2001)]; $\{3\}$ [Peneff (2001)]; $\{4\}$ [Fiegen (2004)]; $\{5\}$ [Lee (2003)]; $\{6\}$ [Stetefeld (2004)] e $\{7\}$ [Garcia (2004)].

Podemos verificar que todas as modificações levam a uma alteração na especificidade com o inibidor e/ou a capacidade de dimerização. Entretanto, devido a pequena quantidade de estruturas disponíveis não é possível realizar uma análise estatística confiável das características estruturais/funcionais comuns à essas proteínas. Podemos notar modificações sutis nessas estruturas variantes, que poderiam não ocorrer em outras proteínas no genoma humano (cerca de 100.000). Além disso, todas as estruturas disponíveis possuem deleções/inserções menores que 25 aminoácidos, também prejudicando o estudo do efeito do splicing alternativo com inserções/deleções maiores que esse tamanho.

Enquanto não são disponibilizadas mais estruturas experimentais de variantes de splicing alternativo, estudos in silico sobre as estruturas modificadas pelo evento de splicing vêm sendo realizados recentemente a fim de se obter maior conhecimento sobre as modificações causadas por esse evento. Um dos primeiros estudos teóricos em larga-escala selecionou 40 seqüências que foram alteradas por splicing alternativo e realizou a Modelagem Molecular por Homologia (MMH) dessas sequências utilizando 14 proteínas do PDB como molde [Furnham (2004)]. Nesse estudo foi visto que, na maioria das vezes, a região em que ocorre o splicing alternativo está associada a perda ou ganho de grandes unidades estruturais e/ou a regiões de modificações pós-traducionais, com a modificação de 
peptídeos sinais no N-terminal ou sítios de glicosilação. Algumas dificuldades técnicas foram observadas durante a MMH de proteínas modificadas por splicing alternativo, principalmente na dificuldade da modelagem de inserções comparado a modelagem de deleções. Entretanto, esse resultado é esperado, uma vez que os programas de MMH têm a premissa que duas proteínas com sequências similares possuem estruturas semelhantes. Entretanto, estruturas com inserções/deleções não estão descritas na parametrização desses programas e inserções acarretam mais modificações estruturais do que deleções, uma vez que são incluídas novas interações entre resíduos espacialmente próximos ou distantes.

Um outro estudo relevante sobre estruturas de proteínas com splicing alternativo demonstrou que uma inserção de 9 aminoácidos em um dos domínios da proteína Picollo levou a uma modificação estrutural inesperada [Garcia (2004)]. Foi feita a modelagem dessa inserção, que ocorria em uma região de volta e no modelo construído essa região foi estendida. Porém, o experimento de ressonância magnética nuclear (NMR) dessa mesma proteína demonstrou que essa região não era estendida e, ao invés disso, havia um rearranjo espacial dos aminoácidos que fazia com que a estrutura em torno da volta onde havia a inserção fosse conservada e a modificação estrutural ocorresse na alfa-hélice a qual a volta estava ligada, que foi estendida. Essa nova informação sobre modificações estruturais causadas por splicing alternativo trouxe mais dúvidas quanto às técnicas utilizadas para predizer estruturas com essas modificações, além de questionar se esse tipo de comportamento estrutural seria uma exceção, uma vez que esse comportamento não foi verificado nas outras estruturas variantes que possuem estrutura determinada experimentalmente.

Alguns estudos mais recentes mostraram características das estruturas das proteínas variantes de splicing alternativo em larga escala [Wang (2005), Romero (2006), Yura 
(2006), Tress (2007)]. Em um deles [Wang (2005)] foi demonstrado que o tamanho dos eventos de splicing segue a distribuição da "lei de força", em que quanto maior a região deletada/inserida, mais raro é o evento. Neste mesmo trabalho, foi feito um estudo estrutural somente das bordas dos sítios de splicing alternativo (considerando-as como inserção, deleção e subsituição) e verificou-se que essas bordas geralmente ocorrem em regiões de estrutura secundária de volta (“coil”), em resíduos expostos ao solvente e na superfície das proteínas. Esse mesmo estudo sugere uma outra técnica de modelagem para a construção de modelos baseados em seqüências modificadas por splicing alternativo, o threading, em que uma seqüência alvo é utilizada contra uma biblioteca de enovelamentos buscando aquelas estruturas com os melhores alinhamentos sequência-estrutura. No caso das isoformas de splicing alternativo, $50 \%$ das proteínas reconstruídas possuíam uma estrutura razoável, contendo poucas alterações nas regiões de estrutura secundárias do centro (core) da proteína.

Características estruturais e funcionais de regiões inseridas/deletadas por splicing alternativo foram relacionadas a regiões protéicas "intrinsicamente desordenadas" por Romero e colaboradores [Romero (2006)]. As regiões desordenadas em proteínas estão associadas a alta mobilidade e a determinadas funções, como regulação e sinalização celular. Essas regiões também foram relacionadas ao splicing alternativo através da análise de regiões deletadas ou inseridas nas proteínas de organismos multicelulares, permitindo a modulação da função protéica necessária para a diversidade celular.

Outras características estruturais e funcionais das regiões de splicing alternativo em proteínas foram vistas por Yura e colaboradores [Yura (2006)] das quais podemos destacar, entre outras modificações, que $67 \%$ das isoformas demonstraram alterações significativas 
nas regiões centrais (core) das proteínas, o que poderia resultar em grandes modificações estruturais.

O mais recente desses trabalhos [Tress (2007)] faz uma análise que inclui outras características protéicas como peptídeos sinais e domínios transmembranares e sugere que os variantes de splicing poderão sofrer modificações funcionais significativas, mas essas modificações seriam exceções de difícil detecção nas estruturas protéicas.

Resumindo, os efeitos do splicing alternativo sobre as estruturas protéicas ainda não estão completamente desvendados, não sendo possível concluir se as isoformas de splicing alternativo possuirão modificações estruturais significativas. Mais detalhes sobre os métodos e resultados dos trabalhos de larga-escala relacionando splicing alternativo e estruturas de proteínas serão discutidos durante a apresentação dos resultados e discussões dessa tese, a seguir. 


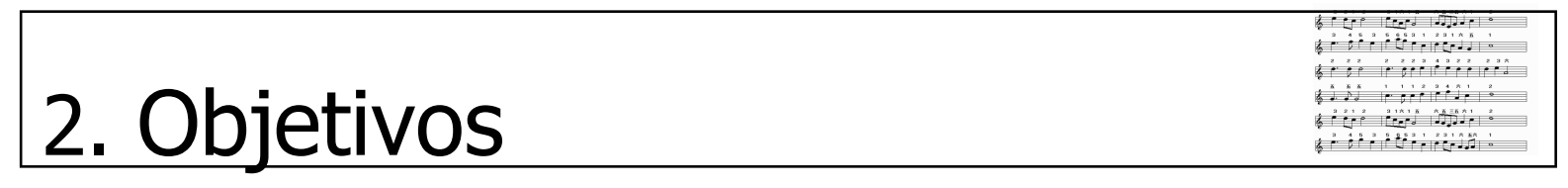




\subsection{Objetivo Geral}

Esse trabalho tem como objetivo principal compreender os efeitos do mecanismo de splicing alternativo sobre as estruturas protéicas. Nele foi realizada uma análise em largaescala das estruturas das isoformas de splicing alternativo humanas utilizando ferramentas de bioinformática.

\subsection{Objetivo Específico}

Descrever quais são os principais fatores estruturais que realizam modificações nas estruturas das isoformas de splicing alternativo através da comparação das características estruturais das bordas e das regiões de splicing alternativo com características de outros aminoácidos/regiões da proteína na qual ocorre o evento. 


3. Métodos


Os métodos utilizados nesse trabalho se concentram no uso de programas para a manipulação e análise das sequências nucleotídicas e protéicas. Alguns desses programas foram previamente construídos por outros grupos e já se encontravam publicamente disponíveis enquanto outros, específicos para esse trabalho, foram desenvolvidos localmente utilizando a linguagem Perl. Foi feito um pipeline para mapear as regiões de splicing alternativo detectadas em sequências nucleotídicas relacionadas aos principais eventos de splicing alternativo (retenção de intron, retirada de exon e uso alternativo dos sítios de splice) nas proteínas que possuem estrutura tridimensional. Após a detecção das regiões de splicing alternativo nas estruturas das proteínas, foram feitas análises sobre as características estruturais dessas regiões.

\subsection{Detecção de casos de splicing alternativo}

O protocolo a seguir vêm sendo utilizado em nosso laboratório para a obtenção das bordas de splicing das sequências de cDNA e sua localização no genoma. [Galante (2004), Kirschbaum-Slager (2005)].

No site da Universidade da Carolina do Sul (http://hgdownload.cse.ucsc.edu) estão disponíveis as sequências do genoma humano (NCBI build \# 35), sequências de cDNAs (186.358) e ESTs (5.992.459) utilizadas nesse trabalho. As sequências de cDNA foram alinhadas com o genoma humano pelo UCSC utilizando o programa BLAT (Blast-like Alignment Tool) [Kent (2002)] permitindo a obtenção de dados como contigs, cromossomos e localização das bordas de splicing. 
Como o BLAT apresenta limitações no alinhamento das bordas das sequências, que é exatamente o local onde é necessária uma maior precisão para a identificação dos transcritos que possuem splicing alternativo, utilizamos o programa SIM4 [Florea (1998)] para realinhar as seqüências com os melhores resultados (hits) no genoma, utilizando a informações adicionais do BLAT para agilizar esse processo. Somente foram aceitos os melhores alinhamentos de transcritos com identidade maior que $94 \%$ e cobertura maior que 50\%. Após esse ajuste das barreiras exon-intron, as sequiências foram depositadas em um banco de dados local com as seguintes informações: bordas exon-intron e no RNAm, região codificante (coding region (CDS)) das seqüências de RNAm, identidade do alinhamento dada pelo SIM4, fita (+ / -) em que a sequência é traduzida, grupo (cluster) em que essa seqüência se encontra e outras seqüências do mesmo grupo (cluster).

Utilizando as sequências de RNAm como referência foi possível realizar uma busca par a par dos RNAms e ESTs que representam os mesmos genes e possuem pelo menos uma barreira exon-intron diferente para o mesmo exon, caracterizando os casos de splicing alternativo do tipo uso alternativo $5^{\prime} / 3^{\prime}$, retenção de intron ou retirada de exon.

Considerando somente as sequências de RNAm foram encontrados 136.231 casos representando splicing do tipo uso alternativo, 138.400 casos de retenção de intron e 74.360 casos de retirada de exon. Considerando também as sequências de ESTs, encontramos 1.414.274 casos do tipo 5'ss e 3'ss, 1.087 .433 casos de retenção de intron e 1.016.932 casos de retirada de exon. Esses números certamente são redundantes pois a comparação foi realizada entre todos os exons de todas as sequências conhecidas, havendo muitas sequências que reportam o mesmo evento de splicing. Podemos retirar a redundância desses casos pela quantidade de grupos (clusters) do Unigene, sendo possível verificar que existem 10.695 clusters de genes que possuem bordas discordantes nas sequências de RNAms e 
14.196 clusters reportando aos casos discordantes adicionando as sequências de EST. Considerando que o número de clusters do Unigene para sequências humanas representado por pelo menos um RNAm é 25.451, observamos que a proporção de genes que sofrem splicing alternativo nos nossos dados está entre $42 \%$ e $55 \%$ (somente entre RNAms e incluindo ESTs, respectivamente). Essas proporções se encaixam perfeitamente na estimativa de que entre 45 - 60\% dos genes podem estar sendo modificados por splicing alternativo [Modrek (2002), Johnson (2003)].

Inicialmente, todas as sequências que reportam prováveis casos de splicing alternativo foram consideradas nesse trabalho, sendo descartadas à medida em que não se encaixavam nos parâmetros do pipeline para a detecção de estruturas protéicas com splicing alternativo.

Possuindo todas as bordas conflitantes dos exons das sequências nucleotídicas é possível contabilizar a quantidade de sequências (mRNAs ou ESTs) relacionadas a cada borda genômica. Com esse dado, normalizado, poderíamos comparar a frequência de sequências relacionadas a cada borda e assinalar se as mesmas são constitutivas ou alternativas. A definição de constitutivo/alternativo para bordas genômicas ou genes considera que o variante com maior expressão (maior frequência) seria constitutivo, enquanto aqueles menos expressos (menor frequência) seriam alternativos [Gupta (2004)]. Porém essa definição é conflitante quando não temos todas as bordas ou genes associados a casos "normais", ou seja, quando o tecido sequenciado também está relacionado a doenças. No nosso dado, cerca de metade dos casos de AS com ESTs estão relacionados a tecidos tumorais. Com isso, a denominação contitutivo/alternativo não estaria sendo corretamente aplicada, pois aquelas sequências mais expressas em tumor seriam consideradas constitutivas e as menos expressas consideradas como alternativas. Outro trabalho realizado 
pelo nosso grupo não conseguiu associar variantes de splicing alternativo tumor-específico, ou seja, verificou que os variantes de splicing encontrados em determinados tecidos tumorais são também encontrados em tecidos normais, sendo que a diferença entre eles é a quantidade de expressão do variante [Kirschbaum-Slager (2005)]. Portanto, nesse trabalho consideraremos todos os casos de splicing alternativo mapeados a proteínas como isoformas ou variantes que poderão ser expressos em maior ou menor quantidade, estando ou não associados a doenças, mas que modificarão a estrutura da proteína resultante.

\section{Protein Data Bank (PDB)}

Nesse trabalho foram utilizadas as informações do PDB, o banco de dados de estruturas protéicas. Inicialmente, foram encontradas 20,340 sequências de cadeias de proteínas humanas. Foram excluídas as sequiências de DNA, RNA e heteroátomos e foi retirada a redundância entre as cadeias (somente sequências idênticas), restando 3.961 cadeias não-redundantes de proteínas humanas. O problema da redundância entre sequências muito similares será tratado mais adiante nesse capítulo.

\section{Alinhamento proteína $x$ splicing alternativo}

O alinhamento local par-a-par realizado pelo BLAST [Altschull (1990)] permite identificar as diferenças entre duas seqüências, sendo possível mapear os prováveis sítios de splicing entre a seqüências de mRNA e a seqüência protéica. Nesse trabalho foi utilizado o TBLASTN (BLAST entre um banco de sequências nucleotídicas traduzidas e protéicas) para a detecção de dissimilaridades locais entre as sequências. Os parâmetros do BLAST 
foram modificados, como sugerido por Korf e colaboradores [Korf (2003)]. Segundo os autores, os alinhamentos são como experimentos em que pequenas modificações podem colaborar na visualização do resultado desejado. No nosso caso, foi anulado o custo para abertura de um intervalo (gap) e foi atribuído um baixo custo para extensão desse intervalo (1) para os alinhamentos, uma vez que era esperado aparecem intervalos em vários locais da sequência. Além disso, não foi utilizado o filtro de baixa complexidade, que mudaria o valor das identidades nos alinhamentos, dificultando a identificação do real valor da mesma nas sequências.

Inicialmente foi utilizado um parseador de BLAST em que a saída consistia principalmente na descrição do nome da proteína (query), da sequência de mRNA ou EST alinhado com a mesma (subject), na identidade e na descrição dos intervalos (gaps) encontrados no alinhamento. Logo foi visto que a identidade não era diretamente relacionada a similaridade entre as sequências devido aos intervalos inseridos pelo evento de splicing alternativo. O cálculo da identidade entre duas sequências alinhadas do BLAST é feito usando a seguinte fórmula:

$$
\mathbf{I}_{\mathbf{b}}=\mathbf{M} / \mathbf{T}
$$

em que $\mathrm{I}_{\mathrm{b}}$ é a identidade do Blast, M (Match) é a quantidade de aminoácidos que são idênticos nas duas sequências do alinhamento e T (Total) é o tamanho total da região alinhada. Podemos exemplificar esse cálculo no alinhamento a seguir:

AFGAHAJAHAPPLKSTVA _ sequência A (ptn) AHGAHA- - - APPKLSTVA _ sequência B (nt traduzido) 
em que a identidade do alinhamento (Ib) é 9/18 = 0,5 (50\%).

Porém os intervalos (gaps ou separação dos alinhamentos) que ocorrem nas sequências não devem ser contados como parte do total de aminoácidos, uma vez que esses intervalos são esperados nos casos de splicing alternativo e não podem ser penalizados da mesma forma que, por exemplo, uma série de mutações pontuais ao longo da proteína. Portanto, foi utilizada uma nova forma de calcular a identidade para detectar casos mais significativos:

$$
\mathbf{I}_{\mathrm{mb}}=\mathbf{M} /(\mathbf{T}-\mathbf{G})
$$

em que $\mathrm{I}_{\mathrm{mb}}$ é a identidade modificada do Blast, $\mathrm{M}$ é a quantidade de aminoácidos que são idênticos nas duas sequências do alinhamento, T é o tamanho total da região alinhada e $\mathrm{G}$ (Gap) é o tamanho do intervalo encontrado no alinhamento. Podemos exemplificar esse cálculo no mesmo alinhamento anterior em que a identidade do alinhamento corigida (Imb) passa a ser $9 /(18-3)=0,6(60 \%)$. O aumento de valor na nova identidade estimada ocorreu porque foi desconsiderada a região que não se alinhou e que, anteriormente a esse recálculo, era penalizada.

Após essa correção, foram selecionadas sequências com identidade corrigida maior ou igual a 90\%. Aqueles alinhamentos que não apresentavam alinhamento com a porção $\mathrm{N}$ e/ou C terminal da proteína query foram ressubmetidas a um programa local para que esses possíveis casos de splicing não fossem perdidos. Esse programa concatena uma cauda poliK com 15 nas pontas $\mathrm{N}$ e C-terminal de uma sequência protéica e uma cauda poli-A de tamanho 45 nas bordas $5^{\prime}$ e $3^{\prime}$ na sequência nucleotídica alinhada com essa proteína. O nucleotídio adenina (A) foi escolhido para compor essa região por ser traduzido em lisina em qualquer fase de leitura. As sequências do PDB também foram submetidas ao mesmo 
pocedimento só que utilizando lisinas $(\mathrm{K})$ de tamanho 15 (menor tamanho possível considerando o tamanho de palavra utilizada pelo TBLASTN para procurar seqüências relacionadas entre si). O TBLASTN foi então refeito, permitindo a correção dos efeitos de borda do alinhamento local sobre elas, esperando-se que as regiões adicionais de lisinas (K) fossem alinhadas as regiões traduzidas de adeninas e aparecessem intervalos somente em locais de splicing alternativo que antes estavam nas bordas, mas acabaram por ser excluídos do resultado do alinhamento, devido a característica de alinhamento local do BLAST. O alinhamento anterior (a) e o novo alinhamento (b) com a concatenação da cauda estão exemplificados a seguir:

(a)

EFGHIKLMNPQRSTVWY _ sequência A (ptn)
EFGHIKLMNPQRSTVWY _ sequência B (nt traduzido)

(b)

KKKKKKKKKKACDEFGHIKLMNPQRSTVWY _ sequência A (ptn)

KKKKKKKKKKA - - EFGHIKLMNPQRSTVWY _ sequência B (nt traduzido)

Com esse re-alinhamento (b) é possível localizar o splicing alternativo no começo ou fim da proteína com um parseamento simples, eliminando o efeito de borda dado pelo alinhamento local do BLAST.

Também foram manualmente verificados os casos em que o alinhamento, por ser local, foi dividido em duas ou mais partes. Esses casos exigem especial cuidado pois 
poderia haver mudança de fase devido ao splicing alternativo. Entretanto, utilizando essas duas técnicas para evitar problemas de alinhamento do BLAST, conseguimos acrescentar somente cerca de 10 casos aos dados de AS relacionados a estrutura protéica.

\section{Relocalização das bordas genômicas de splicing alternativo a partir do} resultado do alinhamento

Observando nossos resultados foi possível verificar que podemos dividir nossos intervalos de splicing em dois tipos: deleção e inserção. Alguns autores utilizam a classificação de substituição, quando um pedaço da sequência é deletado e outro inserido no mesmo local [Wang (2005), Yura (2006)]. As inserções e deleções que ocorrem na mesma sequência são considerados por nós como eventos independentes. A soma dos resultados obtidos para os dois eventos nesse trabalho será chamada de "indel".

Como pode ser visto na figura a seguir, são considerados casos de deleção quando a sequência do PDB possui um trecho de aminoácidos ausentes na sequência nucleotídica traduzida (sequência alinhada). Nesse caso temos a informação estrutural das bordas de splicing e de toda a região que sofreu splicing alternativo. Os casos de inserção são aqueles em que o trecho de aminoácidos não está presente na sequência protéica, mas existe na sequência alinhada. Nesse caso temos somente a informação das bordas de splicing. 
A. Deleção

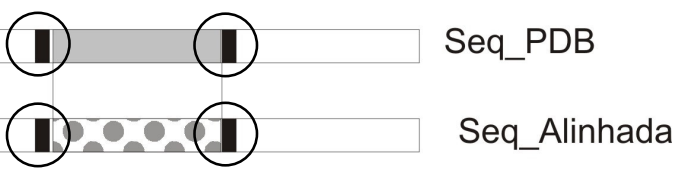

B. Inserção

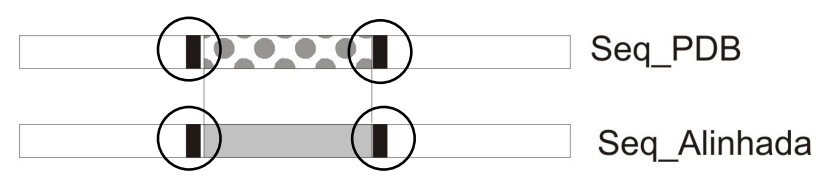

Figura 3.1.1. Demonstração esquemática dos casos de inserção e deleção detectados a partir do alinhamento entre candidatos de splicing alternativo e sequências derivadas de estruturas protéicas. As regiões em preto circundadas correspondem a região flanqueadora (aminoácidos logo antes ou depois da região de splicing alternativo). A. Região em cinza corresponde a uma deleção na sequência alinhada em relação ao PDB, o qual possui toda a informação estrutural dessa região. A região com textura corresponde a região da sequência nucleotídica cujo correspondente é o trecho em cinza do PDB, que inclui a informação da região flanqueadora. B. Região em cinza corresponde a uma inserção na sequência alinhada em relação ao PDB. A região com textura corresponde a uma região inexistente no PDB, em que somente temos a informação da região flanqueadora. 
A.

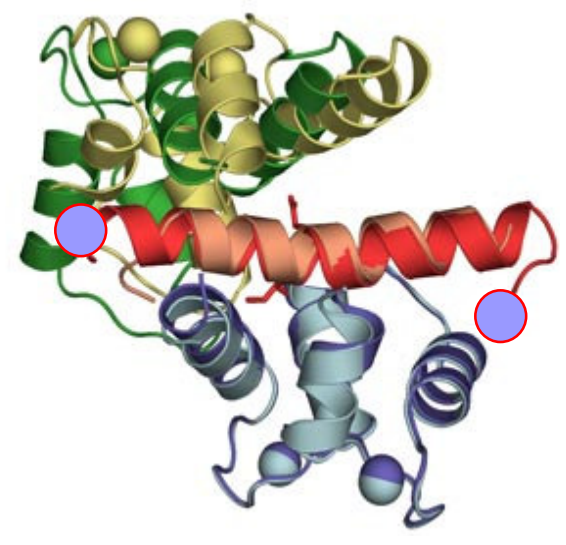

B.

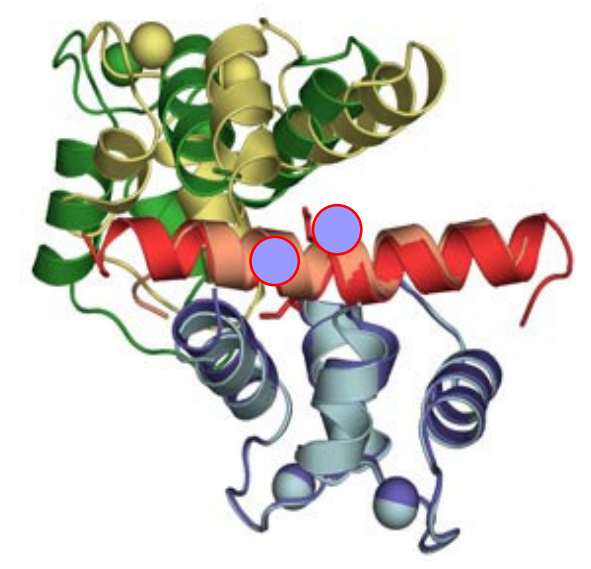

Figura 3.1.2. Demonstração esquemática na estrutura protéica dos casos de deleção (A) e inserção (B) detectados a partir do alinhamento entre candidatos de splicing alternativo e sequências derivadas de estruturas protéicas. Os círculos correspondem às regiões flanqueadoras.

Nos nossos dados, quando há somente um caso de inserção ou deleção ao longo da proteína podemos considerar como um caso simples, em que a localização do intervalo pode ser diretamente calculada a partir do alinhamento processado (parseado). Nele, podemos verificar a localização e o tamanho do intervalo na proteína.

Porém, existem casos em que mais que um evento de inserção/deleção pode ser visto ao longo da proteína. Como nossa referência para a localização do splicing é a proteína do $\mathrm{PDB}$, nos casos de inserção que ocorrem mais que vez, chamados aqui de complexos, uma vez que a localização do splicing na estrutura protéica tem que ser recalculado. 
Utilizamos todas as localizações dos intervalos nas sequências correspondentes as estruturas protéicas para confirmar que esses intervalos de inserção e deleção não são artefatos, através da comparação com a localização dos eventos de splicing nas sequiências nucleotídicas. Para isso, alguns programas foram desenvolvidos para comparar a localização das bordas exon-intron do transcrito no genoma, no mRNA e no alinhamento com a proteína, a fim de minimizar os erros causados por ESTs de baixa qualidade. Só consideramos as bordas genômicas em que mais que um transcrito (RNAm ou EST) está alinhado na mesma região da sequência protéica.

\section{Retirada da redundância do Protein Data Bank (PDB)}

O banco de dados de estruturas de proteínas "Protein Data Bank" (PDB) é o único banco de dados público que disponibiliza as coordenadas de estruturas protéicas de diversos organismos. Portanto, verificamos as características gerais das estruturas protéicas humanas contidas nesse banco antes de realizar as análises sobre aquelas estruturas associadas a eventos de AS. Sabendo que esse banco somente disponibiliza estruturas protéicas determinadas experimentalmente, certamente teremos um viés dado por restrições experimentais para a obtenção de estruturas (especialmente para as técnicas de cristalografia de raios-X, a mais utilizada para determinação de estruturas depositadas no PDB).

Dados de genômica estrutural obtidos por Bourne e Xie [Xie (2005)] mostram que há distribuições funcionais menos representadas no PDB. Cerca de 2.000 genes humanos (não-redundantes e que possuem anotação) não possuem estruturas disponíveis nesse banco e nem correspondentes com identidade suficiente para permitir a predição dessas estruturas 
utilizando, por exemplo, a técnica de Modelagem Molecular por Homologia (MMH). Desse genes, cerca de 50\% incluem domínios transmembranares, casos especialmente difíceis de serem obtidos devido ao viés experimental, em especial devido a sua alta hidrofobicidade. Estratégias de desenvolvimento e obtenção de estratégias de cristalização de proteínas de membrana [Caffrey (2003)] estão sendo estudadas e podem solucionar esse problema nos próximos anos.

O depósito de estruturas protéicas por grupos de pesquisa independentes também contribui para um aumento na quantidade de proteínas redundantes. Essa redundância pode ser notada pela quantidade de estruturas quase idênticas, que diferem em apenas algumas mutações ou nos ligantes complexados as mesmas. Estruturalmente, a presença dessas proteínas é muito importante, pois pequenas modificações nas sequências primárias podem modificar a estrutura e a função das proteínas. Entretanto, estudos de características estruturais em larga-escala são prejudicados por esse fato. Um exemplo extremo pode ser dado pela hemoglobina, proteína que transporta oxigênio através dos glóbulos vermelhos. Foram encontradas 181 estruturas de hemoglobinas humanas relacionadas a 38 ligantes diferentes no PDB. Além disso, como dito anteriormente, temos a sub-representação de isoformas protéicas para os eventos de splicing alternativo em todos os organismos.

Portanto, após verificar essas tendências a sub-representação de algumas estruturas e super-representação de outras, decidimos analisar manualmente os dados iniciais de pares de sequências de AS associadas a estruturas protéicas a fim de identificar os casos de redundância mais comuns e como poderíamos removê-los. Nessa análise foi possível verificar um viés dado, em sua maioria, pela grande quantidade de cadeias de proteínas PDB com sequências idênticas (das 11.545 cadeias protéicas humanas, 3.961 não são redundantes). Reanalisando essas 3.961 cadeias não redundantes, vimos que ainda existia 
um viés dado por estruturas quase idênticas, mutadas ou parcialmente representadas. Para corrigir esse viés, foram testadas duas maneiras e ambas mostraram-se igualmente eficientes: uma utilizado o agrupamento (cluster) de similaridade de proteínas do PDB, que agrupa proteínas de acordo com a identidade entre elas e a outra por agrupamento das sequências nucleotídicas muito semelhantes utilizando o Unigene (como descrito em métodos) que poderia ser utilizado para as sequências mapeadas a estruturas protéicas.

Como dito anteriormente, mesmo após a retirada da redundância entre sequências idênticas do PDB, temos um conjunto de proteínas que possuem sequências muito similares (mas que não são idênticas). Para tentar a quantidade dessas seqüências, o próprio PDB disponibiliza uma lista de proteínas clusterizadas (agrupadas) com indentidade maior ou igual a 95\%, 90\%, 70\% e 50\% e proteínas não-clusterizadas (não-agrupadas). Nesse trabalho, utilizamos o agrupamento das proteínas do PDB com 90\% de identidade (chamados aqui de cluster_pdb_90\%) por ser uma identidade suficientemente alta para agrupar proteínas quase indênticas. Em todas as análises, os nomes das proteínas do PDB foram substituídos pelos seus respectivos identificadores do grupo (cluster).

A seguir, verificamos a distribuição das cadeias de proteínas não-idênticas (3.961) e das proteínas agrupadas associadas a eventos de splicing alternativo (173 grupos em cluster_pdb_90\%). 


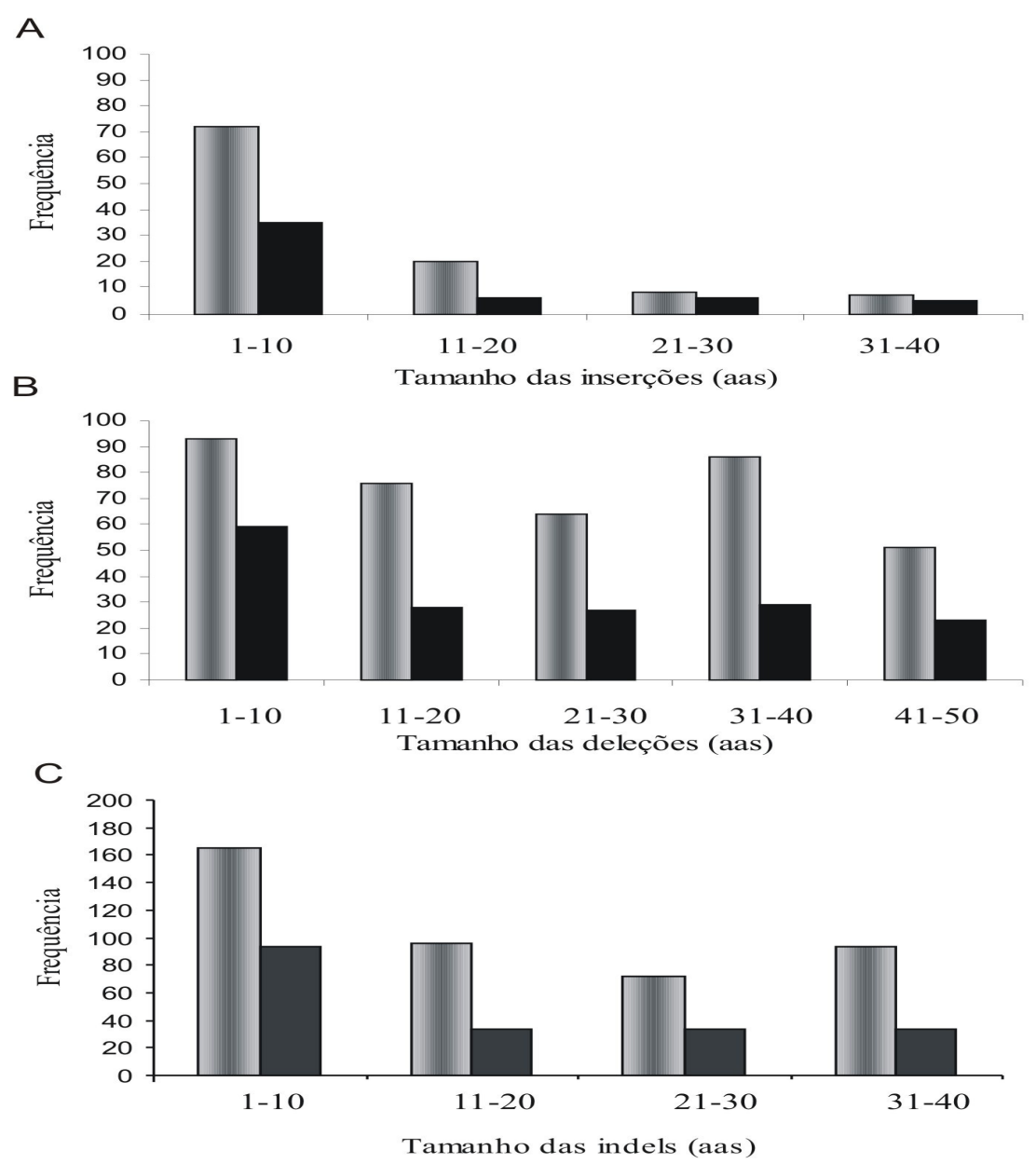

Figura 4.2.1. Frequência de eventos de AS mapeados a estruturas protéicas de acordo com o tamanho do evento para intervalos de 10 aminoácidos em: A. inserções; B. Deleções C. Indels. Barras cinzas correspondem ao dado completo e pretas correspondem ao dado sem redundância (cluster_90\% do PDB).

A redundância dos trechos de inserção e deleção devido a localização das posições das bordas de splicing alternativo em cada uma das proteínas também foi retirada, como detalhadamente descrito nos métodos.

Finalmente, nossos dados de casos de AS relacionados a estrutura de proteínas mostraram que 386 trechos (199 regiões de AS não-redundantes correspondendo 139 
clusters_pdb_90\%) foram relacionados a deleções nas proteínas do PDB e 151 trechos (78 regiões de AS não-redundantes em 56 clusters_pdb_90\%) foram relacionados a inserções, totalizando 501 trechos indel (277 regiões de AS não-redundantes em 173 clusters_pdb_90\%) relacionados a eventos de AS dos tipos uso alternativo dos sítios de splice e retirada de exon. Esse dado foi utilizado para a análise de domínios estruturais (descritos no capítulo 5.1). Para as outras análises, somente as sequências que possuem a informação completa da região de AS na proteína PDB poderiam ser utilizadas.

Além disso, como o PDB é um banco de dados experimental, sendo que as sequências de formato FASTA (também conhecidas como sequências de resíduos SEQRES) são obtidas por um programa do próprio banco que utiliza a descrição dos aminoácidos cedida pelo autor da estrutura. Essa descrição muitas vezes diverge da descrição dos átomos (ATOM) presente nas estruturas protéicas. Isso ocorre porque alguns aminoácidos que compõe a sequência não são identificados experimentalmente devido a alta flexibilidade ou baixa resolução dessa região. Além disso, a numeração dos átomos dos aminoácidos adotada para os dados experimentais podem ser baseados em dados de homologia com outras proteínas, não sendo possível fazer uma comparação dessa região com outras sequências cuja homologia ainda não foi identificada. Para resolver esses problemas, nesse trabalho foi utilizado o banco de dados S2C - DUNBRACK (http://dunbrack.fccc.edu/Guoli/s2c/index.php), que possui uma tabela de consistência para as diferenças entre as sequências SEQRES e ATOM do PDB. Isso auxiliará diretamente os resultados do alinhamento das sequências de splicing alternativo com as estruturas protéicas porque permite utilizar a localização espacial precisa do evento de splicing alternativo. Após usar o programa S2C, que relaciona os resíduos sequenciais com os resíduos estruturais do $\mathrm{PDB}$, retiramos os casos em que não temos informação estrutural 
das regiões de AS, obtendo 355 trechos de deleções (179 regiões de AS não-redundantes em 124 clusters_pdb_90\%) e 117 trechos de inserções (75 regiões de AS não-redundantes em 53 clusters_pdb_90\%), totalizando 472 trechos indel (254 regiões de AS nãoredundantes em 155 clusters_pdb_90\%), utilizado nas demais análises.

Resumindo nosso pipeline, o primeiro passo é encontrar os casos de splicing descritos por bordas genômicas discordantes nos exons de um par de sequências (mRNA x mRNA ou mRNA x EST). Sabendo quais são os mRNAs e as ESTs que representam esses casos, essas sequências são alinhadas com as seqüências correspondentes às estruturas protéicas. O resultado desse alinhamento é re-processado para encontrar possíveis casos de splicing alternativo nas regiões $\mathrm{N}$ e C terminal das proteínas. Após esse realinhamento, verificamos as posições exatas das bordas de splicing alternativo através de uma comparação da informação da localização dessas bordas nas proteínas e nas sequências nucleotídicas traduzidas com a localização das bordas de splicing discordantes. Finalmente, consideramos somente aqueles casos em que a localização do evento de splicing alternativo nos RNAms corresponde exatamente a sua localização na estrutura protéica. 
4. Resultados 
Os nossos resultados foram obtidos a partir da relação entre as sequências nucleotídicas-protéicas para indicar a influência dos eventos de splicing alternativo sobre as estruturas de proteínas. Na maioria dos resultados foi complementado das análises foram comparadas as frequências das modificações estruturais em regiões associadas a AS e em outras regiões da proteína. Para deleções e inserções, as análises consideram as regiões flanqueadoras (bordas) dos eventos. Para os eventos de deleção também foram feitas análises considerando toda a extensão das regiões mapeadas na estrutura protéica.

As análises realizadas nesse trabalho tentam esclarecer as seguintes questões:

Para o dado inicial dos eventos de splicing alternativo:

- Qual a relação entre o tamanho dos eventos de splicing alternativo e sua frequência? (tópico 4.1);

Para eventos de AS mapeados a estruturas protéicas (inserções e deleções):

- Quais as estruturas secundárias são afetadas pelos eventos de splicing alternativo? (tópico 4.2);

- O contexto estrutural é importante para a inserção/deleção dos eventos de splicing alternativo? (tópico 4.4);

- Eventos de splicing alternativo estão relacionados a aminoácidos funcionais? (tópico 4.5);

Para eventos de AS mapeados a estruturas protéicas (somente deleções): 
- Qual é a complexidade das regiões de splicing alternativo (em termos de estruturas secundárias)? (tópico 4.3);

- Quão próximo o evento de splicing alternativo está dos sítios de ligação da proteína? (tópico 4.6);

- Bordas de splicing alternativo estão espacialmente mais próximas na estrutura protéica? (tópico 4.7);

- As regiões de splicing alternativo fazem mais interações inter-residuais que outras regiões da proteína? (tópico 4.8). 


\subsection{Qual é a relacão entre o tamanho dos eventos de splicing}

\section{alternativo e sua frequência?}

A relação entre o tamanho dos eventos e sua frequência nos informa sobre as características específicas dos tamanhos de cada tipo de evento de splicing alternativo aqui estudado. Em cada par de transcritos para os quais foram descritas bordas com sequências genômicas conflitantes, o que corresponde a um evento de AS, calculamos a diferença de tamanho entre essas bordas a fim de obter a distribuição de tamanho dos diferentes tipos de eventos de AS (AU, ES e IR).

Nas figuras a seguir os nossos resultados mostram as distribuições de tamanho para os eventos de AU, ES e IR e para a soma desses eventos. Os gráficos log-log demonstram a frequência de cada tamanho de evento de AS para os diferentes tipos de evento. Nesse gráfico, quando observamos um espalhamento dos pontos em determinada frequência, isso significa que poucos casos são encontrados para esse tamanho, ou seja, ele é um tamanho com pouco frequente nesse tipo de evento de AS. Da mesma forma, quando observamos um ponto com alta frequência, isso significa que temos muitos casos para aquele tamanho, ou seja, esse tamanho é comum nesse tipo de evento de AS. 
A

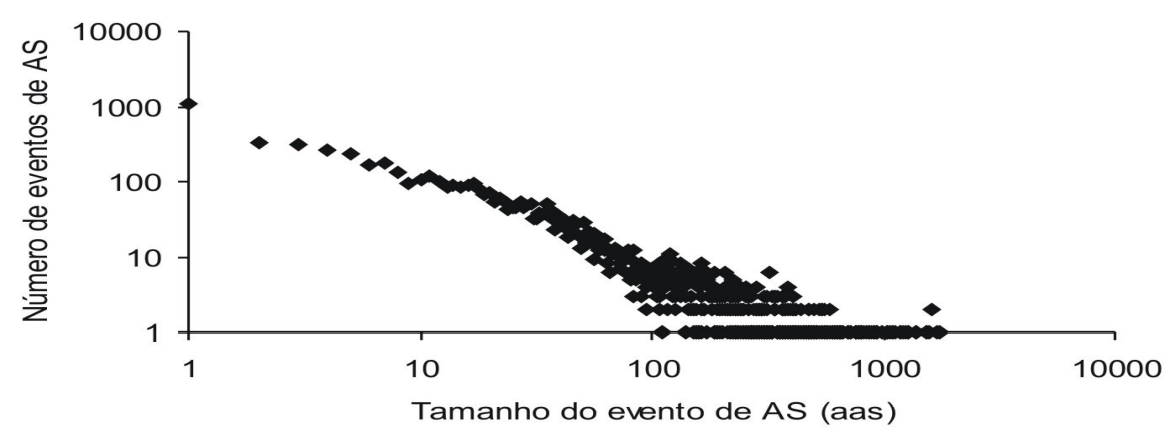

$\mathrm{B}$
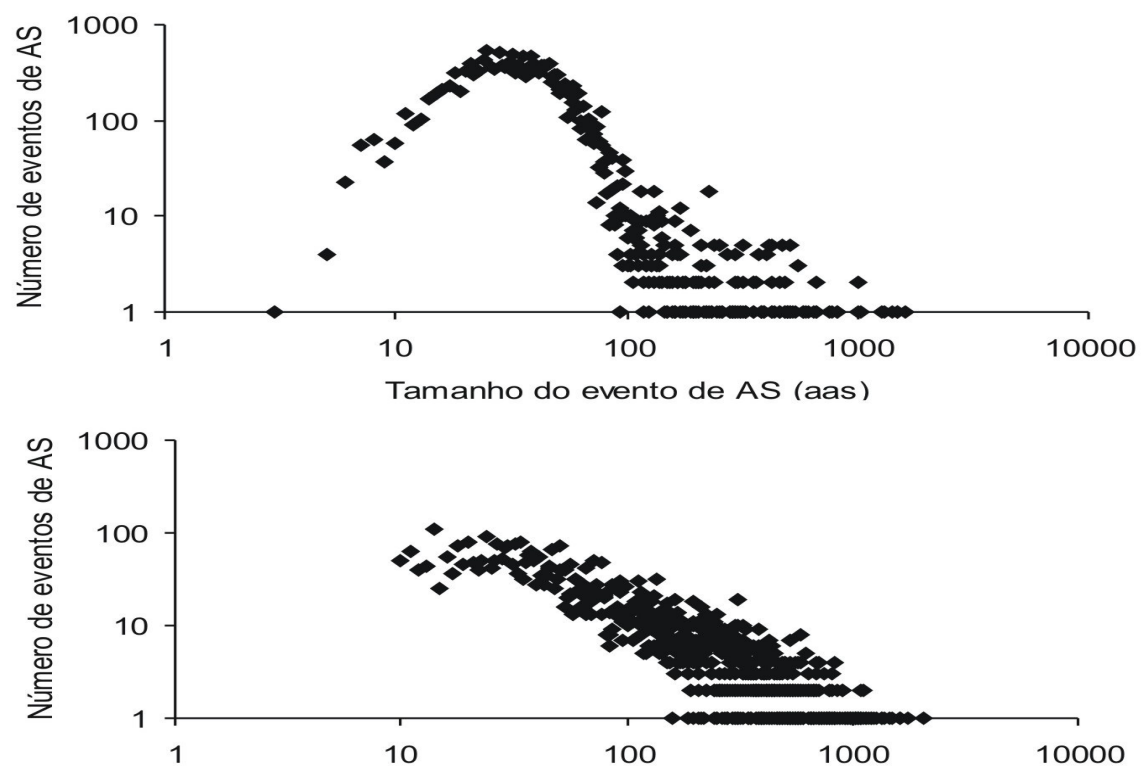

$\mathrm{D}$

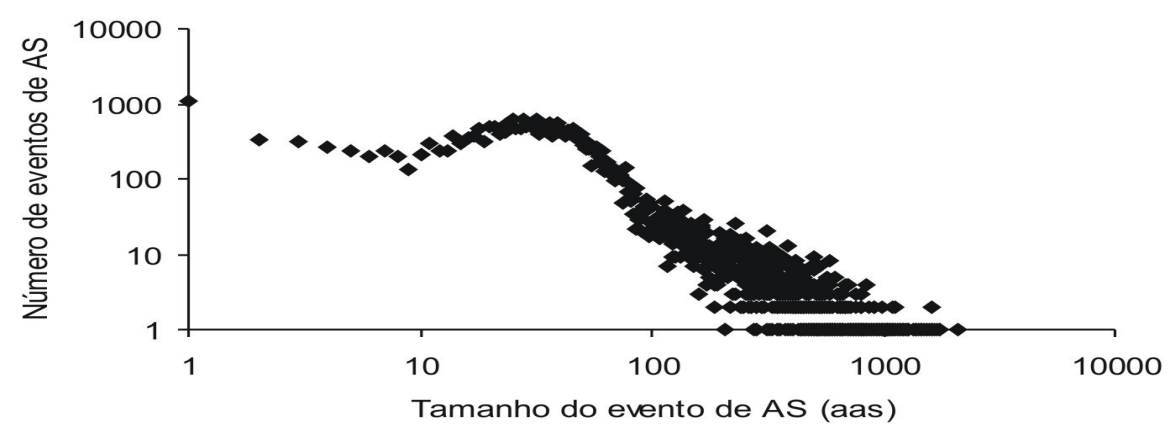

Figura 4.1.1 Gráficos log-log da frequência do tamanho dos eventos de AS. A. Uso alternativo dos sítios de splice (AU); B. Retirada de exons (ES); C. Retenção de íntrons (IR); D. Soma da frequência dos eventos anteriores (AU + ES + IR).

Na figura 1.1.A. temos a distribuição de tamanho para os eventos de AS do tipo AU. É possível verificar que casos menores possuem uma alta frequência e que essa vai 
diminuindo a medida em que o tamanho do evento aumenta. Essa curva reflete o comportamento desse tipo de evento, que faz a inclusão/exclusão parcial de um exon ou um íntron. Como pode ser visto na figura, quanto menor o tamanho da inclusão/exclusão de uma sequência exônica/intrônica, maior é a sua frequência e, a medida em que essa sequência de amino ácidos que é incluída/excluída aumenta de tamanho, mais raro torna-se o evento de AU.

Podemos verificar que para ES (figura 1.1.B) há um aumento na frequência dos eventos até aproximadamente 30-80 aas. A partir desses valores, há a diminuição do número de casos a medida em o tamanho do evento aumenta. Lembrando que o tamanho médio de exons humanos é 120 nt, cerca de 40 aas, essa curva demonstra que há um maior número de casos para valores próximos a esse tamanho, como esperado para casos de retirada de exons (ES). Sequências de amino ácidos maiores ou menores que 40 aas vão tendo uma menor frequência, ou seja, tornam-se cada vez mais raros.

A figura 1.1.C. mostra a mesma análise feita para IR, na qual podemos verificar que a curva se incia em 10 aas. A partir desse tamanho de sequência de aas inserida/excluída, podemos verificar que a curva apresenta um espalhamento, indicando o comportamento dos eventos de IR, em que não existem muitos casos para cada tamanho de AS. Além disso, a frequência dos eventos vai gradualmente diminuindo até 120 aas. Esse resultado pode ser justificado por trabalhos anteriores que citam uma restrição no tamanho do íntron que é retido no genoma humano [Sakabe (2007)]. Após esse tamanho, os eventos tornam-se cada vez mais raros.

Finalmente, na figura 1.1.D. temos a distribuição do tamanho de todos os tipos de eventos de AS utilizados nesse trabalho (AU, ES e IR). Analisando essa curva podemos verificar que há uma predominância dos dados de AU até 10 aas, com um máximo em 
torno de 50 aas principalmente devido ao dado de ES. Após esse tamanho há um declive, visto em todos os tipos de eventos de AS. Nota-se que nos eventos de IR, a curva termina um pouco depois (120 aas) do que nos outros tipos de eventos de AS (100 aas). Isso é esperado, uma vez que íntrons são maiores que exons e que, como dito anteriormente, o tamanho dos íntrons retidos é restrito no genoma humano. Enquanto nossos resultados estavam sendo analisados, Wang e colaboradores [Wang (2005)] fizeram uma análise equivalente, como pode ser visto na figura a seguir:

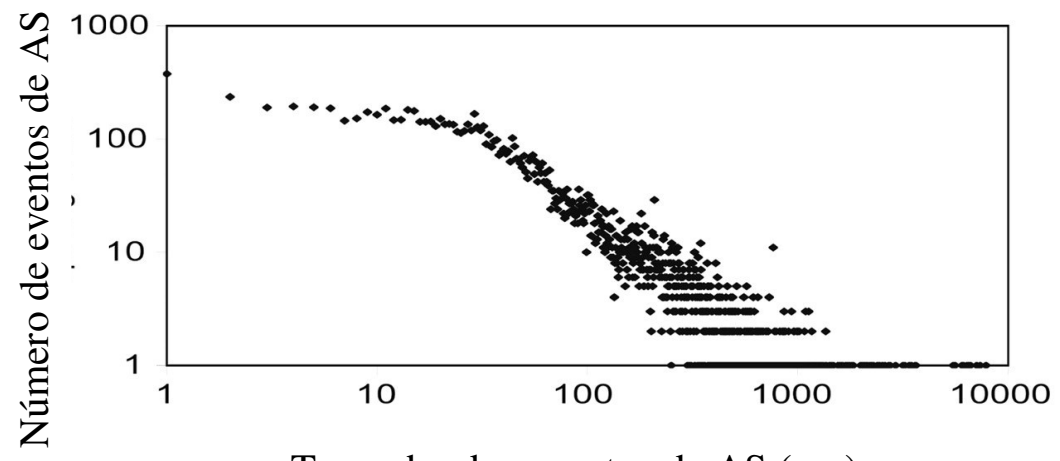

Tamanho dos eventos de AS (aas)

Figura 4.1.2 Gráfico log-log da frequência de casos de splicing alternativo de acordo com o tamanho do splicing (figura adaptada de Wang (2005)]).

Nesse trabalho, os autores descrevem que o tamanho dos eventos de AS segue a "lei de força", uma polinomial que relaciona duas variáveis e tem como característica a invariância de escala, ou seja, não há mudança no gráfico se o ambas escalas forem multiplicadas por um fator comum. Esse dado engloba 8,220 sequências protéicas com isoformas de AS (não necessariamente relacionadas a estruturas) de ratos, camundongos e humanos disponíveis no banco de dados de sequência protéicas SWISS-PROT com 
anotação para variantes de AS (SWISS-PROT_VAR). É feita uma ressalva no próprio trabalho, porém, de que a lei só se aplica a eventos maiores que 20 aas sendo que, abaixo desse tamanho, a quantidade de eventos de AS segue uma distribuição uniforme. Uma explicação dada para essa diferença de comportamento da curva para eventos maiores e menores que 20 aas é que a distribuição dos eventos maiores que 20 aas está de acordo com o tamanho de exons "constitutivos", que seguem uma distribuição normal e seriam casos mais raros. A distribuição uniforme estaria de acordo com a distribuição de exons alternativos, em que tamanhos menores são mais frequentes.

Comparando nossas análises com a distribuição apresentada por Wang, podemos inferir que uma outra explicação plausível para a distribuição do gráfico 4.1.2, além da quantidade de casos de exons alternativos, poderia ser um enriquecimento de eventos do tipo AU e pequenos eventos do tipo ES. Como não é visto nenhum aclive após os primeiros 20 aas, podemos considerar também que há poucos casos de ES e de IR de tamanhos maiores que esse (de 20 a 50 aas).

No trabalho de Wang não foi mostrado o gráfico da distribuição de tamanho dos casos relacionados a estruturas protéicas o que seria muito interessante uma vez que, das 8,220 sequências protéicas de ratos, camundongos e humanas, são encontradas somente 351 estruturas protéicas relacionadas a eventos de splicing alternativo.

Outros trabalhos também descreveram a distribuição do tamanho dos casos de AS e sua frequência, como Yura e colaboradores [Yura, (2006)]. Nele, 76\% dos casos de AS que modificam o tamanho da proteína resultante (inserção ou deleção) possuem menos que 100 amino ácidos. O gráfico da frequência apresentado nesse trabalho é baseado no total de casos de AS que podem ser associados a proteínas (3,181 loci), não ao total de casos associados a estruturas protéicas (429 isoformas, 219 variantes em 242 regiões de AS). 
Portanto, após demonstrar a distribuição do tamanho dos eventos de AS no nosso dado inicial e na literatura, decidimos refazer esse gráfico somente com os nossos dados de eventos de splicing alternativo relacionados a estruturas protéicas no PDB (alinhamentos com mais que $90 \%$ de identidade recalculada, descrito nos métodos), como pode ser visto a seguir:
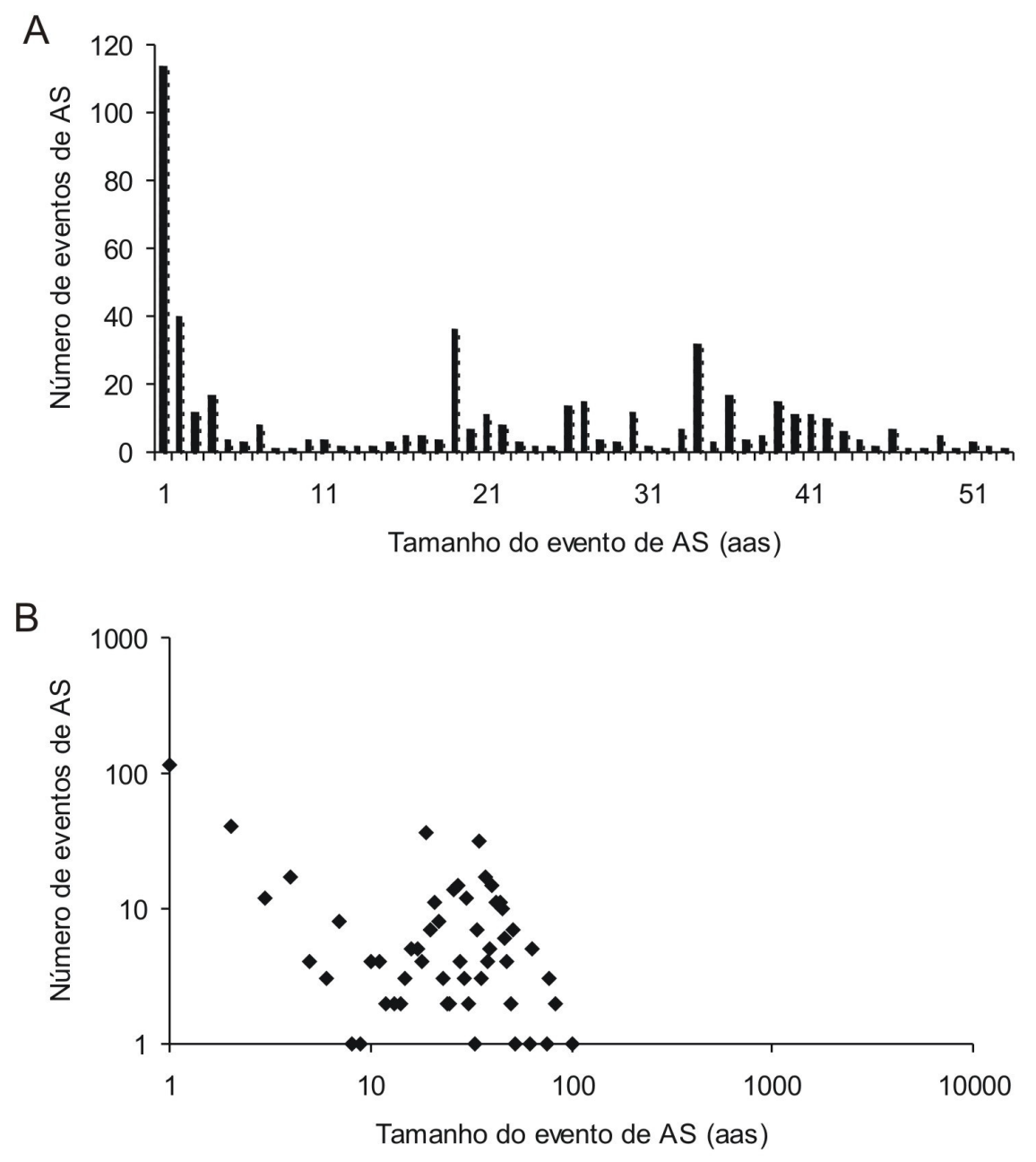

Figura 4.1.3. A. Frequência dos tamanhos de eventos de AS mapeados a estruturas protéicas; B. Gráfico log-log da frequência dos tamanhos de eventos de AS mapeados a estruturas protéicas (ambos os gráficos descrevem casos com mais de 90\% de identidade no alinhamento, como descrito nos métodos dessa tese) . 
Comparando esse gráfico (4.1.3) com aqueles vistos anteriormente (4.1.1) para a distribuição do tamanho dos tipos de eventos de AS, não é possível identificar nenhum dos tipos de eventos de AS nessa curva. Isso ocorre devido a pequena quantidade de casos em que o AS está altamente relacionado a estruturas protéicas: 501 regiões de AS em 376 estruturas protéicas, quantidade semelhante aquelas verificadas em outros trabalhos [Wang (2005), Yura (2006)]. Esse resultado nos indica que a quantidade de casos de AS relacionados a estruturas protéicas é muito pequeno quando comparado a quantidade de casos de AS mapeados no genoma. Dessa forma, não foi possível identificar nenhum dos tipos de eventos de AS sendo representados por estruturas protéicas, o que não nos permite estudar separadamente as estruturas protéicas relacionadas a cada tipo de evento. Além disso, como pode ser visto no gráfico 4.1.3.A, eventos com tamanho muito pequeno (1-2 aas) estão altamente representados. Esses eventos não foram excluídos de nossas análises porque eles realmente são vistos com alta frequência em eventos do tipo $\mathrm{AU}$, como pode ser visto no gráfico 4.1.1.A. Também são descritos trabalhos em que esse tipo de modificação não é considerado ruído, sendo que a variação de sítios de splice doadores e aceitadores muito próximos podem ocorrer para modular finamente a estrutura de proteínas pela adição/remoção de um aminoácido [Zavolan (2003), Chern (2006)]. 


\subsection{Quais estruturas secundárias são afetadas pelos eventos de $\underline{A S ?}$}

Uma vez que as regiões de AS estão mapeadas em estruturas protéicas, a primeira análise realizada foi verificar quais estruturas secundárias são encontradas nas bordas das regiões inseridas e deletadas. Para a deleção, também é possível verificar a quantidade e a complexidade (variações de estrutturas secundárias em uma região de AS) das mesmas.

Iniciamos nossas análises revendo as quantidades de estruturas secundárias encontradas nas proteínas humanas do PDB. Para assegurar a retirada da redundância desse dado, realizamos duas análises: uma retirando as sequências idênticas (3.961 cadeias protéicas com 753.660 aas) e outra utilizando somente com a sequência de maior tamanho de cada agrupamento (cluster_pdb_90\%), totalizando 1.651 cadeias protéicas com 352.693 aas. As regiões com estrutura secundária indefinida ou com estruturas secundárias do tipo volta (turn, loop) foram englobadas na denominação coil e/ou voltas.

Ambos resultados apresentaram-se muito parecidos: 52-53\% de estruturas do tipo coil (C), $18 \%$ de estruturas em folha (E) e $28-29 \%$ de estruturas em hélice (H). A fim de verificar se as proteínas relacionadas a eventos de AS apresentavam algum viés, veridicamos a porcentagem de estruturas secundárias dessas proteínas e observamos o mesmo resultado obtido para todas as proteínas do PDB. Podemos então inferir que a distribuição de amino ácidos nas proteínas relacionadas a AS não é diferente das outras proteínas do PDB e, portanto, poderíamos utlizar todas as proteínas do PDB para observar das características estruturais de trechos de AS. 
A distribuição dos tipos de estrutura secundária encontradas no PDB são utilizados como o "esperado" nas nossas análises estatísticas. Os nossos resultados estão resumidos na tabela a seguir:

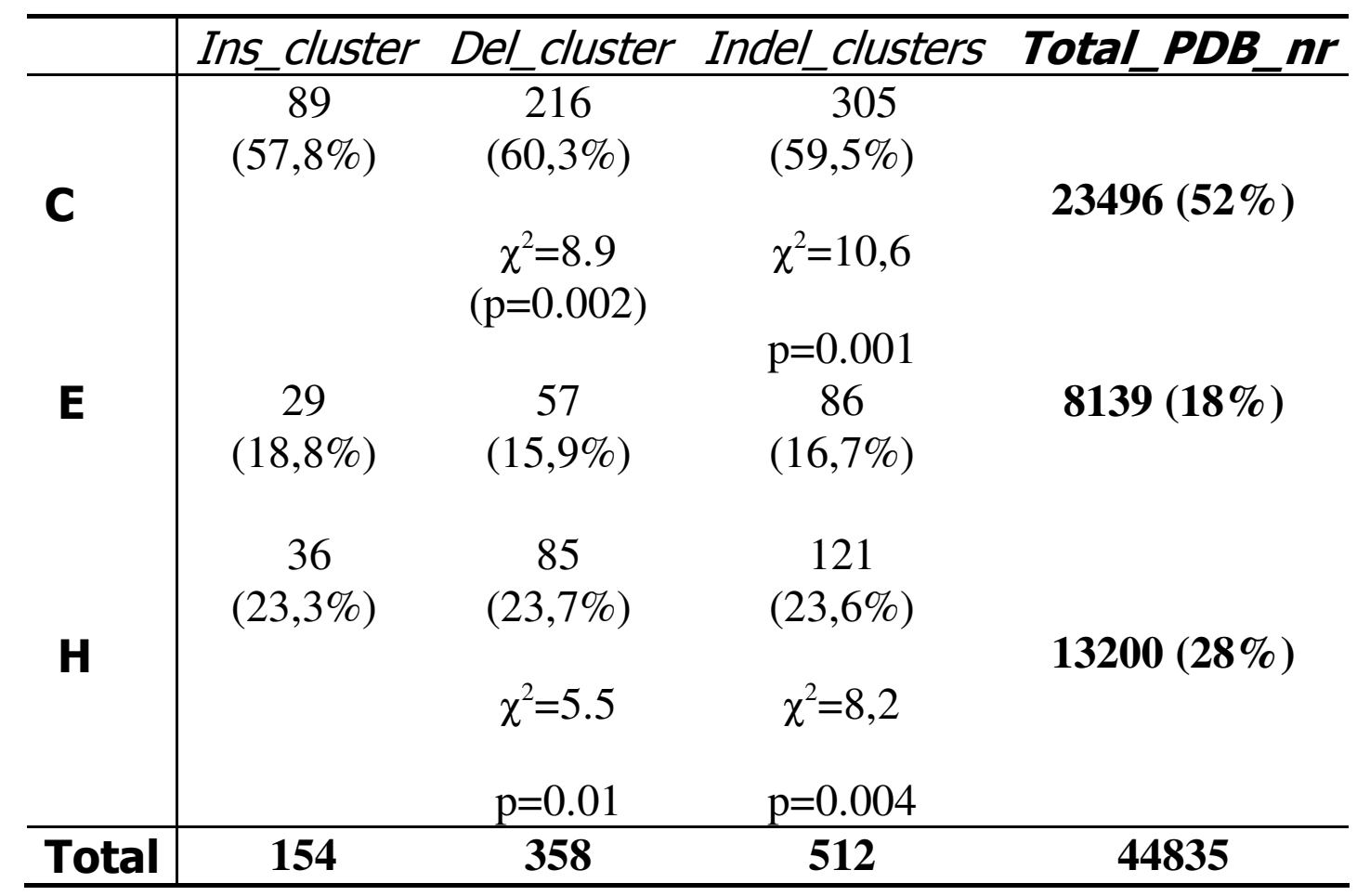

Tabela 4.2.1 - Descrição das estruturas secundárias encontradas $(\mathrm{C}=$ coil, $\mathrm{E}=$ folha e $\mathrm{H}=$ hélice) nas bordas das regiões de inserção, deleção e indels. O total_PDB_nr foi calculado a partir da quantidade de aminoácidos de proteínas relacionadas a AS (somente aquelas com o maior tamanho de cada cluster_pdb_90\%) encontradas no PDB. A análise estatística foi realizada utilizando o teste $\chi^{2}$.

Comparando a quantidade de estruturas secundárias nas bordas de AS (observado) com a quantidade de estruturas secundárias esperadas, foi possível verificar algumas diferenças estatisticamente significantes. Para as bordas de deleção há um aumento nos casos de "coil" (52\% esperado, $60 \%$ observado). Também foi verificada uma menor quantidade de hélices nessas bordas ( $28 \%$ esperado, $23,7 \%$ observado). Não foram vistas 
diferenças entre a quantidade de estruturas secundárias observadas/esperadas nas bordas de inserção. A modificação das quantidades de estruturas nas bordas de deleção estão refletidas nos valores de indel, em que há um aumento estatisticamente significante na quantidade de coils assim como uma diminuição significativa na quantidade de hélices.

Como as voltas (coil) sáo vistas com uma maior frequëncias nas bordas de AS de deleção, usamos o DSSP para procurar outros tipos de volta mais comuns. Porém, visto que praticamente todas as voltas eram do tipo "beta", caracterizada por pontes de hidrogênio a cada 3 resíduos (que é a forma mais comum de volta em proteínas) não sendo encontradas diferenças entre os tipos de volta nas bordas em relação ao resto da proteína. Utilizamos então a distribuição das categorias de estruturas secundárias (com exceção de hélices (H) e folhas estendidas (E)) classificadas pelo STRIDE, que separa as outras estruturas secundárias em 6 categorias: coil (C), 3-hélice ou 3/10 hélice (G), 5-hélice ou pi hélice (I), volta de ligação de hidrogênio (T), ponte (S) e folha estendida (B). 

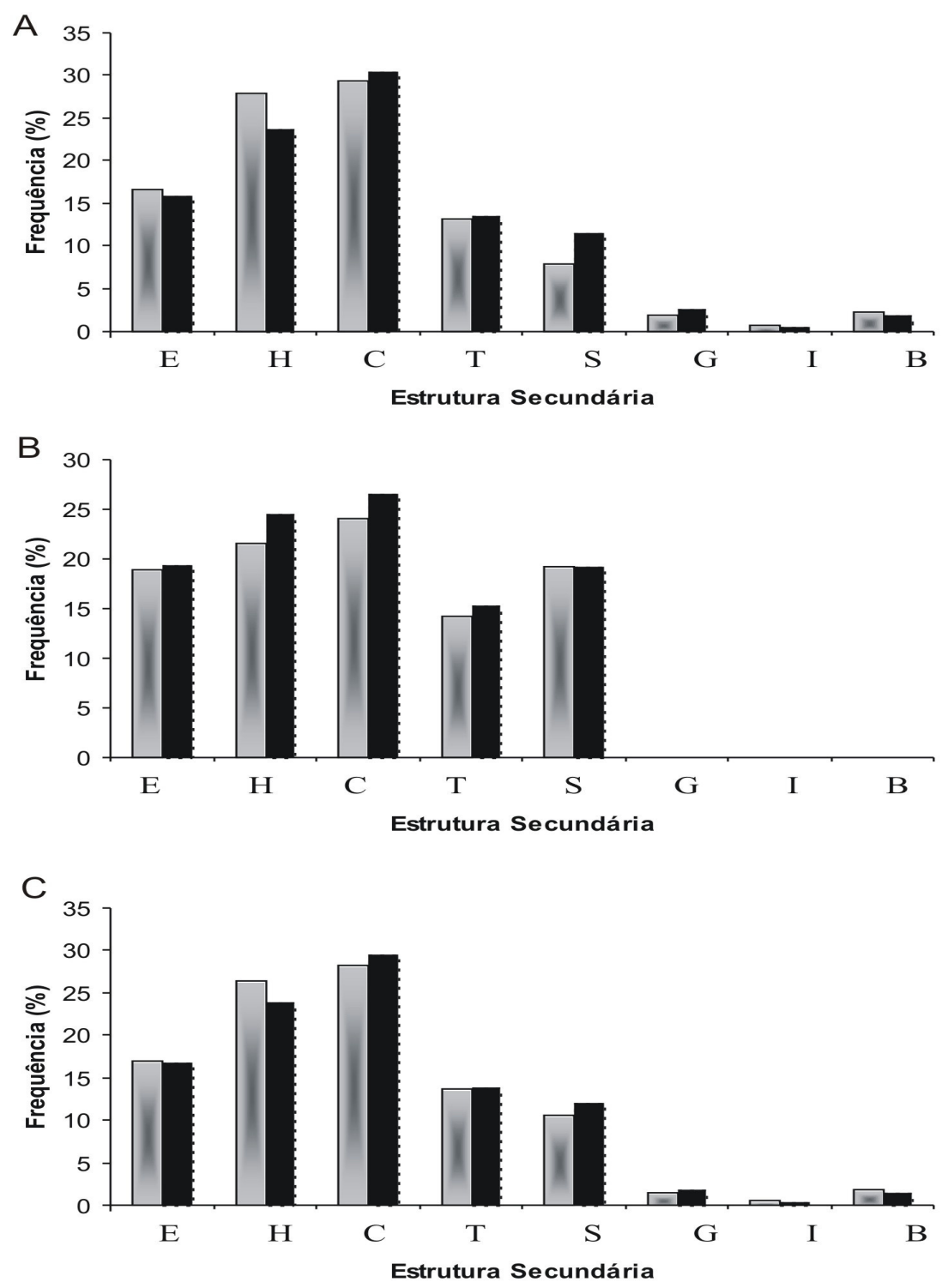

Figura 4.2.2 - Frequência (em porcentagem) das estruturas secundárias encontradas nas bordas das regiões de: A. deleções; B. Inserções e C. indels. Barras cinzas são as bordas de AS e barras pretas são as proteínas não-redundantes relacionadas a AS agrupadas (cluster_pdb_90\%).

Como está representado na figura 4.2.2, analisando o detalhamento das estruturas secundárias de voltas dado pelo programa, não foi possível identificar diferenças 
significativas entre a distribuição dessas estruturas ao longo das proteínas e nos dados das bordas de inserções, deleções e indels. Isso indica que, apesar de possuir um aumento na quantidade de estruturas secundárias do tipo coil nas bordas de deleção, não existe preferência por nenhum tipo específico de volta (coil) nessas bordas e nem nas bordas de inserções e indels.

A distribuição das estruturas secundárias das bordas de splicing em inserções, deleções e substituições também foi realizada por outro grupo de pesquisa [Wang (2005)]. Em seus resultados, verificou-se que a maioria das bordas flanqueadoras estão em regiões de volta (coil), alfa-hélices e folhas-beta, respectivamente, tanto para casos de inserção quanto para casos de deleção. Porém, os únicos casos estatisticamente relevantes $(\mathrm{p}<0.001)$ foram verificados em deleções, com uma maior quantidade das bordas em coil (42\% esperado e $60 \%$ observado) e uma menor quantidade das bordas em hélices ( $41 \%$ esperado e $26.5 \%$ observado). Os $17 \%$ esperados para os casos de folhas não mostraram-se estatisticamente significantes comparados aos outros valores.

O resultado apresentado por Wang como esperado foi de $42 \%$ para coil, $17 \%$ para folhas e $42 \%$ para hélices. Entretanto, as quantidades de aminoácidos esperados nos nossos resultados, apresentam uma maior quantidade de coils (52-53\%) e menor de hélices (2829\%). Se esse valor esperado de distribuição de estruturas secundárias do nosso dado fosse utilizado nos dados de Wang, seria observado um aumento de estruturas do tipo coil estatisticamente significativo nos dados de AS em relação ao esperado. Entretanto, as estruturas do tipo hélice não apresentariam diferenças estatisticamente significantes entre o esperado (28-29\%) e o observado nas bordas de AS (26.5\%). Não foi encontrada nenhuma 
explicação plausível para a diferença entre a distribuição de estruturas secundárias nos aminoácidos das estruturas do PDB e do trabalho de Wang e colaboradores.

Portanto, os nossos resultados das bordas de deleção indicam uma tendência dessas bordas estarem em regiões pouco estruturadas, demonstrado nas bordas de deleção pelo aumento de estruturas do tipo coil pela diminuição da quantidade de bordas em hélices. As bordas de inserção não apresentaram diferenças estatisticamente significantes em relação ao resto da proteína, o que pode ocorrer devido a pequena representação desses casos.

O fato das bordas de deleção preferirem regiões desestruturadas poderia indicar que as regiões de AS não têm preferência por estruturas secundárias definidas. Analisando as estruturas secundárias dentro das regiões de AS, encontramos $20 \%$ (48/248) delas compostas somente por coils, indicando que, apesar das bordas de deleções serem pouco estruturadas, isso não siginifica que as regiões de AS também serão desestruturadas, havendo estruturas secundárias como folhas e hélices sendo retiradas dessas estruturas nas isoformas de splicing, o que poderá modificar significantemente a estrutura protéica. 


\subsection{Qual é a complexidade das regiões de splicing alternativo (em termos de estrutura secundária)?}

Para verificar a diversidade de estruturas secundárias das regiões de AS deletadas, foram vistos quantos tipos de estrutura secundária ordenadas podem ser encontradas ao longo de um trecho de AS que é retirado da proteína, como está exemplificado na figura a seguir:

A.

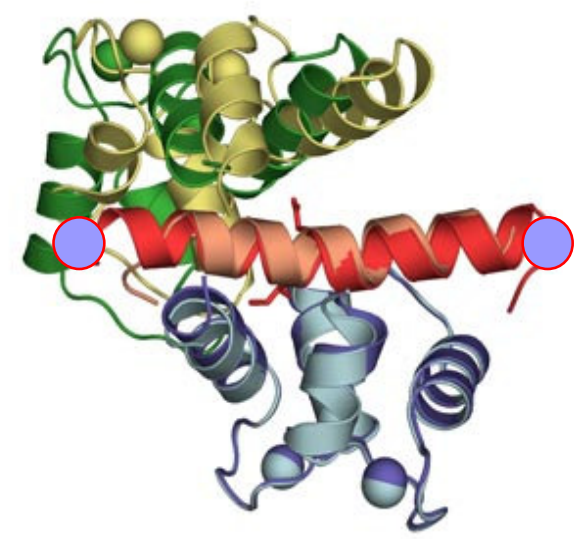

B.

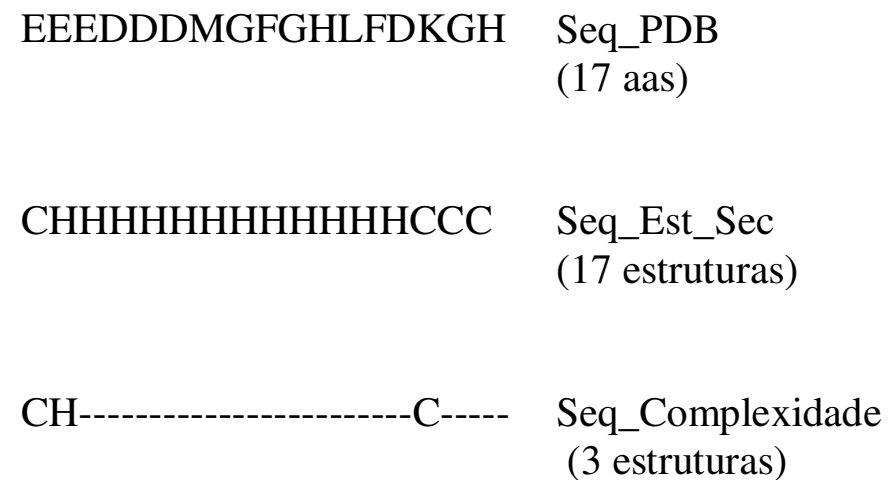

Figura 4.3.1 - A. Ilustração do trecho deletado na estrutura protéica. B. Demonstração da sequência correspondente ao trecho deletado (Seq_PDB) com 17 amino ácidos, a estrutura secundária que esse trecho possui (Seq_Est_Sec) com 17 estruturas secundárias mapeadas e a simplificação dessa estrutura para a medida de diversidade de estruturas secundárias na proteína (Seq_Complexidade) agora com 3 estruturas.

Nesse trabalho, os termos diversidade e complexidade foram utilizados para a combinação de estruturas secundárias em determinado trecho de amino ácidos. A fim de 
encontrarmos a diversidade estrutural de cada região de AS, foi relizado o procedimento descrito a seguir. Inicialmente, as estruturas secundárias foram mapeadas as regiões de AS de diferentes tamanhos. Para cada posição da sequência de AS, verificamos se a estrutura secundária naquela posição é diferente da estrutura secundária da posição anterior. Quando a estrutura secundária é diferente, somamos 1 a quantidade total de diversidade. Quando a estrutura é idêntica a posição anterior, nada é somado. A quantidade total de diversidade é então determinada pela quantidade de estruturas secundárias que não são sequencialmente repetidas em cada trecho, como mostrado na figura 4.3.1. Essa análise foi feita considerando duas classificações de estruturas secundárias: do PDB (C, E e H) e do STRIDE (C, E, H, T, S, B, G, I).

Após verificar a quantidade total de diversidade, relacionamos esse valor ao tamanho do evento de AS, como pode ser visualizado a seguir: 
A.

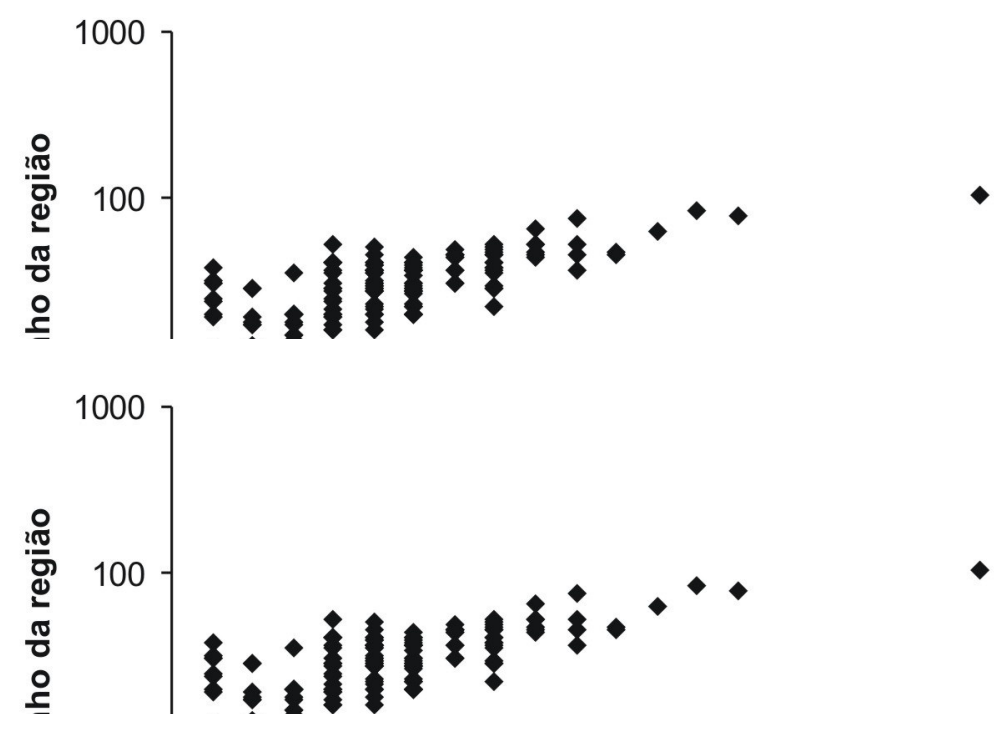

B.

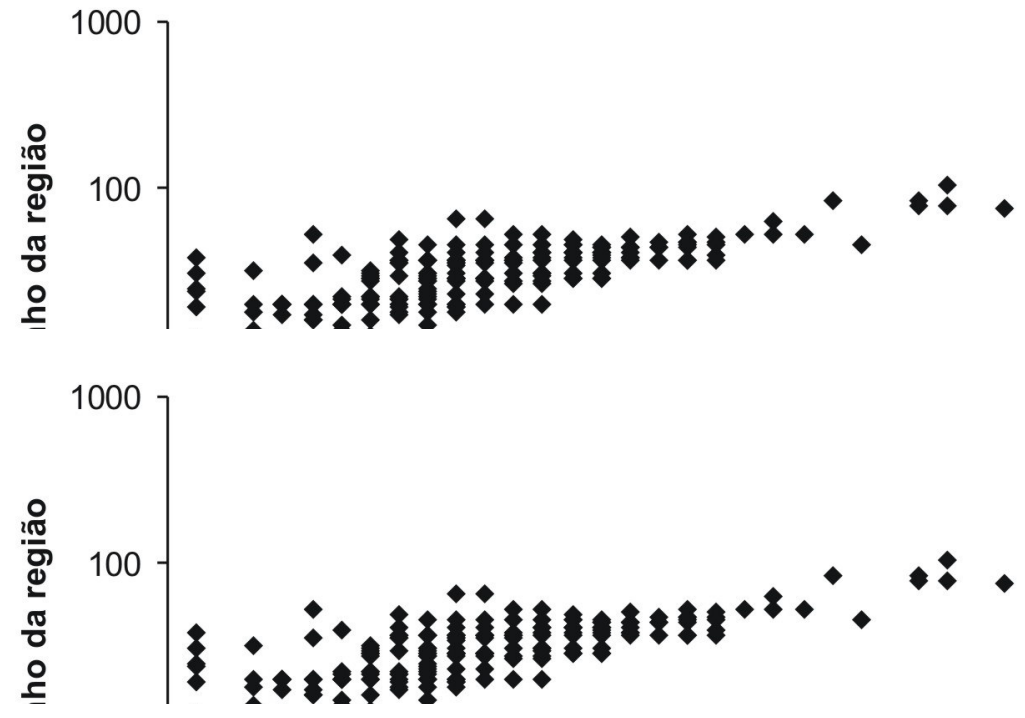

Figura 4.3.2 - Gráfico log da combinação de estruturas secundárias de acordo com o tamanho da região A. para a classificação do PDB e B. para a classificação do DSSP.

Analisando esses gráficos podemos observar que, tanto para deleções pequenas como para deleções maiores, podem existir uma ou mais combinações de estrutura 
secundária. Podemos exemplificar esse fato comparando a quantidade total de diversidade para regiões de 20 aminoácidos. Nessas regiões são encontradas de três a doze combinações de estruturas secundárias, como pode ser visualizado nas estrutras na figura 4.3.3.

A.

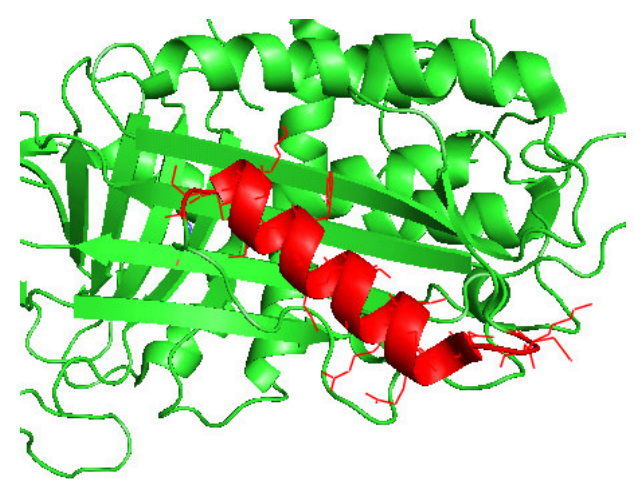

B.

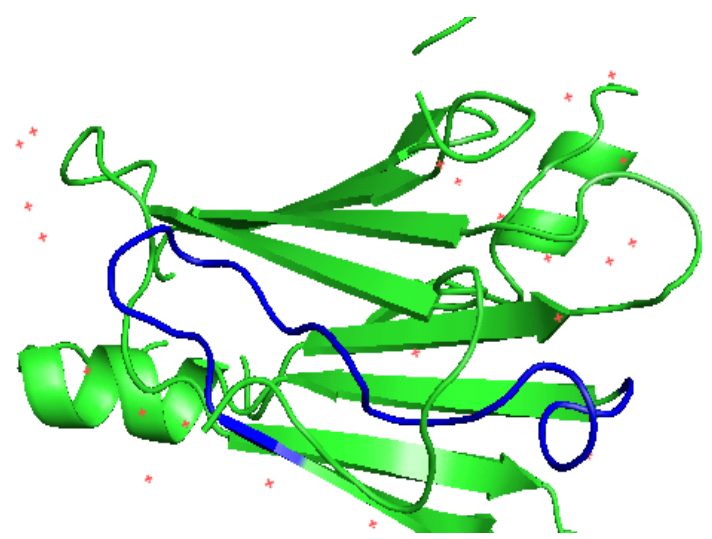

Figura 4.3.3 - Visualização da combinação de estruturas secundárias (DSSP / STRIDE) para regiões de 20 amino ácidos com A. 3 combinações de estrutura secundária (transtirretina = "transthyretin" (1bz8_A)) e B. 15 combinações de estrutura secundária (complexo antitrombina - trombina - heparina = "antithrombin-thrombin-heparin complex"(1tb6_I)).

A partir dos resultados da figura 4.3.2, resolvemos investigar como qual é frequência de combinações de estruturas secundárias dos trechos modificados por AS. Verificamos que os casos mais frequentes de deleção de AS em proteínas possuem até 2 tipos de estruturas secundárias para ambas as classificações (PDB/STRIDE). Para a classificação do PDB, mais simplificada, verificamos que existe um outro máximo entre 56 combinações e combinações maiores que 10 estruturas quase não são encontradas. Para a 
classificação do STRIDE, notamos que esse outro máximo ocorre entre 9-10 combinações e combinações maiores que 15 aminoácidos quase não são encontrados. A diferença entre os valores da classificação do PDB e do STRIDE pode ser justificada pela diversa classificação dos casos de volta no STRIDE, o que não ocorre no PDB. A partir desse resultado, poderíamos dizer que as regiões de AS tem tendências a dois tipos de diversidade estrutural, de trechos com 2 tipos de estrutura ou de trechos com 5-6 tipos de estrutura.

Entretanto, esse resultado pode somente indicar que a quantidade de combinações encontradas em um trecho retirado da proteína é restrita ao tamanho dessa sequência ou é restrita ao tamanho de cada um dos trechos de estrutura secundária da proteína. Para afirmarmos se os trechos de deleção realmente têm preferência por combinações com poucas estruturas secundárias (chamadas aqui de simples), normalizamos a quantidade de estruturas secundárias pelo tamanho do trecho deletado. Com essa normalização, obtemos os seguintes gráficos: 

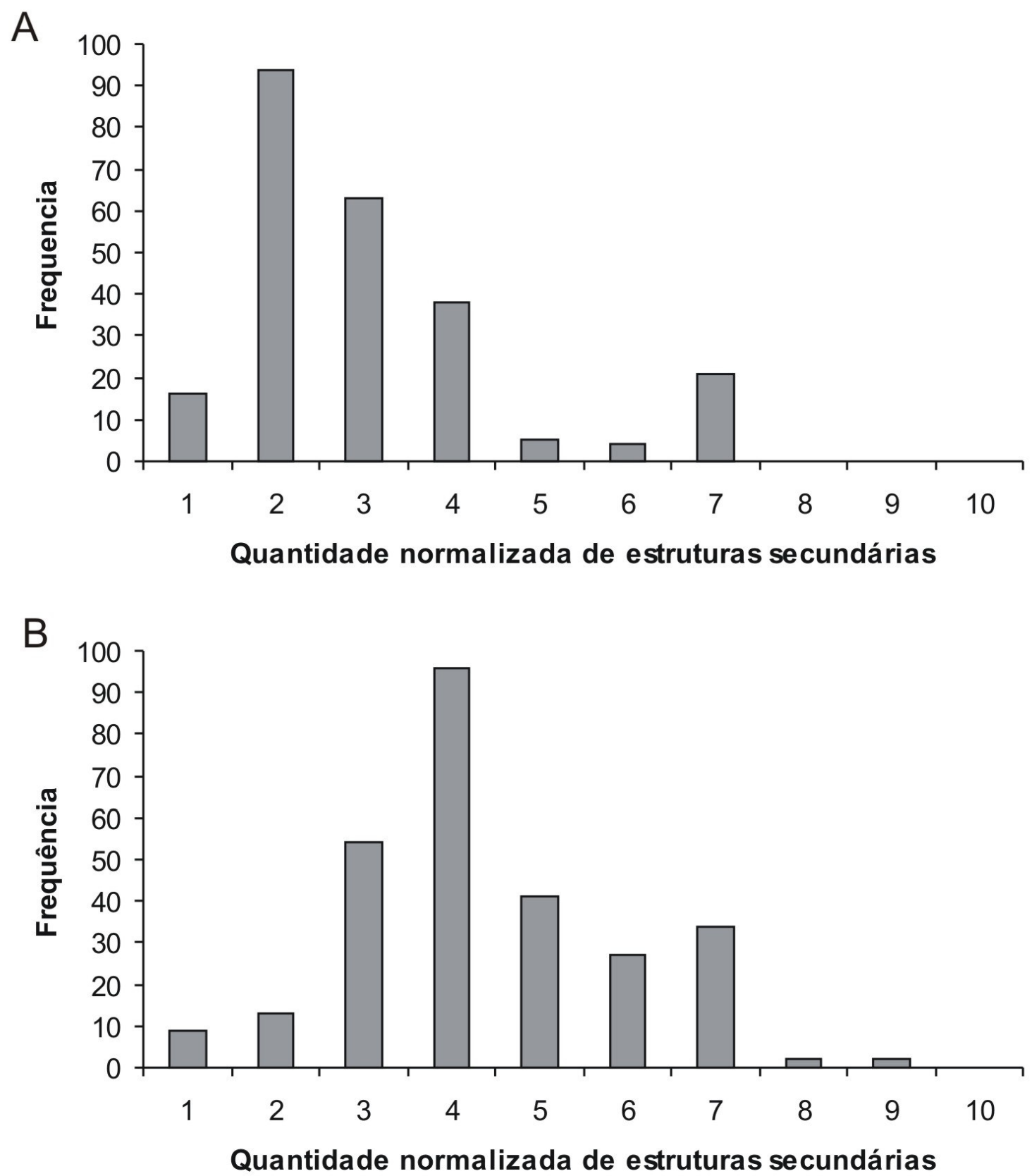

Figura 4.3.4 - Frequência da quantidade de estruturas secundárias normalizada pelo tamanho da deleção em: A. PDB e B. STRIDE.

Podemos verificar que, considerando somente a classificação de estruturas secundárias do $\mathrm{PDB}(\mathrm{C}, \mathrm{E}$ e $\mathrm{H})$, a diversidade mais frequente (cerca de $80 \%$ ) ocorre em trechos com 2 a 4 estruturas secundárias. Quando consideramos a classificação do STRIDE 
(com 8 tipos de estrutura secundária), também verificamos uma maior concentração de casos de combinações de estrutura simples (cerca de 60\%), contendo de 3 a 5 tipos de esturutra secundária em cada trecho. Ou seja, podemos dizer que os trechos de deleção de AS em proteínas apresentam diversidade de estruturas secundárias, porém tem uma preferência por combinações mais simples, com pouca complexidade, preferencialmente com duas ou três estruturas secundárias diferentes. 


\subsection{O contexto estrutural (domínios estruturais) é importante para insercãa e/ou deleção de eventos de splicing alternativo?}

Como dito anteriormente, domínios estruturais são regiões que se enovelam independentemente e podem ser subdivididos em classes e arquiteturas. Nessa análise, verificamos se as regiões associadas a AS encontravam-se em domínios estruturais, especialmente aqueles descritos pelo CATH (versão 3.0). Calculamos a distribuição desses domínios estruturais (classes e arquiteturas) em trechos de AS e comparamos essa distribuição com aquela encontrada nas proteínas humanas.

Inicialmente, verificamos a frequência de inserção/deleção das regiões de AS nos domínios estruturais associadas as mesmas. Nas análises da distribuição de domínios estruturais em estruturas protéicas associadas a AS, novamente ressaltamos o tratamento dado para a retirada da redundância. Foi possível observar que, quando comparamos a quantidade de regiões de AS das estruturas protéicas mapeadas (ambas as bordas inseridas em um domínio) a domínios estruturais em deleções, 72\% (140/175) dos casos nãoredundantes estão dentro dos domínios. Nos casos com inserção, os dados em que foi retirada a redundância correspondem a 79\% (62/78).

A seguir apresentamos os trechos de AS mapeados nas classes de domínios estruturais do CATH: 


\begin{tabular}{|c|c|c|c|c|}
\hline Classe & Ins_cluster & Del_cluster & Indel_cluster & Todo Cath \\
\hline 1 (alfa) & $15(24.1 \%)$ & $\begin{array}{l}25(17.8 \%) \\
p=0.08\end{array}$ & $40(19.8 \%)$ & $413(25 \%)$ \\
\hline 2 (beta) & $\begin{array}{l}30(48.3 \%) \\
p=0.02\end{array}$ & $51(36.4 \%)$ & $81(40 \%)$ & $565(34.3 \%)$ \\
\hline 3 (alfa;beta) & $\begin{array}{l}16(25.8 \%) \\
p=0.06\end{array}$ & $\begin{array}{l}64(45.7 \%) \\
p=0.08\end{array}$ & 80 & $628(38.1 \%)$ \\
\hline $\begin{array}{l}4 \text { (estruturas } \\
\text { secundárias) }\end{array}$ & $1 \quad(1.6 \%)$ & $\begin{array}{l}0 \\
p=0.07\end{array}$ & $\begin{array}{l}1 \\
p=0.07\end{array}$ & $41 \quad(2.4 \%)$ \\
\hline Total & 62 & 140 & 202 & 1647 \\
\hline
\end{tabular}

Tabela 4.4.1 - Distribuição das classes de domínios estruturais relacionados a eventos de AS. Entre parênteses a proporção, em itálico o p-value do teste de Fisher comparado ao total de domínios humanos não-redundantes do CATH.

Nessa tabela, podemos verificar que as inserções possuem uma tendência a ocorrer mais em domínios to tipo beta e menos em domínios do tipo alfa;beta do que o esperado. As deleções tendem a ocorrer menos em domínios do tipo alfa, mais em domínios do tipo alfa;beta e menos em de estruturas secundárias do que o esperado. Porém, quando unimos os resultados do mapeamento das bordas de inserção e deleção (indels), não observamos tendências estatisticamente significantes $(\mathrm{p}<0.001)$ para nenhuma classe de domínios. Entretanto, como mesmo sem haver tendências para determinadas classes podem haver tendências para determinadas arquiteturas, verificamos a distribuição das arquiteturas nas quais os eventos de AS estão inseridos: 


\begin{tabular}{|c|c|c|c|c|}
\hline Arquitetura & Ins_cluster & Del_cluster & Indel_cluster & Cath \\
\hline União Ortogonal (OrthogonalBundle -1.10) & $12(19.3 \%)$ & $\begin{array}{l}13(9.2 \%) \\
\left.p=0.02{ }^{*}\right)\end{array}$ & $\begin{array}{l}25(12.3 \%) \\
p=0.08(*)\end{array}$ & $270(16.3 \%)$ \\
\hline União para cima e para baixo (Up-down Bundle - 1.20) & $1(1.6 \%)$ & $8(5.7 \%)$ & $9(4.4 \%)$ & $106(6.4 \%)$ \\
\hline Barril de Beta (Beta Barrel - 2.40) & $1(1.6 \%)$ & $6(4.2 \%)$ & $7(3.4 \%)$ & $110(6.6 \%)$ \\
\hline Sanduíche (Sandwich-2.60) & $\begin{array}{l}28(45 \%) \\
p=3 e-7\left(^{*}\right)\end{array}$ & $\begin{array}{l}41(29.2 \%) \\
p=0.0005(*)\end{array}$ & $\begin{array}{l}69(34.1 \%) \\
p=3 e-8(*)\end{array}$ & $278(16.8 \%)$ \\
\hline Rolo (Roll - 3.10) & $1(1.6 \%)$ & $8(5.7 \%)$ & $9(4.4 \%)$ & $104(6.3 \%)$ \\
\hline Barril de Alpha-Beta (Alpha-Beta Barrel - 3.20) & $3(4.8 \%)$ & $\begin{array}{l}12(8.5 \%) \\
p=0.0000004(*)\end{array}$ & $15(7.4 \%)$ & $22(1.3 \%)$ \\
\hline Sanduíche de 2 camadas (2-layerSandwich -3.30) & $3(4.8 \%)$ & $\begin{array}{l}8(5.7 \%) \\
p=0.01(*)\end{array}$ & $11(5.4 \%)$ & $205(12.4 \%)$ \\
\hline Sanduíche de 3 camadas (3-layer Sandwich - 3.40) & $5(8 \%)$ & $\begin{array}{l}27(19.2 \%) \\
p=0.02(*)\end{array}$ & $32(15.8 \%)$ & $204(12.3 \%)$ \\
\hline Outros & $8(12.9 \%)$ & $17(12.1 \%)$ & $25(12.3 \%)$ & $348(21.1 \%)$ \\
\hline Total & 62 & 140 & 202 & 1647 \\
\hline
\end{tabular}


Podemos dizer que as inserções tendem a ocorrer significantemente em arquiteturas do tipo sandwich. As deleções também tendem a ocorrer significantemente nessa arquitetura, mas também em outros, como orthogonal bundle, alpha-beta barrel, 2-layer sandwich, 3-layer sandwich. Quando não fazemos distinção entre inserções e deleções, essa tendência passa a ser significante somente para orthogonal bundle e sandwich. Sabendo que orthogonal bundles são arquiteturas predominantes em proteínas relacionadas a ligação, ativação e interação com DNA/RNA, as funções das proteínas com essa arquitetura corroboram com outro resultado visto anteriomente por Yura e colaboradores em que 50\% dos genes relacionados a eventos de AS estavam envolvidos em transcrição e tradução. As regiões de AS também foram relacionadas a modificação da interação proteína-DNA/RNA, o que reforça a alteração desses domínios por inserção/deleção de trechos de AS. A outra arquitetura estatisticamente significante para os casos de AS, sandwich, engloba proteínas com diversas funções enzimáticas. Nos nossos resultados, praticamente todos os casos mapeados nessa arquitetura representam os domínios "semelhantes a imunoglobulina" (immunoglobulin-like). Proteínas que possuem esse domínio são conhecidas por estarem altamente relacionadas aos eventos de AS e um exemplo disso pode ser visto pela quantidade de artigos disponíveis relacionando immunoglobulin-like a AS (75 artigos no PubMed). Além disso, a maioria das modificações causadas por AS em proteínas com essa arquitetura leva ao desenvolvimento de doenças, especialmente tumores, devido ao papel fundamental que esses domínios exercem no sistema imune e no desenvolvimento.

Outras características foram verificadas para os eventos de AS, como a relação entre os tamanhos desses eventos e os tamanhos dos domínios estruturais em que eles estão inseridos e a distribuição da quantidade de eventos de AS para domínios de diferentes tamanhos. Em ambas análises não foram verificadas diferenças estatitsticamente 
significantes entre as regiões de AS e outros trechos de proteínas de mesmo tamanho escolhidas randomicamente. Podemos dizer que existem algumas tendências a determinadas classes de proteínas quando analisamos os casos de inserção/deleção mapeados em domínios. Entretanto, essa tendência não é vista quando unimos os casos de inserção/deleção. Se considerarmos que não existem mecanismos para modificações estruturais específicos de inserções ou deleções, podemos dizer que não há uma tendência a determinadas classes de domínios. Porém, isso não ocorre para arquiteturas, onde verificamos que orthogonal bundle e immunoglobulin-like estão mais associados a eventos de AS do que o esperado, indicando as modificações funcionais que podem ser causadas por ese tipo de evento. 


\subsection{Eventos de splicing alternativo estão relacionados a amino ácidos funcionais?}

Podemos dizer que características biofísicas importantes de resíduos de proteínas são sua acessibilidade ao solvente e flexibilidade. Essas características permitem a identificação daqueles resíduos que mais interagem com água e, consequentemente, fazem menos interações com a região central da proteína. Com isso, aqueles que estão expostos terão uma maior flexibilidade devido a grande quantidade de interações com o solvente. Portanto, quando verificamos que resíduos expostos ao solvente não se encontram flexíveis e, sim, rígidos, podemos considerar que eles podem exercer um papel importante na proteína, tanto na interação com outras proteínas quanto na interação com ligantes [Schlessinger (2005)].

Um programa para medir a acessibilidade ao solvente e flexibilidade desses aminoácidos foi realizado por Avner Schlessinger, o ProfBval [Schlessinger (2006)]. Como esse programa só permite analisar uma proteína por vez através de sua página na rede, o autor gentilmente rodou localmente o programa para o conjunto de proteínas relacionadas a eventos de AS. Os resultados podem ser verificados a seguir: 


\begin{tabular}{|c|c|c|c|c|}
\hline & $\begin{array}{c}\text { Exposto \& } \\
\text { Rígido } \\
\end{array}$ & $\begin{array}{c}\text { Exposto \& } \\
\text { Flexivel } \\
\end{array}$ & $\begin{array}{c}\text { Interno \& } \\
\text { Rígido }\end{array}$ & $\begin{array}{c}\text { Interno \& } \\
\text { Flexivel }\end{array}$ \\
\hline \multirow[t]{2}{*}{ Indel_cluster } & $\begin{array}{c}19,9 \% \\
(100 / 501)\end{array}$ & $\begin{array}{c}46,3 \% \\
(232 / 501)\end{array}$ & $\begin{array}{c}25,7 \% \\
(129 / 501)\end{array}$ & $\begin{array}{c}7,9 \% \\
(40 / 501)\end{array}$ \\
\hline & $\begin{array}{c}\chi^{2}=34,6 \\
(\mathrm{p}<0.0001)\end{array}$ & & $\begin{array}{c}\chi^{2}=11,9 \\
(p=0.0005)\end{array}$ & $\begin{array}{c}\chi^{2}=16,4 \\
(\mathrm{p}<0.0001)\end{array}$ \\
\hline \multirow[t]{2}{*}{ Del_cluster } & $\begin{array}{c}16,5 \% \\
(59 / 356)\end{array}$ & $\begin{array}{c}48,5 \% \\
(173 / 356)\end{array}$ & $\begin{array}{c}27,2 \% \\
(97 / 356)\end{array}$ & $\begin{array}{c}7,5 \% \\
(27 / 356)\end{array}$ \\
\hline & $\begin{array}{c}\chi^{2}=9,4 \\
(p=0.002)\end{array}$ & & $\begin{array}{c}\chi^{2}=5,4 \\
(p=0.01)\end{array}$ & $\begin{array}{c}\chi^{2}=3,8 \\
(p=0.05)\end{array}$ \\
\hline \multirow[t]{2}{*}{ Ins_cluster } & $\begin{array}{c}28,3 \% \\
(41 / 145)\end{array}$ & $\begin{array}{c}40,7 \% \\
(59 / 145)\end{array}$ & $\begin{array}{c}22,1 \% \\
(32 / 145)\end{array}$ & $\begin{array}{c}9 \% \\
(13 / 145)\end{array}$ \\
\hline & $\begin{array}{c}\chi^{2}=40,3 \\
(\mathrm{p}<0.0001)\end{array}$ & & $\begin{array}{c}\chi^{2}=7,9 \\
(\mathrm{p}=0.004)\end{array}$ & $\begin{array}{c}\chi^{2}=38,0 \\
(\mathrm{p}<0.0001)\end{array}$ \\
\hline $\begin{array}{c}\text { Sorteio } \\
(\mathbf{1 0 . 0 0 0 )}\end{array}$ & $\begin{array}{c}11.3 \% \\
(1130 / 10000)\end{array}$ & $\begin{array}{c}44.6 \% \\
(4467 / 10000)\end{array}$ & $\begin{array}{c}33.1 \% \\
(3319 / 10000)\end{array}$ & $\begin{array}{c}10.8 \% \\
(1085 / 10000)\end{array}$ \\
\hline
\end{tabular}

Tabela 4.5.1 - Frequência dos aminoácidos agrupados (cluster_pdb_90\%) das bordas de inserções, deleções e indels com diferentes características biofísicas (exposição e flexibilidade) dados pelo programa ProfBval. 
Os nosso resultados indicam que, para amino ácidos nas bordas de inserções, deleções e indels há um aumento na quantidade de resíduos “expostos e rígidos”. Também verificamos uma diminuição na quantidade de resíduos "internos e rígidos" e "internos e flexíveis". Isso indica uma diminuição na quantidade de resíduos das bordas de AS dentro das proteínas (internos) e, consequentemente, uma aumento na quantidade de resíduos expostos. Entretanto, devemos destacar que o aumento nos resíduos expostos não ocorre em resíduos flexíveis, ou seja, que interagem somente com o solvente mas, sim, em resíduos rígidos, que provavelmente estão fazendo interações com ligantes ou com outras proteínas.

A exposição de resíduos foi previamente tratada em outros trabalhos. No trabalho de Wang e colaboradores, foi visto que a maioria dos aminoácidos relacionados a AS (75\%) encontram-se expostos a superfície, sugerindo que, alterando esses resíduos expostos, os eventos de AS poderiam não alterar significantemente o enovelamento das proteínas. Entretanto, resíduos expostos a superfície podem simplesmente estar interagindo com a água e, não necessariamente, terem um papel de interação na proteína. Nesse sentido, o programa que utilizamos para a predição dos resíduos funcionais, Profbval, considera os valores experimentais das estruturas cristalográficas, como B-factor, para medir a flexibilidade, confirmando a funcionalidade desses aminoácidos na estrutura protéica.

Em outro trabalho, Yura e colaboradores [Yura (2006)] mapeia as localizações das regiões de AS (não somente das bordas) para verificar se esses trechos estão no interior ou na superfície das proteínas. Seus resultados indicam que cerca de $65 \%$ dos resíduos de regiões de AS encontram-se no interior das estruturas. Esse resultado discorda do resultado do trabalho de Wang [Wang (2005)], em que somente $25 \%$ das regiões relacionadas a AS encontravam-se, pelo menos parcialmente, no interior das proteínas. 
Nos nossos resultados, verificamos a quantidade de proteínas agrupadas que possuem pelo menos 3 resíduos dentro da estrutura protéica (deleção) a fim de encontrar regiões de AS pelo menos parcialmente inseridas na estrutura. Como resultado, encontramos $79.5 \%$ das regiões de AS (305/385) estando, pelo menos parcialmente, inseridas na estrutura protéica. Quando corremos uma janela de mesmo tamanho do trecho de AS ao longo das proteínas e contamos a quantidade de janelas que possuem pelo menos 3 resíduos internos, encontramos 55,2\% dos trechos (35.596/64.519) inseridos na estrutura protéica.

Portanto, nossos resultados indicam que os resíduos ao longo dos trechos de AS possuem características biofísicas diferentes dos resíduos das bordas de AS. Enquanto os resíduos da borda estão mais expostos e menos flexíveis do que o esperado, indicando um papel funcional na estrutura, o trecho de AS não apresenta esse comportamento. Esses trechos estão mais inseridos na estrutura do que outras regiões ao longo da mesma proteína. Isso corrobora com outros resultados [Wang (2005) e Yura (2006)] e indica que os amino ácidos da região de AS estão mais inseridos na estrutra protéica do que o esperado. 


\subsection{Quão próximo o evento de AS está dos sítios de ligacão da proteína?}

Como vimos na análise anterior, os trechos de AS possuem uma maior quantidade de aminoácidos inseridos na estrutura do que o esperado e as bordas desses trechos possuem características funcionais, podendo estar associadas a interações com ligantes (íons, substratos e fármacos também chamados aqui de hetero-átomos) ou com outras proteínas. Como temos acesso a uma quantidade razoável de estruturas protéicas complexadas com ligantes no PDB (cerca de 200), decidimos verificar se os trechos de AS tendem a estar mais próximos dos sítios de ligação nas estruturas protéicas. A verificação da interação proteína-proteína não foi possível utilizando os dados das proteínas do PDB devido a pequena quantidade de estruturas complexadas disponíveis.

Iniciando nossas análises sobre os sítios de ligação, decidimos investigar quais as distâncias de interação proteína-ligante são mais comuns para os trechos de AS e para outras regiões da proteína com o mesmo tamanho que a região de AS. Os gráficos a seguir reportam a frequência de diferentes distâncias proteína-ligante para os trechos de AS e para todos os outros trechos da proteína: 

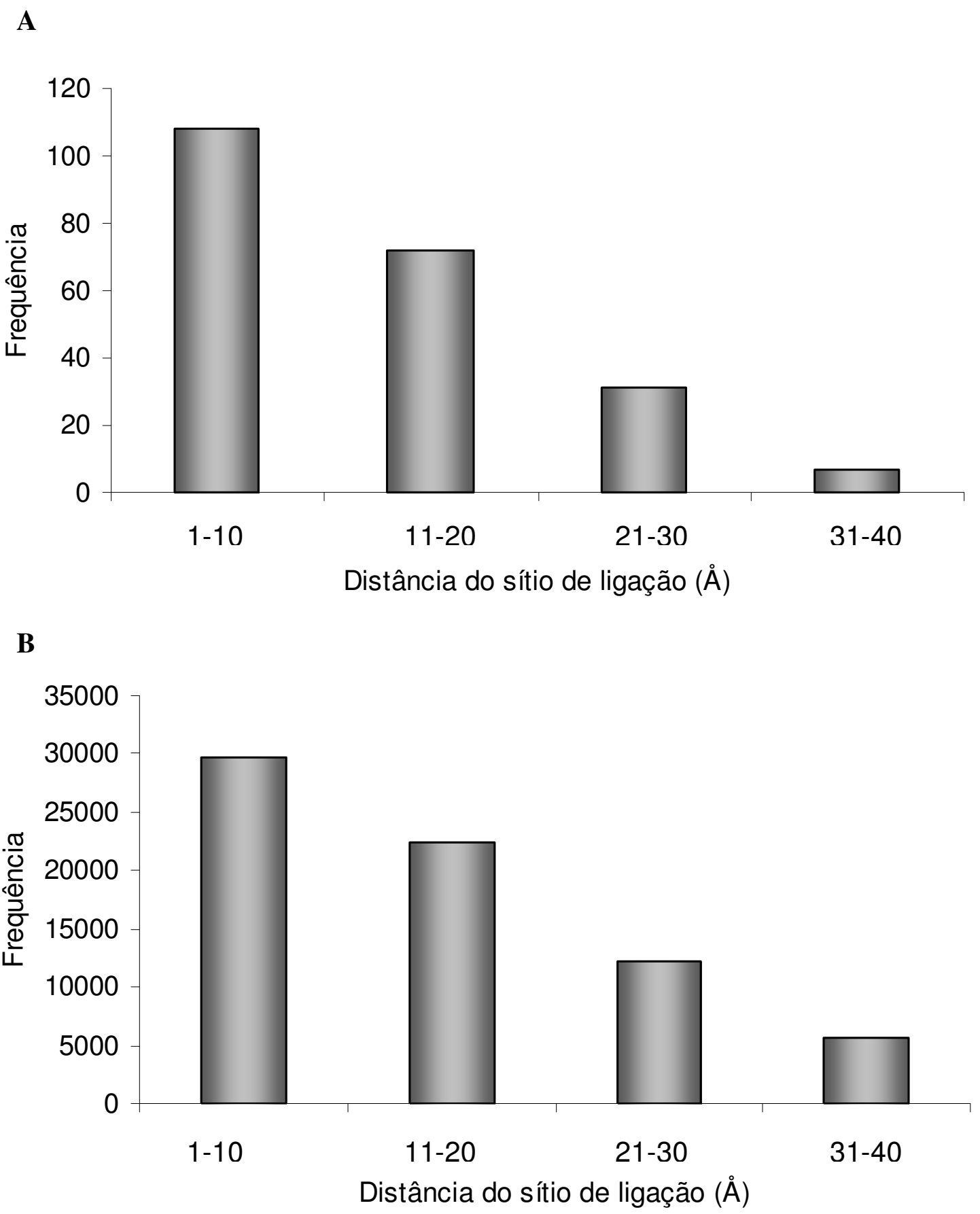

Figura 4.6.1. Frequência das menores distâncias proteína-ligante para: A. o trecho de AS; B. toda a proteína. 
Em ambos os gráficos podemos verificar que as distâncias proteína-ligante mais frequentes tanto para os trechos de AS quanto para as janelas correndo o resto da proteína ocorrem entre 1-10 A e vai diminuindo para outras distâncias.

Apesar das distribuições de frequência das distâncias proteína-ligante encontradas entre trechos de AS e entre outros trechos da proteína, não podemos dizer que os trechos de AS encontram-se mais próximos ou mais distantes do sítios de ligação do que o esperado. Para verificar essa tendência calculamos a distância proteína-ligante entre o trecho de AS e o sítio de ligação da proteína, sendo que moléculas de água foram excluídas dessa análise. Após calcular a distância de todos os átomos do ligante em relação a todos os resíduos da região de AS, verificamos qual é o resíduo mais próximo. Para saber se essa "proximidade" poderia ser verificada ao acaso para outros resíduos na proteína, corremos uma janela do tamanho da região de AS ao longo de toda a proteína e verificamos qual o aminoácido mais próximo em cada janela. Por fim, comparamos a distância do amino ácido mais próximo da região de AS com a distância de cada aminoácido mais próximo em cada janela. O percentil é calculado, considerando quantos amino ácidos do resto da proteína estão mais próximos que o aminoácido da região de AS. Quanto menor o percentil, mais difícil é encontrar amino ácidos tão próximos do ligante quanto o resíduo da região de AS. Portanto, quanto maior, mais fácil é encontrar amino ácidos tão próximos do ligante quanto o resto da proteína. Esse resultado pode ser visto na figura a seguir: 


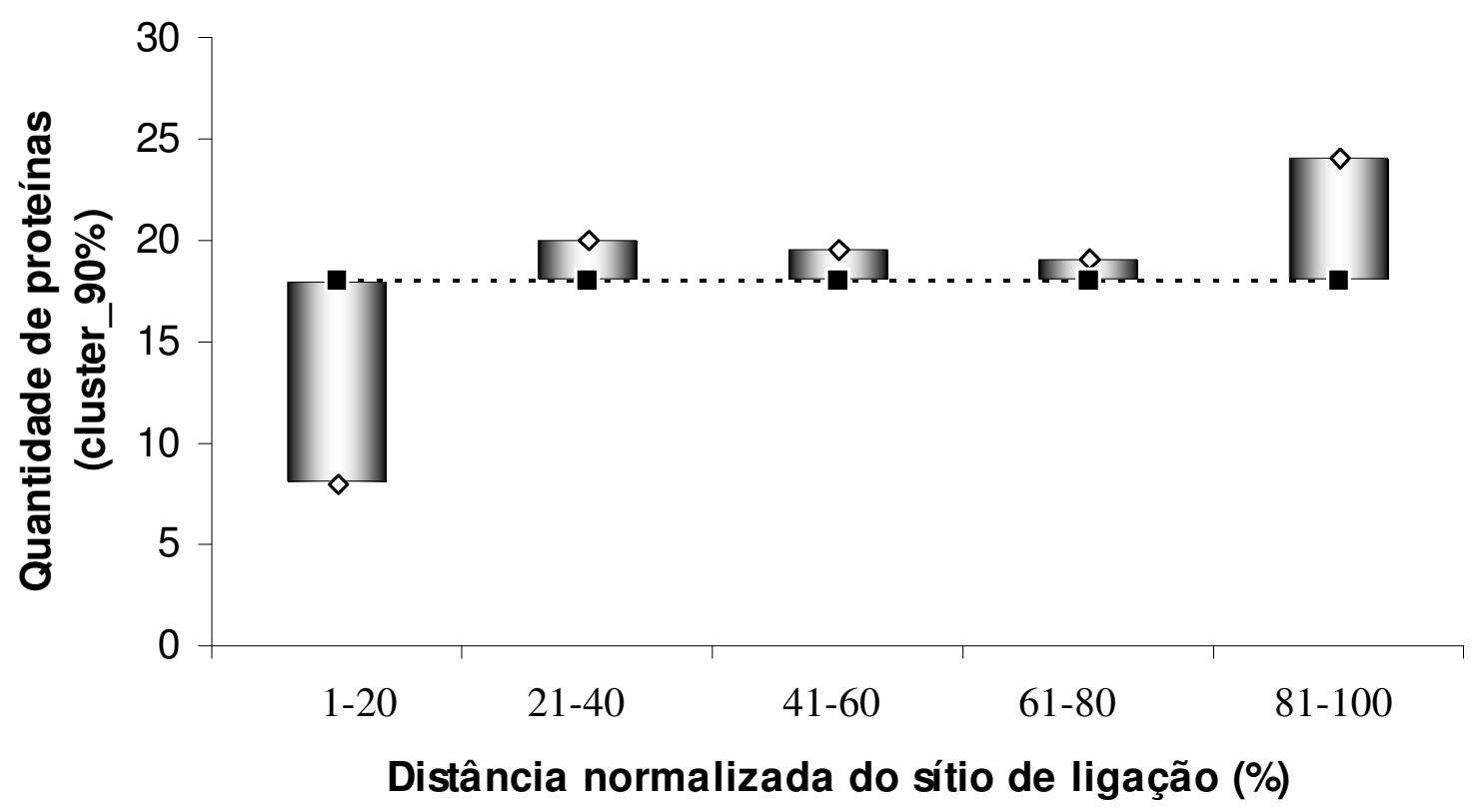

Figura 4.6.2. Gráfico da quantidade de proteínas agrupadas (cluster_pdb_90\%) de acordo com a distância normalizada do sítio de ligação. As barras cinzas demonstram a diferença de cada distância em relação a média (quadrados em preto).

Como pode ser visto, existem poucos casos em que o percentil é pequeno $(0-0.2)$ e muitos casos em que o percentil é grande (entre 0.8 - 1). Isso nos leva a interpretação de que temos poucos casos em que as distâncias ligante-proteína encontradas na proteína são menores do que a distância do trecho de AS. Paralelamente, temos muitos casos em que essa distância é maior para os trechos de AS do que a distância ligante-proteína dos resíduos ao longo da proteína. Portanto, em muitos casos é comum encontrar amino ácidos tão próximos ao ligante, indicando que a escolha de regiões de AS não deve estar relacionada a modificação de trechos próximos aos sítios de ligação. 
Verificando quais são as distâncias encontradas nas regiões em que o percentil é menor (até 0.2), podem ser vistas distâncias que vão de 14 a 58 Å. Então podemos considerar que os poucos casos em que a distância do trecho de AS é menor que a distância do resto da proteína são compostos por distâncias de 14-58 $\AA$, que podemos considerar grandes quando estamos tratando de interação proteína-ligante. Verificando as distâncias encontradas para percentis maiores $(0.8$ - 1), foi possível notar que todos os casos possuem $6 \AA$ de distância proteína-ligante. Depurando as frequências de distâncias entre 1-10 A, há um crescimento na frequência de distâncias até $6 \AA$ e, a partir dessa distância, as frequências diminuem gradualmente. Isso indica que nas distribuições proteína-ligante descritas no PDB, existe um máximo em $6 \AA$, sendo que as distâncias proteína-ligante menores que $6 \AA$ são menos frequentes, assim como as distâncias maiores que esse valor. Portanto, podemos dizer que ter muitos casos em que a distância do trecho de AS é maior do que a distância do resto da proteína para esse valor (6 $\AA$ ) não é muito significativo, uma vez que as frequências de todas as outras distâncias, maiores ou menores que esse valor, serão normalmente menos frequentes.

Resumindo nossas análises, devemos destacar que utilizamos os resíduos da proteína relacionada a AS para determinar quão próximo estão os sítios de ligação das regiões de AS. Através dessa comparação podemos verificar que distâncias menores são as mais comuns para interação proteína-ligante. Além disso, as regiões relacionadas a AS não se encontram mais próximas dos sítios de ligação que outros resíduos ao longo da proteína. Entretanto, não podemos dizer que eles se encontram mais longe desses sítos do que o esperado. 
Revendo a literatura, não há um consenso se o evento de splicing alternativo (AS) modificará os sítos de ligação de proteínas. Offman e colaboradores [Offman (2004)] utilizaram 42 isoformas com informação experimental para realizar suas análises e não encontraram relevância estatística significante na correlação entre as regiões de AS e sítios funcionais de proteínas, especificamente aqueles sítios de interação proteína-proteína, não sendo medidos outros tipos de interação. Como esse resultado poderia estar sendo prejudicado pela quantidade de dados, Yura [Yura (2006)] aumentou a quantidade de isoformas para 429 e verificou que as regiões de AS possuem relevância funcional para as estruturas tridimensionais de proteínas. Apesar dessa afirmação, concluída relacionando os dados de estabilidade e função das estruturas protéicas, somente 23\% (57/242) dos sítios de ligação proteína-ligante descritos por ele incluem regiões de AS. 


\subsection{Bordas de regiões de splicing alternativo estão espacialmente mais próximas na estrutura protéica?}

Considerando que as bordas de regiões de AS podem estar espacialmente distantes ou próximas, supomos que, se retirarmos a sequência entre resíduos espacialmente distantes, poderá haver uma modificação muito maior na estrutura do que se esses resíduos estivessem espacialmente próximos. Sabendo que a quantidade de resíduos retirados de uma sequência primária não corresponde a distância espacial entre esses resíduos em uma estrutura protéica enovelada, realizamos a medição da distância espacial entre os resíduos flanqueadores da região de deleção causada por AS nas estruturas protéicas disponíveis no PDB. A distância euclideana entre esses resíduos foi calculada como descrito a seguir:

$$
\mathrm{D}=\sqrt{\left(\mathrm{x}_{1}-\mathrm{x}_{2}\right) 2+\left(\mathrm{y}_{1}-\mathrm{y}_{2}\right) 2+\left(\mathrm{z}_{1}-\mathrm{z}_{2}\right)^{2}}
$$

em que $\mathrm{x} 1$, y1 e z1 descrevem as coordenadas do C $\alpha$ do resíduo flanqueador incial (borda

1) e $\mathrm{x} 2$, y2 e z2 descrevem as coordenadas do Ca do resíduos flanqueador final (borda 2) e D é a distância euclideana entre eles, como pode ser exemplificado na figura a seguir: 


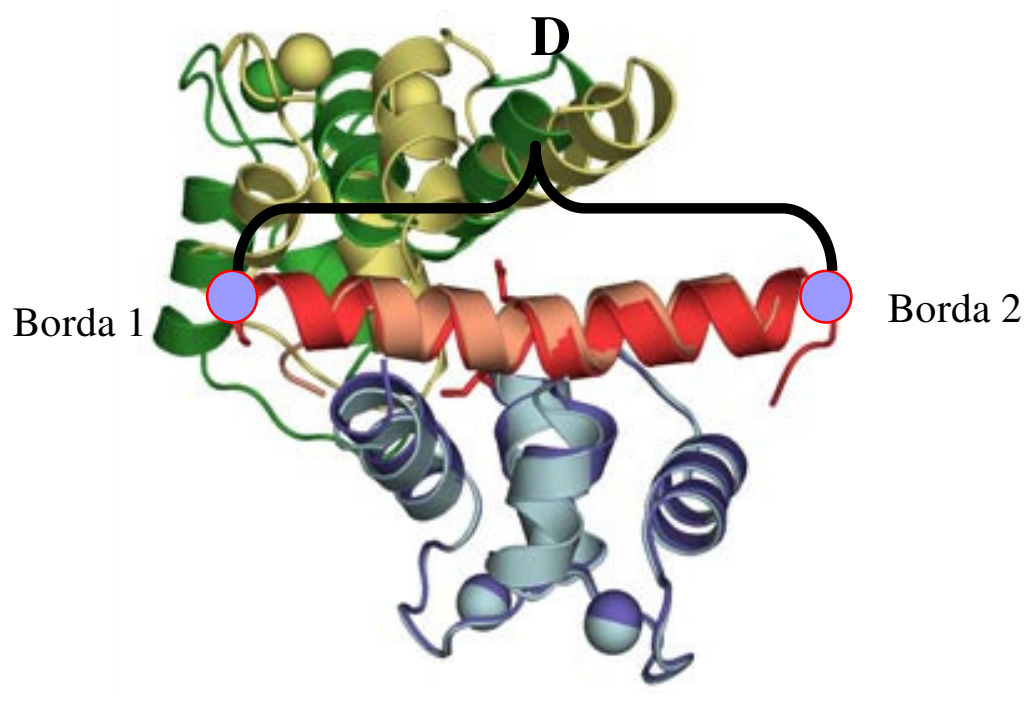

Figura 4.7.1. - Ilustração da distância espacial das bordas (região flanqueadora) representadas por círculos nas regiões de deleção em estruturas protéicas.

No gráfico a seguir, temos a frequência das distâncias espaciais no nosso dado de AS: 


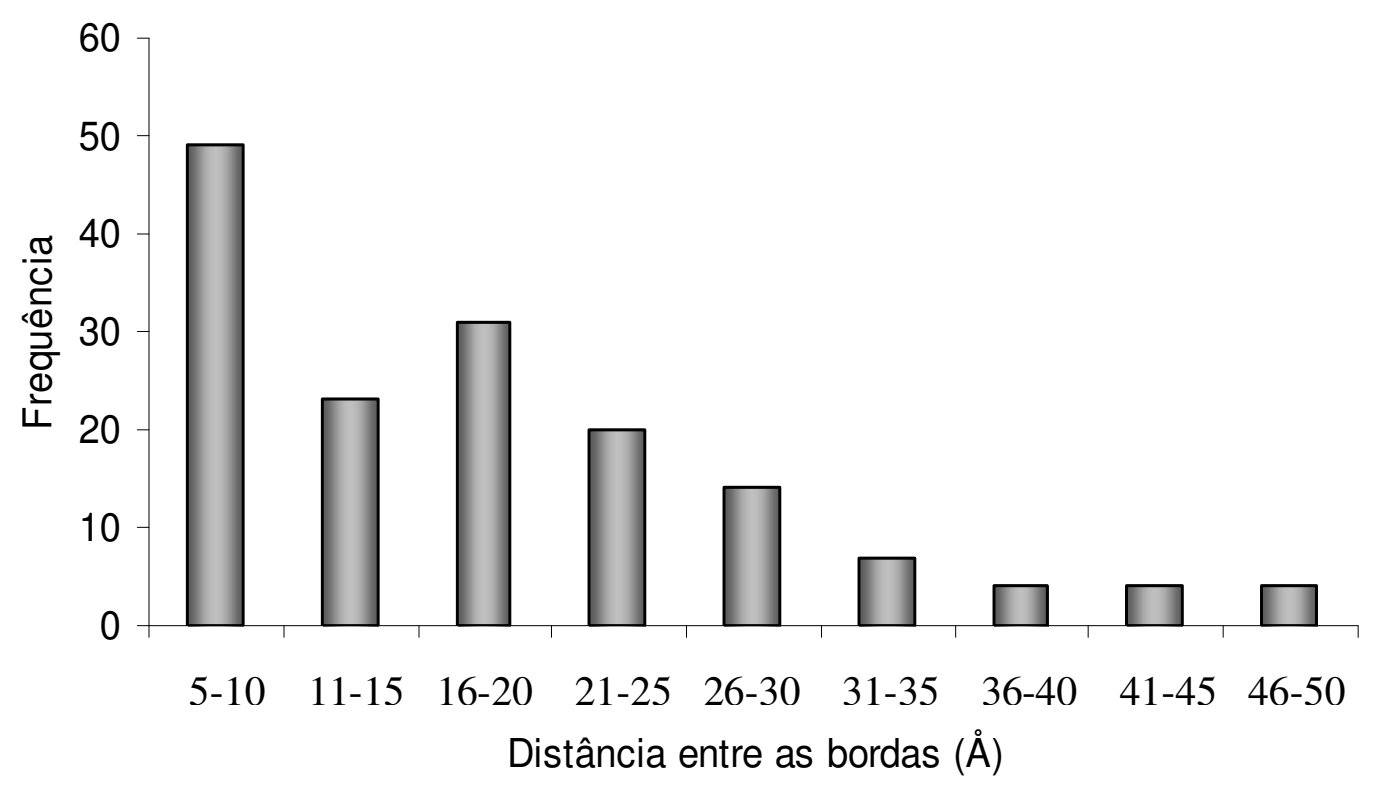

Figura 4.7.2. - Frequência da distância espacial das bordas (região flanqueadora) nas regiões de deleção em estruturas protéicas.

Na figura 4.7.2 podemos verificar que quanto menor as distâncias espaciais entre as bordas dos trechos de AS, mais frequentemente eles ocorrem. Isso poderia sugerir que pequenas distâncias entre as bordas são preferenciais para os trechos de AS. Entretanto, essa afirmação só pode ser feita se compararmos esse dado ao comumente encontrado em regiões da proteína com os mesmos tamanhos de resíduos (distâncias sequenciais).

Portanto, a medição das distâncias entre as bordas de AS foi realizada não somente para a região de AS, como também para toda a proteína, sendo que uma janela de tamanho equivalente ao tamanho das regiões de AS percorrem a proteína, movendo-se a cada resíduo $(i+1)$.

Tendo as distâncias espaciais das regiões de AS e as distâncias espaciais de trechos de mesmo tamanho ao longo da proteína, fizemos uma comparação entre esses dados. 
Calculamos a média e o desvio padrão das distâncias espaciais da proteína e comparamos com a média das regiões de splicing alternativo para intervalos de distância sequencial (de 10 em 10 amino ácidos), como pode ser visto na figura a seguir:

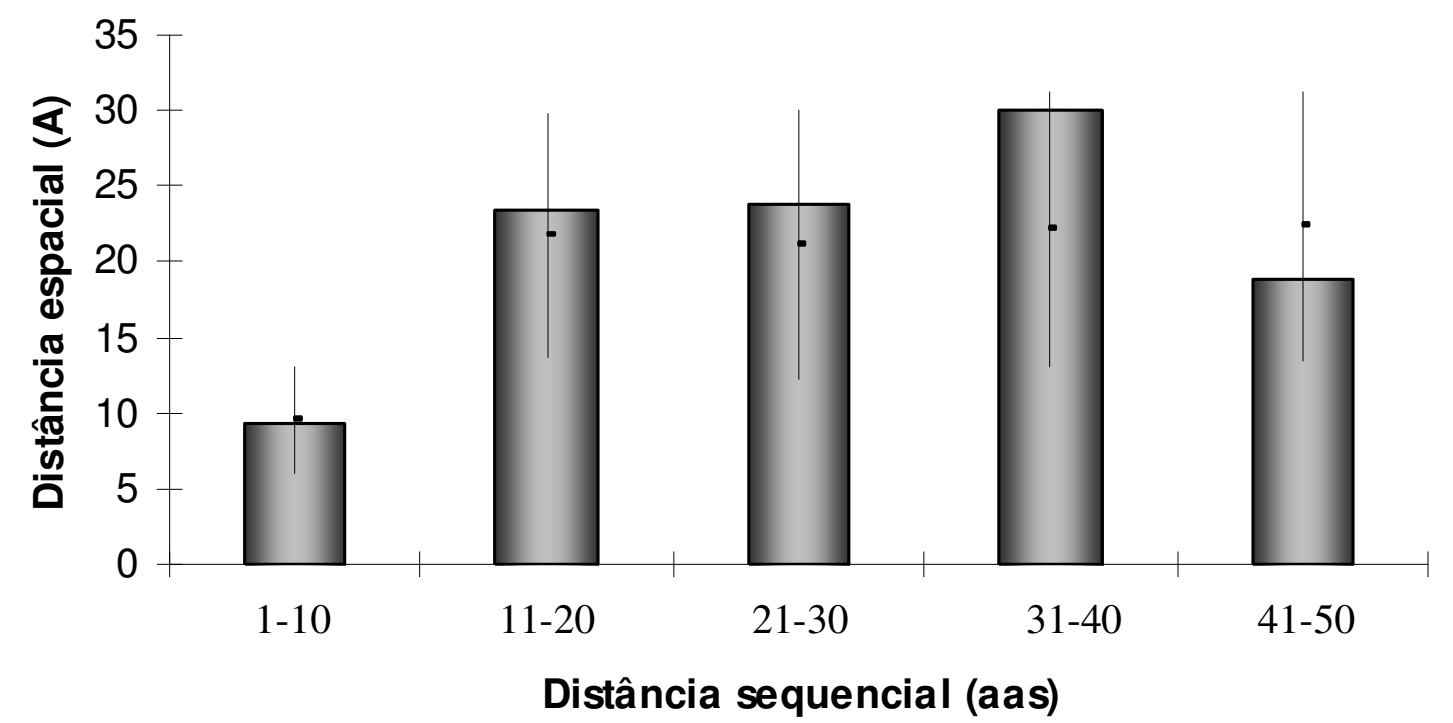

Figura 4.7.3. Gráfico da distribuição das distâncias espaciais de acordo com o tamanho da região spliceada (distância sequencial). Barras cinzas representam as distâncias dos dados de AS. Pontos e linhas em preto mostram, respectivamente, as médias e suas variações (um desvio padrão) da mesma distância sequencial no resto da proteína.

De acordo com esse gráfico, as médias dos tamanhos das regiões de splicing alternativo estão completamente dentro dos desvios padrões calculados a partir das distâncias espaciais com a mesma distância sequencial ao longo da proteína.

$\mathrm{O}$ resultado anterior sugeria que trechos de AS tinham tendência a ocorrer mais frequentemente em pequenas distâncias. Porém, esse segundo resultado nos mostra que essa distribuição não é significativa comparada ao resto da proteína uma vez que, em outras 
regiões da proteína com as mesmas distâncias sequenciais, podemos encontradas distâncias espaciais equivalentes. Com isso, podemos dizer que as regiões de AS não possuem restrições espaciais para que suas bordas se encontrem mais próximas do que qualquer outra região da proteína, o que pode indicar que a retirada de trechos de AS da estrutura protéica poderá trazer grandes modificações as isoformas. 


\subsection{A região de splicing alternativo faz mais interacões inter - residuais do que outras regiões da proteína?}

Nessa análise, verificamos se as regiões relacionadas ao AS estariam realizando mais ou menos interações entre resíduos da mesma proteína do que outras regiões de mesmo tamanho ao longo da proteína. Fragmentos de proteínas, também conhecidos como esquemas (schemas), podem ser recombinados sem tirar a integridade da estrutura tridimensional [Voigt (2002)]. Calculando as interações inter-residuais de uma proteína, podemos determinar quantas dessas interações são rompidas quando é formada uma isoforma de $\mathrm{AS}$. Se as regiões de AS realizam menos interações que outras regiões da proteína, sua retirada poderá trazer menos modificações nas estruturas das proteínas. Pelo contrário, se essas regiões fazem mais interações, podemos dizer que elas são componentes estruturais importantes no enovelamento das proteínas modificadas por AS.

Para fazer esse cálculo, foi realizado um programa em que uma esfera com $4.5 \AA$ de raio percorre a região deletada pelo evento de AS contando o número de aminoácidos dentro da mesma. Dessa forma, tem-se o total de aminoácidos interagindo nessa região. Essa distância inclui interações covalentes, eletrostáticas, hidrofóbicas e van der Waals. Pontes de hidrogênio não foram medidas, uma vez que nem todas proteínas possuem a descrição explícita dos hidrogênios, o que poderia trazer diferenças para os resultados entre as proteínas.

Para calcular a quantidade de interações inter-residuais ao longo da proteína, uma janela do tamanho da região de AS percorre toda a proteína, movendo-se a cada resíduo (i+1). Somando a quantidade de interações em cada janela, calculamos a quantidade de 
interações de regiões de AS de diferentes tamanhos e determinamos a quantidade de regiões da proteína que possuem um número maior de interações do que a região de AS.

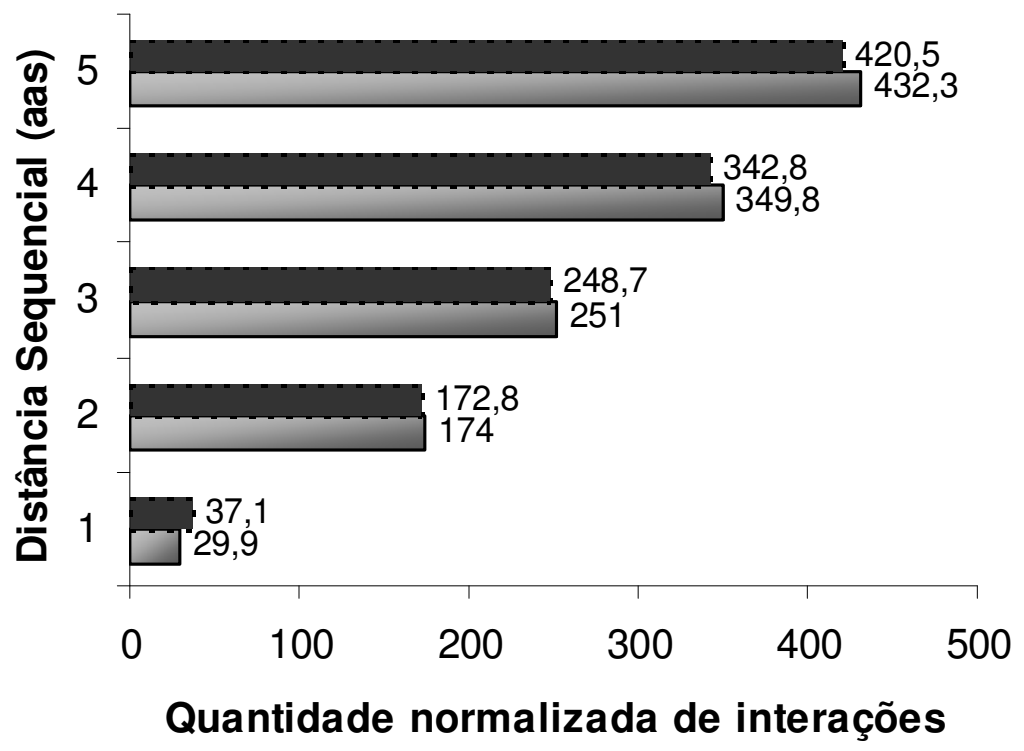

Figura 4.8.1 - Distribuição da quantidade normalizada de interações inter-residuais de acordo com a distância sequencial. Barras em preto, a quantidade média de interações do PDB e barras cinzas a quantidade média de interações no trecho deletado de splicing alternativo. 


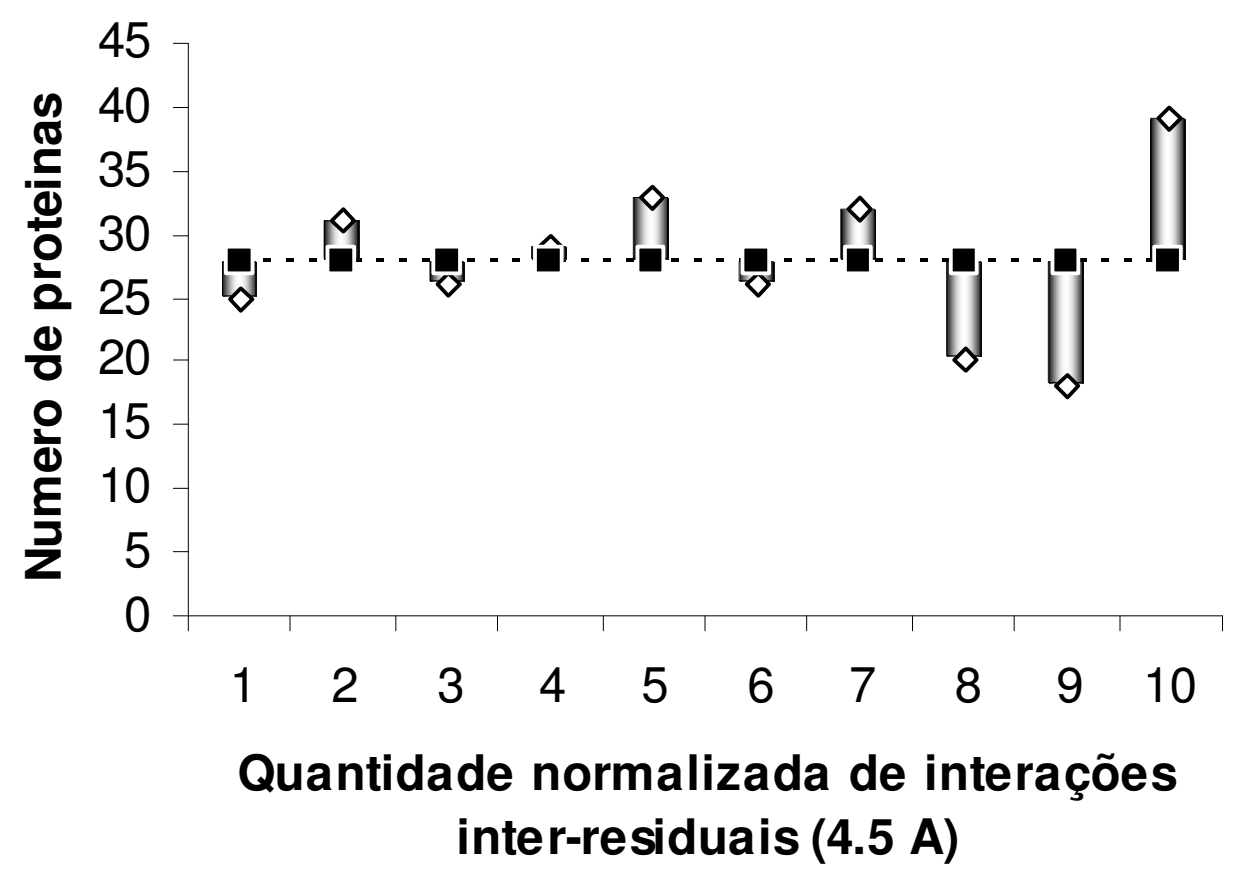

Figura 4.8.2 - Gráfico da quantidade de proteínas agrupadas (cluster_90\%) de acordo com a distribuição normalizada da quantidade de interações inter-residuais. As barras cinzas demonstram a diferença de cada distância em relação a média (quadrados em preto).

Como dito anteriormente, a quantidade de interações inter-residuais de uma região podem dar uma indicação da importância estrutural dessa região na proteína. Esse tipo de análise foi previamente realizada por Voigt [Voigt (2002)] para encontrar regiões ou blocos de proteínas preferenciais para recombinação. Analisando a quantidade de interações interresiduais do trecho de AS e sua distribuição comparada ao resto da proteína, podemos perceber que não existe nenhuma tendência específica para a quantidade de interações inter-residuais e que a quantidade em trechos de mesmo tamanho é muito semelhante, indicando que as regiões de AS não fazem mais interações inter-residuais que o resto da proteína. Uma vez que não existe minimização na quantidade de interações rompidas nas 
regiões de AS, isso indica que essas regiões não conservam informação estrutural e que as isoformas de AS podem não ser funcionais. 


\section{Conclusões e Discussão}


A fim de reunir as conclusões dessa tese, fizemos um pequeno resumo dos resultados obtidos durante a realização da mesma. Inicialmente podemos dizer que, de uma forma geral, a frequência dos dados de eventos de AS aumentam de acordo com o tamanho da sequência até 50 amino ácidos, que é um valor próximo ao tamanho médio de um exon (cerca de 120 nucleotídeos = 40 amino ácidos). Após esse valor, a frequência de AS diminui e podemos dizer que o evento de AS fica mais raro a medida que o tamanho da sequência aumenta. Os eventos de AS possui distribuições de frequência diferentes, que são condizentese com as características de cada evento (AU, ES e IR). Entretanto, essa distribuição não pode ser visualizada nos dados de AS relacionados a proteínas, devido a pouca quantidade desses casos.

Nossa verificação inicial sobre os dados do PDB e os dados de AS indicou que ambos os dados possuem redundância, o que poderia dificultar determinadas análises estatísticas sobre a relação entre AS e estruturas protéicas. A fim de resolver esse problema, descobrimos que o agrupamento (clusterização) utilizando os indexadores do Unigene ou utilizando indexadores do PDB são eficientes. Nesse trabalho, utilizamos o agrupamento das proteínas com estrutura do PDB, pois esse nos permite escolher a porcentagem de similaridade entre as sequências agrupadas. No nosso caso, a porcentagem escolhida foi a mais alta possível (90\%), permitindo que mais proteínas pudessem ser associadas aos eventos de AS durante o alinhamento realizado pelo BLAST. Nesse alinhamento, recalculamos a identidade de forma a desconsiderar os intervalos (gaps) permitindo que essa identidade fosse calculada somente para as partes da proteína que se encontravam alinhadas com a sequência de AS. Utilizamos a identidade de $90 \%$ para que as sequências 
nucleotídicas correspondessem exatamente a determinada estrutura protéica, evitando o alinhamento de parálogos.

Após resolver os problemas técnicos de alinhamento, iniciamos nossas análises sobre as características estruturais das proteínas relacionadas a AS. As análises de estrutura secundária mostraram que há uma diferença estatisticamente significante de tipos de estrutura secundária nos aminoácidos correspondentes as bordas das deleções. Nesses, há um aumento significante de estruturas em coil e uma diminuição siginificante de estruturas em hélice. Estruturas em folha não demonstraram diferenças entre aminoácidos das bordas e outros aminoácidos. Esse resultado implica que há uma preferência dos aminoácidos das bordas de deleções por regiões desestruturadas, que se reflete nos valores das bordas de indels. Essa preferência poderia significar que regiões desestruturadas são mais retiradas das isoformas de AS do que outras regiões da proteína. A hipótese de que regiões desestruturadas estariam mais associadas a eventos de AS do que o esperado, nos levou ao estudo de trabalhos publicados [Radivojac (2002), Iakoucheva (2002)] sobre a detecção de regiões desordenadas em estruturas protéicas. Regiões desordenadas são definidas como proteínas inteiras ou regiões de proteínas que não possuem uma estrutura terciária fixa, podendo estar completamente estendidas ou colapsadas. Essa definição é mais aplicada a cadeia principal do que as cadeias laterais dos resíduos de aminoácidos. Essas regiões foram demonstradas estando envolvidas em uma série de funções, onde podemos citar os sítios de interação DNA/RNA/proteína e modulação de especificidade/afinidade de regiões de ligação de proteínas. As nossas análises sobre regiões desordenadas incluía somente estruturas cristalográficas relacionadas a AS com informação completa sobre B-factor. O B-factor, uma medida do quanto o átomo oscila ou vibra em torno de uma posição específica, permite que seja calculada a mobilidade da estrutura, sendo possível selecionar 
regiões mais móveis, que podem ser consideradas regiões desordenadas. Enquanto estava sendo feita a estatística sobre a distribuição desse fator ao longo das proteínas e essa distribuição era comparada aos dados de AS, foi publicado um trabalho em que foi demonstrada a associação entre as regiões de AS e regiões desordenadas [Romero (2006)]. Embora eles tenham usado outra metodologia, construindo um banco de dados de regiões desordenadas e comparando aos dados de AS disponíveis no SWISS-PROT, seus resultados demonstraram uma forte associação entre as regiões de AS e regiões desordenadas.

Portanto, comparamos nossos dados de bordas com os dados de regiões de estruturas secundárias nos trechos de AS. Quando consideramos todos os tipos de estrutura secundária presentes nas regiões retiradas, verificamos que somente $20 \%$ dessas regiões são completamente formadas por estruturas coil, o que indica que, apesar das bordas estarem desestruturadas, as regiões retiradas são compostas também por estruturas definidas (hélice/folha). Quando medimos a quantidade de estruturas secundárias diferentes nesses trechos, verificamos que duas a três estruturas secundárias ordenadas estão nas regiões deletadas de AS.

Os resultados referentes a associação de eventos de AS a domínios estruturais indicam que as regiões, tanto de inserção quanto de deleção, não possuem tendências para nenhuma das classes de proteínas, mas possuem tendências para determinadas arquiteturas. As arquiteturas, como definidas anteriormente, são uma subdivisão das classes e irão descrever a orientação das estruturas secundárias de uma proteína considerando também as regiões de volta. 
Quanto a localização espacial das regiões retiradas durante o evento de AS, o fato dessas regiões estarem mais inseridas na estrutura do que o esperado, poderia implicar que sua retirada traria grandes mudanças na estrutura protéica de sua isoforma protéica.

Outras medidas que poderiam indicar o quanto essa estrutura seria modificada e/ou o quanto de informação estrutural as isoformas de AS possuem, não demonstraram nenhuma diferença significante entre as regiões de AS e outras regiões das estruturas protéicas. A distância entre as regiões de AS e os sítios de ligação proteína-ligante, demonstraram que essas regiões não estão mais próximas das regiões de interação proteínaligante que outras regiões da proteína. Isso não significa que a inserção/deleção de trechos de AS não irá modificar a interação proteína-ligante, somente que essa modificação ocorrerá por um "efeito dominó”,ou seja, pela modificação da interação entre aminoácidos distantes que poderá chegar a afetar a interação no sítio ativo da proteína.Apesar de estarem mais inseridos na estrutura do que o esperado, os resultados das distâncias espaciais das bordas de AS, possíveis indicadores de uma maior ou menor modificação da estrutura protéica, de acordo com o aumento ou a diminuição da distância entre as bordas, não demonstrou diferenças entre as regiões de AS e outras regiões de mesmo tamanho ao longo da proteína. Isso indica que essas bordas não possuem informação da sua localização na estrutura tridimensional protéica.

Além disso, a distribuição da quantidade de interações inter-residuais, que poderia indicar qual a extensão da modificação causada pela inserção/retirada de regiões de AS, uma vez que a presença de poucas interações inter-residuais sugerem uma retirada/inserção de um trecho da proteína com menos consequências estruturais do que outras regiões, não demonstrou nenhuma diferença entre as regiões de AS e outras regiões da proteína. 
As isoformas de AS utilizam o mesmo gene para, através da combinação de diferentes exons/íntrons (ou pedaços dos mesmos), dar origem a novas proteínas. Sabendo que o mecanismo de transmissão de informação nucleotídeo-proteína e o enovelamento dessas proteínas não estão completamente desvendados, consideramos que o estudo estrutural das isoformas protéicas poderia ajudar a elucidar como é feita a escolha dos diferentes sítios de splice no mesmo gene que originarão diferentes proteínas. Dessa forma, uma vez encontrados determinados padrões de modificações estruturais seria possível catalogar, por exemplo, aquelas modificações mais comuns em isoformas de AS. Além disso, uma vez que essas proteínas são formadas a partir do mesmo gene, poderíamos considerar que a inserção/deleção de trechos na estrutura protéica traria modificações estruturais que poderiam ser comuns a maioria das proteínas, gerando diversidade a partir da recombinação de determinados padrões de características estruturais. Porém, de acordo com nossos resultados e de outros autores, a informação estrutural vinda das isoformas de AS possuem pouquíssimos padrões estruturais.

Portanto, podemos dizer que o mapeamento das regiões de AS nas estruturas protéicas demonstrou que as bordas desses eventos possuem características biofísicas distinguíveis de outros aminoácidos na proteína. Isso foi verificado tanto pelas estruturas secundárias quanto pela localização dessas bordas na estrutura, sendo mais expostas e rígidas, o que permite associá-las a características funcionais, de interação com ligantes ou com outras proteínas. Uma justificativa para essa conservação de certas características estruturais nas bordas de AS pode ser a conservação da informação nucleotídeo-proteína devido ao reconhecimento dos sítios de splice. Esses sítios, altamente conservados nas sequências nucleotídicas devido a sua importância no reconhecimento de exons/introns, parecem também conservar informação estrutural. Podemos dizer então que essa 
conservação, apesar de não implicar uma tendência a determinados aminoácidos, é refletida nas características biofísicas desses aminoácidos das bordas nas estruturas protéicas.

Em compensação, as regiões de AS são muito sutis na preservação dessa informação nucleotídeo-proteína, o que também faz sentido se considerarmos que há poucas informações muito conservadas dentro das sequências de nucleotídeos que permitem "marcar" essas sequências como passíveis de AS. Nossos resultados indicam que esses trechos de AS possuem pouca diversidade de estruturas secundárias e estão mais inseridas na estrutura mas não se diferenciam de outras regiões da proteína quanto a proximidade dos sítios de interação proteína-ligante, quanto a distância espacial entre as bordas e quanto a quantidade de interações inter-residuais.

Esses resultados também podem ser interpretados como o evento de AS causando poucas modificações na estrutura protéica. Essa hipótese é apoiada pelas estruturas cristalográficas das isoformas de AS, em que as modificações causadas pelos eventos de AS são sutis e concentram-se principalmente na modificação da interação proteína-ligante. Porém, não podemos desconsiderar a pequena quantidade de sequências nucleotídicas descritas com eventos de AS relacionadas a estruturas protéicas (de 1-5\%), o que pode dificultar a análise das consequências desse evento nas estruturas protéicas. Além disso, devemos ressaltar que não existem métodos em larga-escala totalmente confiáveis de enovelamento de proteínas que permitam a demonstração de como são as estruturas protéicas modificadas por AS, o que nos permite somente realizar medidas sobre as estruturas de proteínas equivalentes, mas que possuem outras sequências de aminoácidos e que já se encontram enoveladas. 
6. Referências 
Altschul SF, Gish W, Miller W, Myers EW, Lipman DJ. Basic local alignment search tool. J Mol Biol. 1990 Oct 5;215(3):403-10

Anfinsen CB. Principles that govern the folding of protein chains. Science. $1973 \mathrm{Jul}$ 20;181(96):223-30.

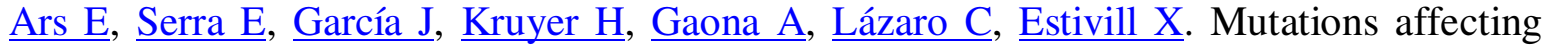
mRNA splicing are the most common molecular defects in patients with neurofibromatosis type 1 Hum Mol Genet. 2000 Jan 22;9(2):237-47

Bairoch A, Apweiler R. The SWISS-PROT protein sequence database and its supplement TrEMBL in 2000. Nucleic Acids Res. 2000 Jan 1;28(1):45-8.

Balvay L, Libri D, Fiszman MY. Pre-mRNA secondary structure and the regulation of splicing. Bioessays. 1993 Mar;15(3):165-9.

Beadle GW, Tatum ELGenetic Control of Biochemical Reactions in Neurospora. Proc Natl Acad Sci U S A. 1941 Nov 15;27(11):499-506

Berman HM, Battistuz T, Bhat TN, Bluhm WF, Bourne PE, Burkhardt K, Feng Z, Gilliland

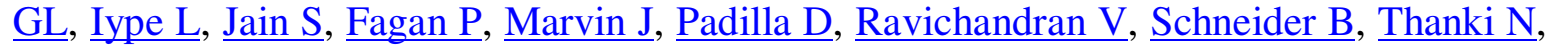
Weissig H, Westbrook JD, Zardecki C. The Protein Data Bank. Acta Crystallogr D Biol Crystallogr. 2002 Jun;58(Pt 6 No 1):899-907.

Bernstein F, Koetzle T, Williams G, Meyer EJ, Brice M, Rodgers J, Kennard O, Shimanouchi T, Tasumi M. The Protein Data Bank: a computer-based archival file for macromolecular structures. J Mol Biol 1977, 112:535-42.

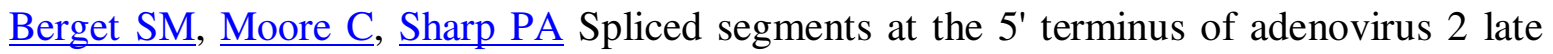
mRNA. Proc Natl Acad Sci U S A. 1977 Aug;74(8):3171-5.

Blencowe BJ. Exonic splicing enhancers: mechanism of action, diversity and role in human genetic diseases. Trends Biochem Sci. 2000 Mar;25(3):106-10

Brachet J, Chantrenne H. The function of the nucleus in the synthesis of cytoplasmatic proteins. Cold Spring Harb. Symp. Quant. Biol. 21, 329-337 (1956)

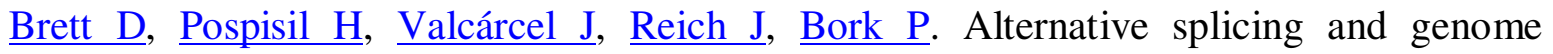
complexity. Nat Genet. 2002 Jan;30(1):29-30

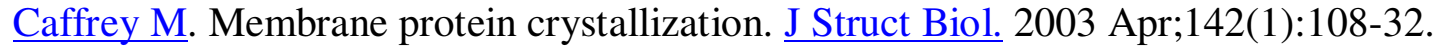

Chargaff E., Structure and function of nucleic acids as cell constituents, Fed Proc. 1951; Sep;10(3):654-9. 


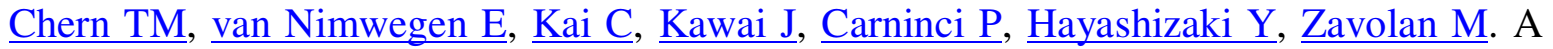
simple physical model predicts small exon length variations. PLoS Genet. 2006 Apr;2(4):e45.

Cho JH, Bandyopadhyay J, Lee J, Park CS, Ahnn J. Two isoforms of sarco/endoplasmic reticulum calcium ATPase (SERCA) are essential in Caenorhabditis elegans. Gene. 2000 Dec 31;261(2):211-9.

Chow LT, Gelinas RE, Broker TR, Roberts RJ. An amazing sequence arrangement at the 5' ends of adenovirus 2 messenger RNA Cell. 1977 Sep;12(1):1-8.

Cole KA, Krizman DB, Emmert-Buck MR. The genetics of cancer--a 3D model. Nat Genet. 1999 Jan;21(1 Suppl):38-41.

Cooper TA Highlights of alternative splicing regulation session: yes, no, maybe--a history of paradigm shifts Sci STKE. 2001 Oct 23;2001(105):PE35

Crick, F. Central Dogma of Molecular Biology. Nature 1970 Aug 8; 227:561-563

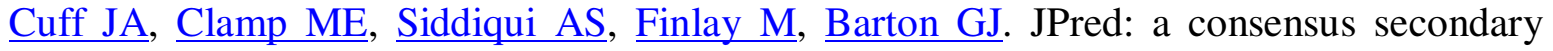
structure prediction server. Bioinformatics. 1998;14(10):892-3.

Fiegen D, Haeusler LC, Blumenstein L, Herbrand U, Dvorsky R, Vetter IR, Ahmadian MR. Alternative splicing of Rac1 generates Rac1b, a self-activating GTPase. J Biol Chem. 2004 Feb 6;279(6):4743-9.

Fleischmann RD, Adams MD, White O, Clayton RA, Kirkness EF, Kerlavage AR, Bult CJ, Tomb JF, Dougherty BA, Merrick JM, et al. Whole-genome random sequencing and assembly of Haemophilus influenzae Rd. Science. 1995 Jul 28;269(5223):496-512.

Florea L, Hartzell G, Zhang Z, Rubin GM, Miller W. A computer program for aligning a cDNA sequence with a genomic DNA sequence. Genome Res. 1998 Sep;8(9):967-74.

Frishman D, Argos P: Knowledge-based protein secondary structure assignment. Proteins 1995, 23(4):566-79

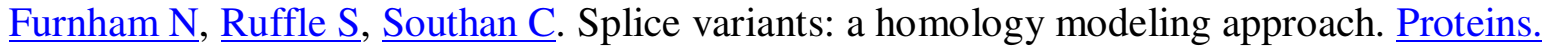
2004 Feb 15;54(3):596-608

Galante PA, Sakabe NJ, Kirschbaum-Slager N, de Souza SJ. Detection and evaluation of intron retention events in the human transcriptome. RNA. 2004 May;10(5):757-65.

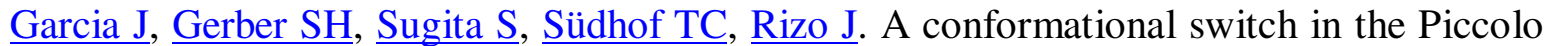
C2A domain regulated by alternative splicing. Nat Struct Mol Biol. 2004 Jan;11(1):45-53. 
Gregory SG, Barlow KF, McLay KE, Kaul R, Swarbreck D, Dunham A, Scott CE, Howe $\underline{\mathrm{KL}}$, et al. The DNA sequence and biological annotation of human chromosome 1 . Nature. 2006 May 18;441(7091):315-21

Guex N, Peitsch MC. SWISS-MODEL and the Swiss-PdbViewer: an environment for comparative protein modeling. Electrophoresis. 1997 Dec;18(15):2714-23.

Gupta S, Zink D, Korn B, Vingron M, Haas SA. Genome wide identification and classification of alternative splicing based on EST data. Bioinformatics. 2004 Nov 1;20(16):2579-85

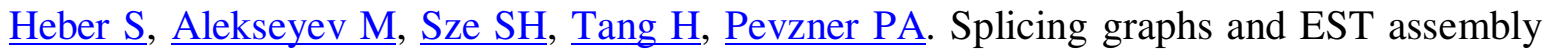
problem. Bioinformatics. 2002;18 Suppl 1:S181-8

Hentze MW, Kulozik AE. A perfect message: RNA surveillance and nonsense-mediated decay. Cell. 1999 Feb 5;96(3):307-10

$\underline{\text { Hiller M, Huse K}}$, Platzer M, Backofen R. Creation and disruption of protein features by alternative splicing -- a novel mechanism to modulate function Genome Biol. 2005;6(7):R58.

$\underline{\text { Hoos A}}$, Cordon-Cardo C. Tissue microarray profiling of cancer specimens and cell lines: opportunities and limitations Lab Invest. 2001 Oct;81(10):1331-8.

Hulo N, Bairoch A, Bulliard V, Cerutti L, De Castro E, Langendijk-Genevaux PS, Pagni $\underline{M}$, Sigrist CJ. The PROSITE database. Nucleic Acids Res. 2006 Jan 1;34(Database issue):D227-30.

Hymowitz SG, Compaan DM, Yan M, Wallweber HJ, Dixit VM, Starovasnik MA, de Vos AM. The crystal structures of EDA-A1 and EDA-A2: splice variants with distinct receptor specificity. Structure. 2003 Dec;11(12):1513-20

Iakoucheva LM, Brown CJ, Lawson JD, Obradović Z, Dunker AK. Intrinsic disorder in cell-signaling and cancer-associated proteins. J Mol Biol. 2002 Oct 25;323(3):573-84.

International Rice Genome Sequencing Project. The map-based sequence of the rice genome. Nature. 2005 Aug 11;436(7052):793-800

Jones DT. (1999) Protein secondary structure prediction based on position-specific scoring matrices. J. Mol. Biol. 292: 195-202.

Johnson JM, Castle J, Garrett-Engele P, Kan Z, Loerch PM, Armour CD, Santos R, Schadt $\underline{E E}, \underline{\text { Stoughton R}}$ Shoemaker DD. Genome-wide survey of human alternative pre-mRNA splicing with exon junction microarrays. Science. 2003 Dec 19;302(5653):2141-4

Kabsch W, Sander C: Dictionary of protein secondary structure: pattern recognition of hydrogen-bonded and geometrical features. Biopolymers 1983, 22(12):2577-2637 
Kan Z, Rouchka EC, Gish WR, States DJ. Gene structure prediction and alternative splicing analysis using genomically aligned ESTs. Genome Res. 2001 May;11(5):889-900

Kent WJ BLAT--the BLAST-like alignment tool. BLAT--the BLAST-like alignment tool. Genome Res. 2002 Apr;12(4):656-64

Kirschbaum-Slager N, Parmigiani RB, Camargo AA, de Souza SJ. Identification of human exons overexpressed in tumors through the use of genome and expressed sequence data. Physiol Genomics. 2005 May 11;21(3):423-32.

Kisielow M, Kleiner S, Nagasawa M, Faisal A, Nagamine Y. Isoform-specific knockdown and expression of adaptor protein ShcA using small interfering RNA. Biochem J. 2002 Apr 1;363(Pt 1):1-5.

Korf I, Yandell M, Bedell J. BLAST - An essential guide to the Basic Local Alignment Search Tool Sebastopol, CA: O’Reilly \& Associates, Inc. (2003)

Kriventseva EV, Koch I, Apweiler R, Vingron M, Bork P, Gelfand MS, Sunyaev S. Increase of functional diversity by alternative splicing. Trends Genet. 2003 Mar;19(3):1248 .

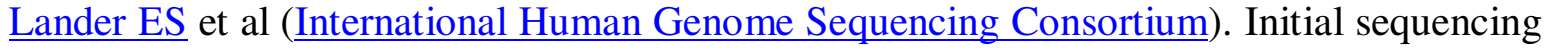
and analysis of the human genome. Nature. 2001 Feb 15;409(6822):860-921.

Lee KA, Fuda H, Lee YC, Negishi M, Strott CA, Pedersen LC. Crystal structure of human cholesterol sulfotransferase (SULT2B1b) in the presence of pregnenolone and 3'phosphoadenosine 5'-phosphate. Rationale for specificity differences between prototypical SULT2A1 and the SULT2BG1 isoforms. J Biol Chem. 2003 Nov 7;278(45):44593-9.

Levine, $\mathrm{M}$ and Tarver, H. Studies on ethionine. III. Incorporation of ethionine into rat proteins. J. Biol. Chem., 1951;192, 835

Lewis BP, Green RE, Brenner SE. Evidence for the widespread coupling of alternative splicing and nonsense-mediated mRNA decay in humans. Proc Natl Acad Sci U S A. 2003 Jan 7;100(1):189-92

Loraine AE, Helt GA, Cline MS, Siani-Rose MA. Exploring alternative transcript structure in the human genome using blocks and InterPro. J Bioinform Comput Biol. 2003 Jul;1(2):289-306

Magen A, Ast $\mathrm{G}$ The importance of being divisible by three in alternative splicing. Nucleic Acids Res. 2005 Sep 28;33(17):5574-82.

Mercatante D, Kole R. Modification of alternative splicing pathways as a potential approach to chemotherapy. Pharmacol Ther. 2000 Mar;85(3):237-43. 
Milanesi L, Petrillo M, Sepe L, Boccia A, D'Agostino N, Passamano M, Di Nardo S, Tasco $\underline{\mathrm{G}}$, Casadio R, Paolella G Systematic analysis of human kinase genes: a large number of genes and alternative splicing events result in functional and structural diversity. BMC Bioinformatics. 2005 Dec 1;6 Suppl 4:S20

Modrek B, Resch A, Grasso C, Lee C. Genome-wide detection of alternative splicing in expressed sequences of human genes. Nucleic Acids Res. 2001 Jul 1;29(13):2850-9

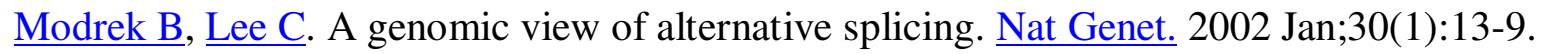

Mount DW Bioinformatics: Sequence and Genome Analysis,Cold Spring Harbor, NY: Cold Spring Harbor Laboratory Press, 2004

Mount SM. Genomic sequence, splicing, and gene annotation. Am J Hum Genet. 2000 Oct;67(4):788-92

Murzin AG, Brenner SE, Hubbard T, Chothia C. SCOP: a structural classification of proteins database for the investigation of sequences and structures. J Mol Biol. $1995 \mathrm{Apr}$ 7;247(4):536-40.

Nagano N, Orengo CA, Thornton JM. One fold with many functions: the evolutionary relationships between TIM barrel families based on their sequences, structures and functions. J Mol Biol. 2002 Aug 30;321(5):741-65.

Newman A. Small nuclear RNAs and pre-mRNA splicing. Curr Opin Cell Biol. 1994 Jun;6(3):360-7.

Nilsen TW. The spliceosome: the most complex macromolecular machine in the cell? Bioessays. 2003 Dec;25(12):1147-9

Oakley AJ, Harnnoi T, Udomsinprasert R, Jirajaroenrat K, Ketterman AJ, Wilce MC. The crystal structures of glutathione S-transferases isozymes 1-3 and 1-4 from Anopheles dirus species B. Protein Sci. 2001 Nov;10(11):2176-85.

Offman MN, Nurtdinov RN, Gelfand MS, Frishman D. No statistical support for correlation between the positions of protein interaction sites and alternatively spliced regions. BMC Bioinformatics. 2004 Apr 19;5:41.

Okazaki Y, Furuno M, Kasukawa T, Adachi J, Bono H, Kondo S, Nikaido I, et al Analysis of the mouse transcriptome based on functional annotation of 60,770 full-length cDNAs. Nature. 2002 Dec 5;420(6915):563-73

Orengo CA, Michie AD, Jones S, Jones DT, Swindells MB, Thornton JM. CATH-A Hierarchic Classification of Protein Domain Structures. Structure 1997, 5:1093-1108.

Pauling L, Corey RB. Configuration of polypeptide chains. Nature. 1951 Sep 29;168(4274):550-1 
Pearson H. Genetics: what is a gene? Nature. 2006 May 25;441(7092):398-401

Peneff C, Ferrari P, Charrier V, Taburet Y, Monnier C, Zamboni V, Winter J, Harnois M, Fassy F, Bourne Y. Crystal structures of two human pyrophosphorylase isoforms in complexes with UDPGlc(Gal)NAc: role of the alternatively spliced insert in the enzyme oligomeric assembly and active site architecture. EMBO J. 2001 Nov 15;20(22):6191-202.

Pontius JU, Wagner L, Schuler GD. UniGene: a unified view of the transcriptome. In: The NCBI Handbook. Bethesda (MD): National Center for Biotechnology Information; 2003.

Quackenbush J, Liang F, Holt I, Pertea G, Upton J. The TIGR gene indices: reconstruction and representation of expressed gene sequences. Nucleic Acids Res. 2000 Jan 1;28(1):1415 .

Radivojac P, Obradovic Z, Brown CJ, Dunker AK. Improving sequence alignments for intrinsically disordered proteins. Pac Symp Biocomput. 2002;:589-600.

Reed R. Mechanisms of fidelity in pre-mRNA splicing. Curr Opin Cell Biol. 2000 Jun;12(3):340-5

$\underline{\text { Roca X }}, \underline{\text { Sachidanandam R, }}$ Krainer AR. Intrinsic differences between authentic and cryptic 5' splice sites. Nucleic Acids Res. 2003 Nov 1;31(21):6321-33

Romero PR, Zaidi S, Fang YY, Uversky VN, Radivojac P, Oldfield CJ, Cortese MS,

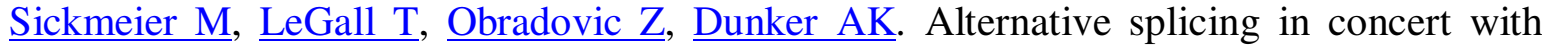
protein intrinsic disorder enables increased functional diversity in multicellular organisms. Proc Natl Acad Sci U S A. 2006 May 30;103(22):8390-5.

Rose GD, Fleming PJ, Banavar JR, Maritan A. A backbone-based theory of protein folding. Proc Natl Acad Sci U S A. 2006 Nov 7;103(45):16623-33.

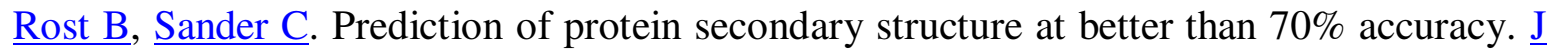
Mol Biol. 1993 Jul 20;232(2):584-99.

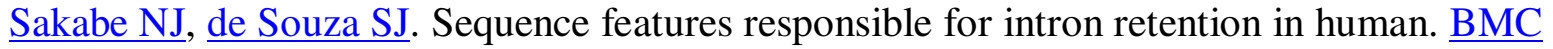
Genomics. 2007 Feb 26;8:59

Sanger F, Air GM, Barrell BG, Brown NL, Coulson AR, Fiddes CA, Hutchison CA, Slocombe PM, Smith M. Nucleotide sequence of bacteriophage phi X174 DNA.Nature. 1977 Feb 24;265(5596):687-95.

Sayle RA, Milner-White EJ. RASMOL: biomolecular graphics for all. Trends Biochem Sci. 1995 Sep;20(9):374.

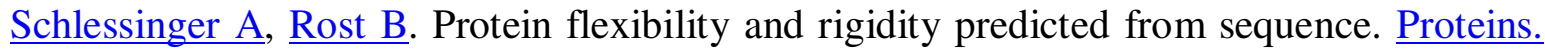
2005 Oct 1;61(1):115-26. 
Schlessinger A, Yachdav G, Rost B. PROFbval: predict flexible and rigid residues in proteins. Bioinformatics. 2006 Apr 1;22(7):891-3.

Schmid FX, Layr LM, Mücke M and Schönbrunner ER. Prolyl Isomerases: Role in Protein Folding. Adv. Protein Chem. (1993) 44, 25-66

Selkoe DJ. Folding proteins in fatal ways. Nature. 2003 Dec 18;426(6968):900-4.

Senapathy $\mathrm{P}, \underline{\text { Shapiro MB}}$ Harris NL Splice junctions, branch point sites, and exons: sequence statistics, identification, and applications to genome project. Methods Enzymol. 1990;183:252-78.

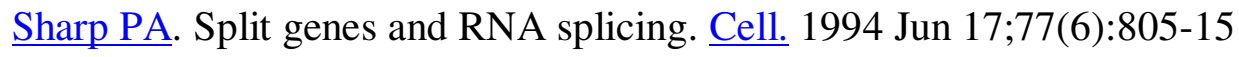

Sorek R, Shamir R, Ast G How prevalent is functional alternative splicing in the human genome? Trends Genet. $2004 \mathrm{Feb}$;20(2):68-71

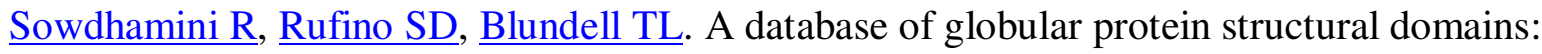
clustering of representative family members into similar folds. Fold Des. 1996;1(3):209-20

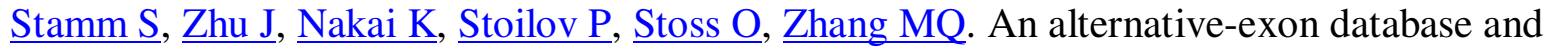
its statistical analysis. DNA Cell Biol. 2000 Dec;19(12):739-56

Stetefeld J, Alexandrescu AT, Maciejewski MW, Jenny M, Rathgeb-Szabo K, Schulthess $\underline{T}$, Landwehr R, Frank S, Ruegg MA, Kammerer RA. Modulation of agrin function by alternative splicing and Ca2+ binding. Structure. 2004 Mar;12(3):503-15.

Stetefeld J, Ruegg MA Structural and functional diversity generated by alternative mRNA splicing. Trends Biochem Sci. 2005 Sep;30(9):515-21

Stockklausner C, Breit S, Neu-Yilik G, Echner N, Hentze MW, Kulozik AE, Gehring NH The uORF-containing thrombopoietin mRNA escapes nonsense-mediated decay (NMD). Nucleic Acids Res. 2006 May 5;34(8):2355-63

Teraoka SN, Telatar M, Becker-Catania S, Liang T, Onengüt S, Tolun A, Chessa L, Sanal $\underline{\mathrm{O}}$, Bernatowska E, Gatti RA, Concannon P. Splicing defects in the ataxia-telangiectasia gene, ATM: underlying mutations and consequences. Am J Hum Genet. 1999 Jun;64(6):1617-31

Tress ML, Martelli PL, Frankish A, Reeves GA, Wesselink JJ, Yeats C, Olason PL, Albrecht M, Hegyi H, Giorgetti A, Raimondo D, Lagarde J, Laskowski RA, López G,

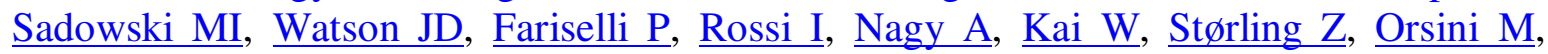
Assenov Y, Blankenburg H, Huthmacher C, Ramírez F, Schlicker A, Denoeud F, Jones P, Kerrien S, Orchard S, Antonarakis SE, Reymond A, Birney E, Brunak S, Casadio R, Guigo $\underline{\mathrm{R}}, \underline{\text { Harrow J}}, \underline{\text { Hermjakob H}}$, Jones DT, Lengauer T, Orengo CA, Patthy L, Thornton JM, 
Tramontano A, Valencia A. The implications of alternative splicing in the ENCODE protein complement. Proc Natl Acad Sci U S A. 2007 Mar 27;104(13):5495-500.

Venter JC et al, Celera Genomics, The sequence of the human genome. Science. 2001 Feb 16;291(5507):1304-51

Voigt CA, Martinez C, Wang ZG, Mayo SL, Arnold FH. Protein building blocks preserved by recombination. Nat Struct Biol. 2002 Jul;9(7):553-8

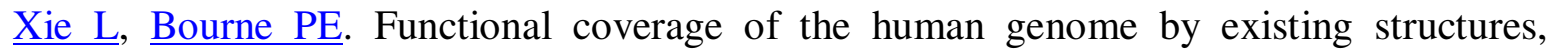
structural genomics targets, and homology models. PLoS Comput Biol. 2005 Aug;1(3):e31.

Xu Q, Lee C. Discovery of novel splice forms and functional analysis of cancer-specific alternative splicing in human expressed sequences. Nucleic Acids Res. 2003 Oct 1;31(19):5635-43.

Zavolan M, Kondo S, Schonbach C, Adachi J, Hume DA, Hayashizaki Y, Gaasterland T; RIKEN GER Group; GSL Members. Impact of alternative initiation, splicing, and termination on the diversity of the mRNA transcripts encoded by the mouse transcriptome. Genome Res. 2003 Jun;13(6B):1290-300.

Zhang J, Maquat LE. Evidence that translation reinitiation abrogates nonsense-mediated mRNA decay in mammalian cells. EMBO J. 1997 Feb 17;16(4):826-33

Zhuang YA, Goldstein AM, Weiner AM UACUAAC is the preferred branch site for mammalian mRNA splicing Proc Natl Acad Sci U S A. 1989 Apr;86(8):2752-6.

Yan Y, Moult J. Protein family clustering for structural genomics. J Mol Biol. 2005 Oct 28;353(3):744-59

$\underline{\text { Yura K}}$, Shionyu M, Hagino K, Hijikata A, Hirashima Y, Nakahara T, Eguchi T, Shinoda $\underline{\mathrm{K}}$, Yamaguchi A, Takahashi K, Itoh T, Imanishi T, Gojobori T, Go M. Alternative splicing in human transcriptome: functional and structural influence on proteins. Gene. 2006 Oct 1;380(2):63-71.

Wang $\mathrm{P}, \underline{\text { Yan } \mathrm{B}}$, Guo JT, Hicks $\mathrm{C}, \underline{\mathrm{Xu} \mathrm{Y}}$ Structural genomics analysis of alternative splicing and application to isoform structure modeling. Proc Natl Acad Sci U S A. 2005 Dec 27;102(52):18920-5

Watson JD, Crick FH. The structure of DNA. Cold Spring Harb Symp Quant Biol. 1953;18:123-31

Woodley L, Valcárcel J. Regulation of alternative pre-mRNA splicing. Brief Funct Genomic Proteomic. 2002 Oct;1(3):266-77 